\title{
LINGUAGENS HUMANAS: UMA AÇÃO DE EXPRESSÃO
}

VOLUME II

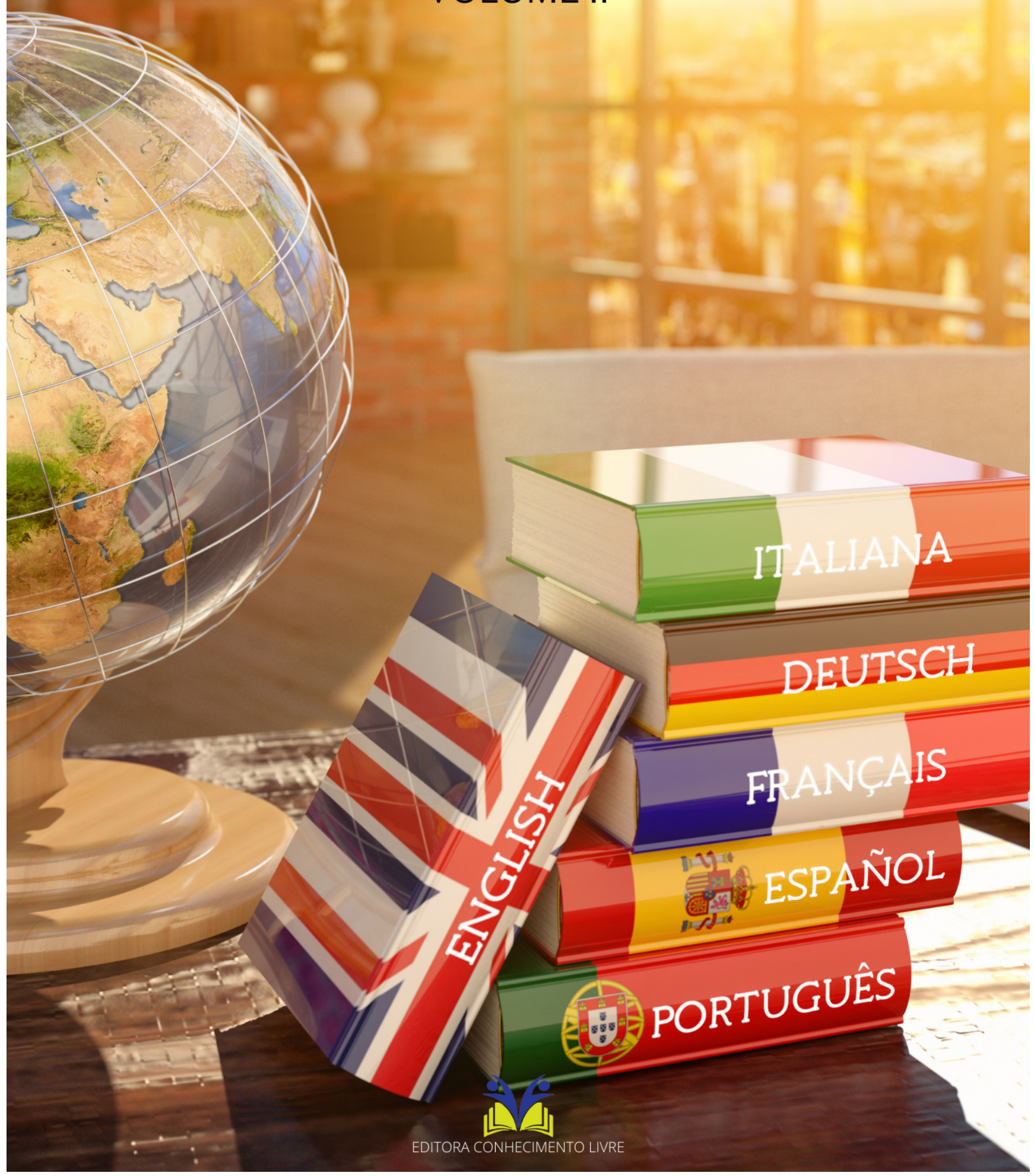


Frederico Celestino Barbosa

Linguagens humanas uma ação de expressão

$1^{\text {a }}$ ed.

Piracanjuba-GO

Editora Conhecimento Livre

Piracanjuba-GO 
$1^{\mathrm{a}} \mathrm{ed}$

\section{Dados Internacionais de Catalogação na Publicação (CIP)}

Barbosa, Frederico Celestino

B238L Linguagens humanas uma ação de expressão

/ Frederico Celestino Barbosa. - Piracanjuba-GO

Editora Conhecimento Livre, 2021

102 f.: il

DOI: $10.37423 / 2021$.edcl 281

ISBN: 978-65-89955-34-4

Modo de acesso: World Wide Web

Incluir Bibliografia

1. línguas 2. teatro 3. cinema 4. linguística 5. arte I. Barbosa, Frederico Celestino II. Título

CDU: 400

https://doi.org/10.37423/2021.edc1281

O conteúdo dos artigos e sua correção ortográfica são de responsabilidade exclusiva dos seus respectivos autores. 


\title{
EDITORA CONHECIMENTO LIVRE
}

\section{Corpo Editorial}

\author{
Dr. João Luís Ribeiro Ulhôa \\ Dra. Eyde Cristianne Saraiva-Bonatto \\ Dr. Anderson Reis de Sousa \\ MSc. Frederico Celestino Barbosa \\ MSc. Carlos Eduardo de Oliveira Gontijo
}

$\underline{\text { MSc. Plínio Ferreira Pires }}$

Editora Conhecimento Livre

Piracanjuba-GO 


\section{SUMÁRIO}

CAPÍTULO 1 5

PACIENTE COM DIAGNÓSTICO DE AFASIA, CONSEQUÊNCIA DE AVC ISQUÊMICO

TRATADO ATRAVÉS DA MÚSICA

CLECIO CARLOS GOMES

DOI 10.37423/210604241

CAPÍTULO 2 18

GÊNERO TEXTUAL- USO DAS VARÍAVEIS DE TRADUÇÕES MUSICAIS NO ENSINO DA

LÍNGUA INGLESA

Izadora Cabral de Cerqueira

Jean Marcelo Barbosa de Oliveira

DOI 10.37423/210604336

CAPÍTULO 3

ANÁLISE LINGUÍSTICA DA MORFOLÓGICA EM LIBRAS: OS TRÊS PROCESSOS DE

FORMAÇÃO DOS SINAIS

RIVAEL MATEUS FABRICIO

FRANCIELI GIZA

DOI 10.37423/210604358

CAPÍTULO 4 36 LIVRO DE ARTISTA COMO AÇÃO ARTE-DESIGN EDUCATIVA NO CONTEXTO DA INCLUSÃO SOCIAL

NILDA SILVA DE OLIVEIRA

DOI 10.37423/210604364

CAPÍTULO 5 53

ANÁLISE DO PRIMEIRO MOVIMENTO DA SONATINA PARA FLAUTA E VIOLÃO DE RADAMÉS GNATALLI

Raissa Anastasia de Souza Melo

DOI 10.37423/210604379

CAPÍTULO 6

A TEMPESTADE: O TEATRO POLÍTICO DE AUGUSTO BOAL

ADALMIR DE MIRANDA MOURA

DOI 10.37423/210604408 
LÍNGUA ESTRANGEIRA, CURRÍCULO E MOTIVAÇÃO DOCENTE: UMA ANÁLISE DA

PERCEPÇÃO DE ENSINO DE INGLÊS NOS ANOS FINAIS DO ENSINO FUNDAMENTAL

Rackel Peralva Menezes Vasconcellos

Poliana Campos Côrtes Luna

Lucas Capita Quarto

Cristiana Barcelos da Silva

Carlos Henrique Medeiros de Souza

Maria Eliza Guimarães Tavares

Cristina Pereira Gomes de Azeredo

DOI 10.37423/210704419

CAPÍTULO 8

90

UMA ANÁLISE DAS CRÔNICAS DE AUTORIA DE MARTHA MEDEIROS E LYA LUFT SOBRE A MULHER CONTEMPORÂNEA

GIOVANNA DE ARAÚJO LEITE

DOI 10.37423/210704437 


\section{Capítulo 1}

doi $10.37423 / 210604241$

PACIENTE COM DIAGNÓSTICO DE AFASIA, CONSEQUÊNCIA DE AVC ISQUÊMICO TRATADO ATRAVÉS DA MÚSICA 
Resumo: Relata-se o caso de uma criança de 11 anos e 8 meses, diagnosticada, aos 6 meses de idade, com Acidente Vascular Cerebral (AVC) isquêmico, $3,8 \mathrm{~cm}$, no hemisfério esquerdo, região do lobo frontal, com visível comprometimento da área de Broca. Consequentemente, teve como comorbidade afasia, com prejuízo significativo no processamento auditivo. A fim de promover o desenvolvimento da linguagem, criou-se um protocolo terapêutico embasado na ortografia e na execução de música. Aplicaram-se notas isoladas, arpejos e variações, com solfejo das notas, para assim buscar a proximidade com o processo de comunicação. A criança passou a falar e a ter um processamento auditivo funcional.

Palavras-chave: NEUROCIÊNCIA, MÚSICA, LINGUAGEM, AFASIA 


\section{O PACIENTE}

Lé o sujeito do caso do estudo de caso descrito nesse artigo. Criança do gênero masculino, nascido de uma gestação gemelar, prematuramente, aos 7 meses de gravidez. Resposta positiva aos exames protocolados ao nascimento e permanência por 21 anos em UTI neonatal, sem patologia médica associada, apenas para maturação geral como prematuro. Após a saída da maternidade, L mantinha uma saúde compatível com os critérios pediátricos, contudo, mantinha um comportamento que chamava à atenção: chorava praticamente o dia e a noite toda, dormindo muito pouco.

Em torno de seis meses de idade foi internado com uma crise aguda de bronquite. Na ocasião, passando por um procedimento fisioterápico respiratório, a profissional percebeu uma alteração na movimentação do braço direito de L. Os pais foram avisados e então se recomendou uma avaliação para um diagnóstico diferencial. L foi submetido a um exame por imagem, Tomografia Computadorizada (TC) de crânio. A conclusão diagnóstica apontou que L passara por um Acidente Vascular Cerebral (AVC) isquêmico, provavelmente em período perinatal, envolvendo a profundidade e a ínsula esquerda, no sulco lateral entre o Lobo Frontal e Parietal, com alterações sequelares retráteis nas proximidades e evidências de degeneração walleriana envolvendo o pedúnculo cerebral esquerdo. Provável afetação na área de Broca e Wernicke.

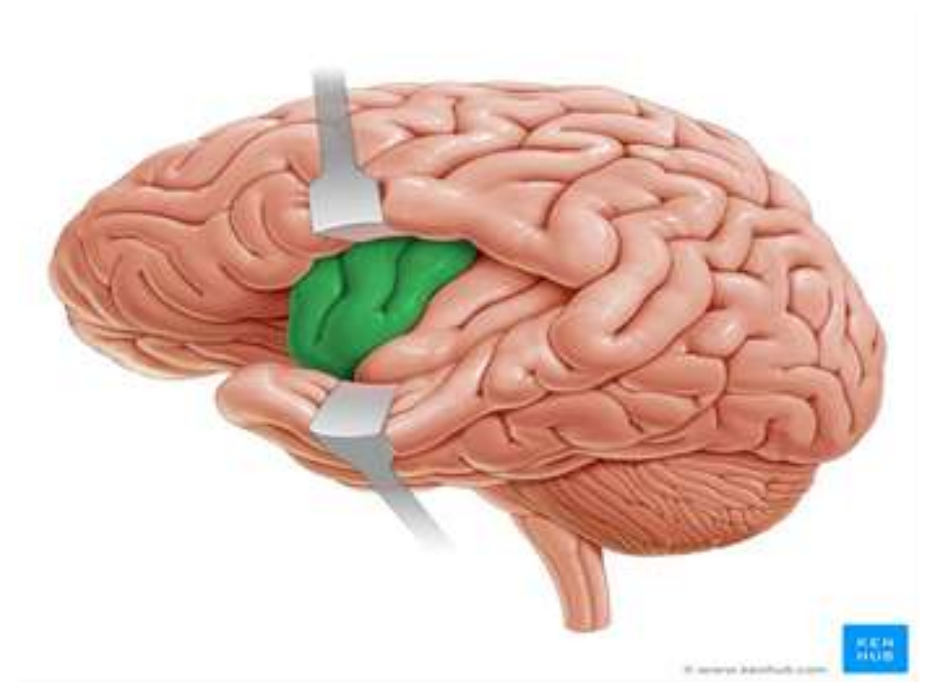

Fonte: Kenhub

Encaminhado à Neuropediatria, L é tem o prognóstico de um prejuízo motor significativo, amplo e fino, levando a impossibilidade para caminhar. Retardo mental de moderado a severo, dano severo nos processos de linguagem, palavra falada e processamento auditivo. Essas impressões foram 
traduzidas por diferentes especialistas. A Afasia, especificamente, foi consolidada por um professional, Fonoaudiólogo, reconhecido no cenário nacional e internacional.

A partir dessa constatação, inicia-se uma peregrinação junto aos serviços da saúde para oferecer tratamento e com isso tentar promover algum tipo de qualidade de vida para L. Mesmo com a sequência de consultas, avaliações terapias, L, depois de quatros anos, recebe o diagnóstico de Epilepsia tipo pequeno mal, que justificava o fato de chorar boa parte do dia e da noite, com episódios de sono com curta duração nesses seus primeiros anos de vida. A introdução dos anticonvulsionantes desencadeou a síndrome de |Stevens Johnson que fez L evoluir para a UTI e quase óbito.

Entre as várias respostas funcionais afetadas, a Afasia e o Déficit do Processamento Auditivo representaram um dos focos de preocupação dos pais, afinal como seria para $L$ não se comunicar tendo, supostamente, tantas limitações o acompanhando nas atividades da vida diária.

Diante desse preocupante cenário, perspectivas negativas emergiram. O medo, a insegurança e vários outros sentimentos negativos brotavam frente a uma perspectiva no mínimo desconhecida. Entretanto, um insight surge: L sempre manifestava incômodo quando seu pai, tocando violino, desafinava alguma nota. A música vem ao encontro dessas pessoas, desse quadro, e uma mínima expectativa aparece.

\section{LINGUAGEM E AFASIA}

Ouvir é um processo que envolve elementos mecânicos, suas partes anatômicas que captam e conduzem a vibração sonora para o cérebro interpretá-la nas áreas de Broca e de Wernicke, realizando o processamento auditivo (GUYTON, 2006).

Importante elemento para a audição é o qualitativo, ou seja, a habilidade de construir uma compreensão sobre o estímulo recebido, dando a este um significado emocional e cognitivo, associando à infinidade de registros mnemônicos acomodados junto ao banco de memória que cada indivíduo possui, possibilitando a análise e o entendimento do mundo externo e da subjetividade (PEREIRA, REUS \& MAGALHÃES, 2003).

A linguagem é predominante, independentemente de sua estruturação no processo de desenvolvimento, logo, o som é parte constituinte do processamento auditivo, estabelecendo o padrão acima citado. Já a fala, essa desdobra-se pelo viés da audição e ai se produz, igualmente, pela mecânica fonoarticulatória (PEREIRA, REUS \& MAGALHÃES, 2003). 
A linguagem é uma das funções mentais mais relevantes. Justifica-se pelo fato de dar significado, expressar e estabelecer a ligação com o próprio indivíduo, com as pessoas nos grupos sociais e com as coisas. A linguagem, em sua essência, possibilita a separação do eu e do outro, alicerçando o pensamento, sua expressão até o alcance da troca e da socialização. A funcionalidade individual e coletiva desdobra-se a partir dai. Qualitativamente, a linguagem permite a elaboração criativa e subjetiva através da projeção artística (DALGALARRONDO, 2000).

As pesquisas mostram que há uma tendência maior de a linguagem ser processada no hemisfério esquerdo. Tanto o estímulo visual como o auditivo, de caráter linguístico, são processados nessa parte do cérebro. Elementos fonéticos, palavras e frases e, parte da prosódia, circuitam do lado esquerdo. A área de Broca organiza e planeja a linguagem e a área de Wernicke significa (KANDEL, 2014).

A Afasia é um transtorno da linguagem e se caracteriza pela perda, parcial ou total, da habilidade em compreender e expressar a linguagem. A etiologia é de causa orgânica, consequente de lesão nas áreas cerebrais responsáveis pela resposta comunicativa. O AVC é u quadro mais comum para o surgimento da resposta afásica, já que a maioria das incidências se dá na região tempo-parietal. Na Afasia de Broca , o indivíduo compreende mas não consegue expressar a linguagem., Quando é do tipo de Wernicke, é o oposto, a pessoa fala mas não consegue entender. Por fim, a global é caracteriza por não conseguir falar e nem alcançar o devido entendimento (MEIER et all, 2019).

Há uma alteração funcional nos centros da linguagem na região do córtex cerebral e núcleos da base, predominantemente, no hemisfério esquerdo. A parte inferoposterior do lobo frontal onde se localiza a área de Broca e posterosuperior no lobo temporal, onde se situa a área de Wernicke são responsáveis pelo processamento da linguagem. A porção inferior do lobo parietal e as conexões subcorticais para essas regiões igualmente contribuem para a execução de linguagem. Qualquer tipo de lesão na anatomia descrita pode levar a disfuncionalidade da função mental da linguagem (COUDRY, 2008).

O processamento auditivo, por sua vez, é caracterizado pela inabilidade parcial, ou total, de entender aquilo que se ouve. Em alguns casos e situações, o indivíduo não reconhece o estímulo auditivo plenamente. É como se a estimulação sonora chegasse ao ouvido, mas sua decodificação pelo encéfalo fosse incompleta ou nula. Muitas pessoas são definidas como desatentas, até mesmo mal-educadas, porém, a justificativa se encontra em uma disfunção fonoaudiológica que gera sofrimento para o paciente. Complicações gestacionais, desordens genéticas, doenças infectocontagiosas, anóxia ou traumas durante o parto e traumas crânio encefálicos podem produzir alterações no aparelho 
auditivo, da recepção a emissão elétrica para o encéfalo, alterando a capacidade do processamento auditivo (VIEIRA, 2007).

\section{MÚSICA E NEUROCIÊNCIA}

A onda sonora que representa a música é acolhida pelo ouvido, conduzida pelas células ciliadas e adentra o cérebro em forma de estímulos elétricos. Essa sonorização transita, com marcação maior, no hemisfério direito, porém, faz passagem pelo esquerdo. Sua propagação não é específica, já que estimula diferentes áreas cerebrais. A música é independente pois é executada de forma diferente ao da linguagem, ou seja, a música tem vida própria, mesmo coadunando-se com os símbolos gráficos da linguagem falada e escrita (PERETEZ \&ZATORRE, 2003).

Pesquisadores revelam que a aplicação da música em diferentes neuropatologias alcança uma resolutividade positiva, agregando significativamente às terapêuticas tradicionais e gerando uma expectativa de melhor qualidade de vida para os doentes. Doenças crônicas e degenerativas tendo seus critérios de diagnóstico reduzidos e, em alguns casos, interrompidos. Outros quadros emocionais e comportamentais, com intensidade e comprometimento menores, estão sendo igualmente tratadas dentro do protocolo da estimulação musical e a resolutividade é, igualmente, positiva (ROJO at all, 2011).

Além desse aspecto terapêutico, verificam-se alterações funcionais e anatômicas em áreas cerebrais de músicos profissionais quando em comparação a músicos amadores e a apreciadores da música. Cerebelo com número maior de arborização dos dendritos, corpo caloso com ramificação mais intensa, conexões entre hemisfério esquerdo e direito, potencializando áreas da linguagem. É a música agindo sobre o potencial de transmutação anátomo fisiológico do Encéfalo humano (ABDUL-KAREN at all, 2011).

A música, estruturada pelo ritmo, a melodia, sua altura, a velocidade e intensidade, estimula tudo o que habita o hiato, o que não está disponível à consciência, desloca, processa e redireciona a condição que se encontra. A música interrompe o direcionamento das árvores dendríticas e as reconduz. Logo, aquilo que encontrava-se disfuncional ou mal adaptativo, readéqua e reinicia a forma funcional para direcionar a atenção, qualificar os dados de memória, fazer pensar diferente e dar outro padrão para a solução dos problemas, usando a inteligência de uma maneira mais apropriada (THOARIA et all, 2014 \& LEÃO, 2005 \& LI, 2010). 
O perfil da música, ausente de semântica, permite a desprogramação de definições fechadas, anula referências consolidadas, tanto as psicológicas como a neurológicas, e dá diversidade às crenças engessadas. Isso da mobilidade para o funcionamento mental, dá sustentação para a relação de causa e consequência do fenômeno vida e, efetivamente, então, lança luz à consciência acerca daquilo que se faz desconhecido na própria identidade.

\section{A TEORIZAÇÃO DO MÉTODO}

A construção do método surge da associação de três elementos: o arcabouço originado da semiologia da Psicopatologia cuja essência é consolidada através da compreensão das funções mentais; das noções teóricas da música, uma das formas de linguagem que atua em amplas e diferentes regiões cerebrais e um dos principais meios de promoção de plasticidade e, finalmente, talvez o fator mais relevante, ser pai dessa criança que se transformou em um estudo de caso.

Meu filho recebera um prognóstico sombrio, com graves limitações físicas e uma perspectiva de qualidade de vida bem prejudicada. Associado a esse quadro, ele também não falaria, ou seja, não conseguiria expressar para mim, sua mãe, irmãos, para o mundo, suas alegrias, necessidades. Eu não podia permitir isso e meu método foi associar tudo o que estudei ao amor que tinha por ele para ajudá-lo. Não tive referenciais bibliográficos, nem orientadores. Eu tinha o tempo que travava uma guerra contra meu filho: ele precisava ser estimulado o auge de seu processo de desenvolvimento e assim ter êxito.

Sendo a música uma forma de linguagem que age na orquestração de todas as funções mentais e comunica, faria meu filho falar fazendo da música seu idioma nativo, usando outras estruturas cerebrais, compensando as regiões lesionadas pelo AVC, responsáveis pela linguagem.

\section{Localização da Fonte Sonora:}

Através da função mental da atenção, o indivíduo exerce a habilidade de identificar os sons em seu ambiente, especificando sua escuta, ou generalizando. Falamos em focar em um estímulo auditivo específico, ou, percebendo estímulos diferenciados em um mesmo intervalo espaço e tempo (MALLOY-DINIS at all, 2016).

Cada escala musical, bem como as notas que a compõe, vibra em frequências diferenciadas, estimulando ondas elétricas cerebrais, diferentes e em regiões anatômicas alternadas. Conscientes ou não destes estímulos, o processo perceptivo acontecerá da mesma forma. Através de um 
procedimento organizado, pedagógico e focado na plasticidade, o terapeuta passa a ter a possibilidade de potencializar e de estruturar o funcionamento sensorial e mental do paciente.

A capacidade para distingui-las, permite o desenvolvimento da ação espaço cerebral, com a devida localização para seu funcionamento e papel sistêmico no organismo .

\section{Memória Sequencial:}

Memória é a capacidade do indivíduo de reter, fixar e evocar dados mnemônicos, ou estímulos externos e internos, captados pela percepção e conduzi-los ao processamento do Sistema Nervoso Central. O pensamento é o conjunto de conteúdos estruturados, por identificação de valores e de símbolos. Já a inteligência entra com a capacidade analítica que a pessoa tem para processar estes conteúdos. Observa-se, assim, a integração natural e direta destas três funções mentais para a concretização deste processo (DALGALARRONDO, 200).

Sequencial é definida por contínua, sucessão, encadeamento. A memória sequencial no processo de escuta, associado à música, permite o desenvolvimento das habilidades citadas, dado ao espaço cerebral e sua efetiva definição.

\section{Fechamento Auditivo:}

O fechamento auditivo está relacionado à capacidade psicológica,

fonoaudiológica e neurológica de agregar, complementar ou associar, de acordo com a realidade interna, um estímulo incompleto, dando a este o devido significado.

Desta forma, elenca-se um ciclo essencial ao processo sensorial para a audição, onde indivíduo habilita-se no reconhecimento de semelhanças e diferenças em relação ao som percebido e a consequente discriminação através da construção de significados e de símbolos. Para a realização completa deste, o aparelho auditivo precisa estar íntegro, ou parcialmente capacitado para o auxílio básico, e as demais funções mentais orquestradas e em homeostase para sua efetivação. Novamente, a interligação entre o elemento mecânico e o qualitativo (KIMA et all, 20190)

\section{Figura e Fundo:}

O processo de figura e fundo está atrelado, diretamente, à percepção da pessoa e sua respectiva capacidade em captar os estímulos do meio. A percepção pode ocorrer de forma consciente ou não, independentemente disso, acontecerá. É dinâmico e contínuo visto as infinitas possibilidades criadas 
na relação entre a subjetividade do ser e sua relação com o meio. Na verdade, incontáveis alternativas para encontros, para a comunicação e a compreensão do todo.

O homem, como ser pluralizado, dá o significado aos estímulos recebidos de acordo com sua carta de valores e sua realidade interna, definindo-os através do seu livre arbítrio. Em relação ao som, muitas pessoas, a maioria das vezes apresentam dificuldade em estabelecer a diferença entre a estrutura que enquadra uma figura principal. Aqui não falamos apenas de melodias, peças ou canções, generalizamos o estímulo auditivo, onde nem sempre há uma capacidade em distinguir e associar um conjunto de sons, decodificando-os (FLORY \& RAMOZZI-CHIAROTTINO, 2006)

\section{Análise e Síntese:}

A análise percebe, avalia e decompõe a estrutura global. A síntese, opostamente, observa e interage com as partes do grande todo. Ao longo de todos estes exercícios, uma percepção genérica do som, básico, emitido, pelo violino, é repassado ao paciente com o objetivo de estimulá-lo a um processo saudável de escutação para todas as grandes áreas da sua vida.

Com novos exercícios, vamos medir como essa percepção foi desenvolvida e quais as necessidades de aprimoramento dentro do processo (SALLES, 2010).

\section{O CONTEXTO EXPERIMENTAL DO MÉTODO}

L. tinha 2 anos e 10 meses quando o protocolo começou a ser aplicado. Sua expressão de linguagem verbal era inexistente quando comparado ao grupo da mesma faixa etária de desenvolvimento. Chorava, eminentemente. A habilidade de imitação era restrita e limitada.

As atividades musicais foram todas conduzidas com instrumento de corda, o violino. Cada execução, independentemente do nível de evolução dos exercícios propostos, era sempre acompanhada da ação de solfejar as notas. Solfejar é a ação de cantar as notas emitidas pelo instrumento musical. As tarefas sempre eram realizadas com $L$ deitado e o pé do instrumentista sobre a barriga dele fazendo o ritmo. finalidade era associar a fonética semântica da linguagem (hemisfério esquerdo) com a estrutura musical para compensar a lesão e promover a linguagem através de outro idioma, no caso a música.

\section{Atividade Propostas:}

- Identificando a musicalidade de cada corda do violino:

Provocar a distinção de cada som, o solfejo fonético e o ritmo.

- $\quad$ Mi (1a corda do instrumento); 
La (2 2 corda do instrumento);

$\operatorname{Re}\left(3^{\text {a }}\right.$ corda do instrumento);

Sol (4a corda do instrumento);

- Identificando as Oitavas:

Ampliar a informação fonética através do solfejo, com diferentes notas musicais. Formar palavras com as sílabas das notas e trabalhar a frequência nas diferentes oitavas

Mi, Fa, Sol, La, Si, Do, Re (1a corda do instrumento);

$\mathrm{La}, \mathrm{Si}, \mathrm{Do}, \mathrm{Re}, \mathrm{Mi}, \mathrm{Fa}$, Sol (2ª corda do instrumento);

Re, Mi, Fa, Sol, La, Si, Do (3a corda do instrumento);

Sol, La, Si, Do, Re, Mi, Fa (4a corda do instrumento);

- Apresentação da Peça Estrelinha, de Suzuki, associando as notas da $1^{\underline{a}}$ e da $2^{\underline{a}}$ corda

Nessa etapa foi trabalhado escalas diferentes, estimulando a percepção de alturas diferentes, estimulando atenção e fomentando a memória. Também a peça era tocada em oitavas diferentes, provocando novas percepções, e ampliação do processo de atenção e de ondulação da sonorização

La, La, La, La (2 a corda do instrumento);

$\mathrm{Mi}, \mathrm{Mi}, \mathrm{Mi}, \mathrm{Mi}-\mathrm{Fa}, \mathrm{Fa}, \mathrm{Fa}, \mathrm{Fa}-\mathrm{Mi}, \mathrm{Mi}, \mathrm{Mi}, \mathrm{Mi}$ (1aㅡ corda do instrumento);

Re, Re, Re, Re - Do, Do, Do, Do - Si, Si, Si, Si - La, La, La, La (2a corda do instrumento);

$\mathrm{Mi}, \mathrm{Mi}, \mathrm{Mi}, \mathrm{Mi}-\mathrm{Fa}, \mathrm{Fa}, \mathrm{Fa}, \mathrm{Fa}-\mathrm{Mi}, \mathrm{Mi}, \mathrm{Mi}, \mathrm{Mi}$ (1a corda do instrumento)

- Associação a sequência de escala de notas de cada corda, com acordes de piano

Essa última etapa, empiricamente, pensou-se em socialização, fundamento da comunicação. Apresentou-se a relação do piano e do violino como analogia para o encontro entre pessoas. Diferentes sons, em timbres e ritmos iguais, executando a mesma melodia, falando um mesmo idioma.

- Mi, Fa, Sol, La, Si, Do, Re (1a corda do instrumento), com piano associado;

- La, Si, Do, Re, Mi, Fa, Sol (2a corda do instrumento) com piano associado;

- Re, Mi, Fa, Sol, La, Si, Do (3a corda do instrumento) com piano associado;

- Sol, La, Si, Do, Re, Mi, Fa (4⿳a corda do instrumento) com piano associado; 


\section{DISCUSSÃO}

O protocolo foi aplicado por um período de 08 meses, diariamente. Cada atividade era executada com violino e, simultaneamente, solfejada. A finalidade era a de possibilitar a pronúncia, linguagem verbal, de cada nota, estimulando a emissão silábica para aí formar palavras com as notas musicais e a posterior elaboração de frases simples. Ao longo do dia estimulava-se a criança com peças clássicas, tendo a música Brilha, Brilha Estrelinha, repetições periódicas. Inicialmente, as atividades eram executadas com a criança deitada (ela não sentava ainda) e o pé sobre sua barriga, ditando o ritmo do exercício. Uma forma de fazer com que esse elemento musical auxiliasse na tradução para a linguagem convencional.

L, então, passou a falar as notas, num primeiro momento com contornos musicais, até chegar ao padrão da comunicação verbal. Em seguida, incorporou palavras pequenas ao seu vocabulário, às mais complexas e frases. L então, após 08 meses de aplicação do protocolo, passou a expressar a linguagem verbal de forma adequada, falava palavras, frases e passou a interpretar os processos semânticos da comunicação coloquial. Passou pelo processo inicial da leitura na escola e conseguiu estabelecer a junção do processo verbal e não verbal.

Hoje L está com 11 anos e 08 meses, frequenta a 6ạ série, tendo aprovações por mérito. Fala, lê e escreve, compreendendo e interpretando o conteúdo. Observa-se um raciocínio lógico preservado e seu quadro Epilético eliminado, sem o uso de anticonvulsivantes, pois o mesmo tem Síndrome de Stevens-Johnsons e não pode fazer uso de medicação.

Pesquisas realizadas nas últimas décadas, envolvendo música e neurociência, mostram as possibilidades para a obtenção de plasticidade e de recuperação de diferentes quadros neuropatológicos. Muito ainda precisa ser investigado e respondido, especificamente, como é que esse processo acontece no Sistema Nervoso Central (SNC) e até onde a expressão musical pode nos levar. O significativo é perceber a possibilidade de alento à qualidade de vida de um número significativo de indivíduos frente as suas disfunções e as possibilidades terapêuticas com menor impacto e redução de efeitos indesejados como ocorre com alguns procedimentos atuais.

\section{CONCLUSÃO}

Passaram-se, aproximadamente, oito anos da aplicação desse protocolo no paciente L. É certo que se sua execução acontecesse nos dias atuais, muitas estruturas seriam diferentes, assim como a própria 
fundamentação. Creio que um músico profissional, um Musicoterapeuta teria estruturado e definido de outra maneira e com mais qualidade.

Em verdade, $L$ se chama Lorenzo e essa construção foi conduzida por mim, seu pai. Na época, um pai que se desesperou e que queria, de qualquer forma, permitir que seu filho tivesse uma condição de vida digna, com qualidade. Afinal, eu e sua mão vamos morrer um dia. Eu não era nada, apenas pai do Lorenzo. Psicólogo de adultos, violinista amador que executava peças apenas para mim ... precisei sair desse mundo.

Sentir que Lorenzo ficava incomodado quando desafinava foi o passaporte para essa incrível jornada. Ter a noção de que as emoções moviam o mundo e que a música era um sentimento puro, os veículos. Meu desespero traduziu tudo isso em alguma coisa que nunca consegui definir muito bem, Afinal, era apenas pai.

Depois de tantas lutas, renúncias, de uma exaustão indescritível, eu, minha esposa, Betina, sua irmã gêmea, conseguimos oferecer para Lorenzo dignidade e qualidade de vida. Só aí eu pude construir um entendimento teórico e científico sobre tudo que aconteceu. Voltei a estudar, tornei-me Musicoterapeuta, Neurocientista e seguirei para Mestrado e Doutorado.

Por quê?! Para dar a pais e crianças alento para suas dores, porque dói, dói muito. Para gritar ao mundo que a música é um instrumento de auxílio fantástico para o cérebro que nem sempre reage a tudo o que a ciência ofereceu até agora. Para quebrar paradigmas. Para mostrar que podemos ser felizes.

Obrigado de todo coração. 


\section{REFERÊNCIA BIBLIOGRÁFICA}

Abdul-Kareem IA1, Stancak A, Parkes LM, Al-Ameen M, Alghamdi J, Aldhafeeri FM, Embleton K, Morris D, Sluming V. Plasticity of the Superior and Middle Cerebellar Peduncles in Musicians Revealed by Quantitative Analysis of Volume and Number of Streamlines Based on Diffusion Tensor Tractography. PubMed, 2011.

BRANCO, Ângela Uchoa. Crenças a Práticas Culturais: Co Construção e Ontogênese de Valores Sociais. Campinas, Periódicos Unicamp, 2006.

COUDRY, Maria Irma Hadler. Neurolinguistica Discursiva: Afasia como Tradução. Campinas. Uicamp Universidade de Campinas, 2008.

DALGALARRONDO, Paulo. Psicopatologia e Semiologia dos Transtornos Mentais. Porto Alegre, Artes Médicas, 2000.

FLORY, Elizabeth; RAMOZZI-CHAROTINO, Zélia. A Relação da Figura-Fundo e as Estruturas Infra-Lógicas na Construção da Identidade Psicossocial de Pessoas com Transtornos Severosdo CFomportamento. Boletim de Psicologia, 2006.

GUYTON \& HALL. Tratado de Fisiologia Médica. São Paulo, Elsevier Editora, 2017

https://www.kenhub.com/

KIMA, Kevin; ADAMSA, Luke; KEATORA, Lynsey M. ; SHEPPARDA, Shannon; BREININGA, Bonnie L.; RORDENB, Chris; FRIDRIKSSONC, Julius; BONILHAD, Leonardo; ROGALSKYE, Coriane; lovefg, Tracy; hichokh, Gregory; HILLISIA, Argye. Neural processing critical for distinguishing between speech sounds. Brain and Languafge, 2019.

MALLOY-DINIZ, Leandro; MATTOS, Paulo; ABREU, Neandre; FUENTES, Daniel. Neuropsicologia Clínica, Porto Alegre, 2016

MANNES, Elena. The Power of Music. US, 2011.

MARLEY, Iain. The Prehistory of Music. Oxford, Oxford Universsity Press, 2013

MEIER, Erin L.; JOHNSON, Jeffrey P.; PAN, Yue; KIRAN, Swathi. A Lesion and Connectivity-Based Hierarchical Model of Chronic Aphasia Recovery Dissociates Patients and Healthy Controls

Rojo N, Amengual J, Juncadella M, Rubio F, Camara E, Marco-Pallares J, Schneider S, Veciana M, Montero J, Mohammadi B, Altenmüller E, Grau C, Münte TF, Rodriguez-Fornells A. Music-Supported Therapy Induces Plasticity in the Sensorimotor Cortex in Chronic Stroke: a Single-Case Study Using Multimodal Imaging (fMRI-TMS). PUBmED, 2011.

SALLES, Sérgio de Souza. Análise e síntese lógica em Tomás de Aquino. Unicampp, 2010

VIEIRA, Patrícia Aguiar Cunha. Influência das Desordens de Processamento Auditivo na Avaliação Neuropsicológica de Pessoas com Dificuldade de Aprendizagem. Brasília. UnB - Universidade de Brasília, 2007. 


\section{Capítulo 2}

doi $10.37423 / 210604336$

GÊNERO TEXTUAL- USO DAS VARÍAVEIS DE TRADUÇÕES MUSICAIS NO ENSINO DA LÍNGUA INGLESA

Izadora Cabral de Cerqueira

Jean Marcelo Barbosa de Oliveira
UNIVERSIADE ESTADUA DE ALAGOAS CAMPUS PALMEIRA DOS ÍNDIOS

UNIVERSIADE ESTADUA DE ALAGOAS CAMPUS PALMEIRA DOS ÍNDIOS 
Resumo: Esse trabalho tem por intuito apresentar as várias formas de traduzir uma música dentro de sala de aula, usando linguagem regional, gírias e debates em sala para enriquecer o conhecimento e atiçar a curiosidade do aluno. A música escolhida: "If I were a boy" da cantora Beyonce, tem um tema e letra intrigante, que leva a debates diversos, dentre eles pode-se destacar o uso de gírias na tradução da música, bem como a forma regional e o linguajar antigo e as gírias gays.O referido trabalho tem como suporte teórico os PCNs (BRASIL, 2000) e Marcuschi (1998) e sua linha de raciocínio, a busca por diferentes maneiras de tradução de textos, levando o aluno ao interesse pelas diferentes formas de pensar e na interpretação de texto de uma língua diferente.

Palavras chave: Gênero Textual. Música. Tradução. Inglês. 


\section{INTRODUÇÃO}

As orientações apresentadas aqui têm como proposta um novo olhar para o uso de músicas na aprendizagem do inglês em sala de aula. Sabe-se o quão difícil é para adolescentes aceitarem uma nova língua e da necessidade de criar meios pelos quais se possa renovar a aquisição de línguas. A música é um dos gêneros textuais mais usados nas aulas de línguas.

Entretanto resumir as aulas à tradução da música pode "enxugar" demais as possibilidades de aprendizagem. A idéia é assimilar as expressões encontradas na música e trazê-las ao cotidiano, ao passado e aos grupos nacionais. As variáveis que ocorrem na língua portuguesa trazem diversos tipos de tradução para uma música. Essa exploração das variáveis pode atrair o aluno a novas concepções de tradução e ao entendimento lexical da língua inglesa.

Esse trabalho não prevê uma quebra do tradicional uso das músicas em sala de aula, mas uma reciclagem a partir das abordagens já prontas nas gramáticas, traz uma explanação do antigo, e da abordagem aos debates, incluindo também pesquisas de campo pela busca pelas variáveis e as formas de aquisição da linguagem por meio do entendimento da similaridade entre os brasileiros e os nativos da língua inglesa. É uma reciclagem do tradicional.

" [...] os novos conhecimentos introduzidos em determinada prática sociocultural ou determinada comunidade de prática entrarão numa interrelação com os conhecimentos já existentes. Nessa inter-relação entre o "novo" e o "velho", ambos se transformam, gerando conhecimentos "novos". Para que ele se torne um processo crítico e eficaz, é importante evitar, nessa interrelação, a mera importação do novo, sem promover a devida interação com o velho, por meio da qual tanto o recém-importado quanto o previamente existente se transformarão, criando algo novo." (BRASIL, 2006, p.109)

As perspectivas aqui apresentadas também visam um debate entre os jovens.

Visto que a música escolhida traz um tema ainda atual: "Olhar da mulher para o homem a atitudes sexistas"; a música "If I were a Boy" da cantora Beyoncé, envolve um debate que pode transformar certos comportamentos ainda não desenvolvidos pela sociedade brasileira. É importante ressaltas que nas aulas de acordo com as PCNs temos que trabalhar o lado cidadão do aluno:

"[...] a disciplina Línguas Estrangeiras na escola visa a ensinar um idioma estrangeiro e, ao mesmo tempo, cumprir outros compromissos com os educandos, como, por exemplo, contribuir para a formação de indivíduos como parte de suas preocupações educacionais." (PCNs BRASIL, 2006, p.91)

A Letra da música "If I were a boy" da Beyoncé mostra um comportamento pronto, uma idéia já adquirida da mulher em relação ao homem, essa ideologia diz que se a mulher interpretada na canção 
fosse um homem, ela seria um ser humano melhor e que a vida do homem é muito mais fácil que a da mulher, pois a sociedade tem responde com aceitação as indelicadezas masculinas, quanto a mulher não pode agir da mesma forma. Beyoncé apresenta nessa letra traz expressões como "I'd kick it with who I wanted" , "I'd roll outta bed in the morning". A primeira expressão tem o verbo "Kick" em português significa chutar. Essa palavra pode ter uma conotação forte e literal como bater de verdade ou "descartar", não querer mais a pessoa com quem está. A segunda expressão pode ser traduzida literalmente "Preferiria rolar na cama de manhã" ou "Mataria o tempo na cama de manhã" ou outras manias comuns masculinas.

A música é um dos gêneros que mais usa e mostra o dia a dia dos nativos, os jogos de palavras, comportamentos, os apelos, os desabafos. A forma de se expressar é característica da conversação, muitas músicas americanas tais como rap tem esse aspecto. Após a leitura da música e do debate haveria uma pesquisa de campo, as formas de tradução da música através das variáveis. Levando em conta o que Marchuschi diz sobre os gêneros textuais.

"Em especial seria bom ter em mente a questão da relação oralidade e escrita
no contexto dos gêneros textuais, pois, como sabemos, os gêneros distribuem-
se pelas duas modalidades num contínuo, desde os mais informais aos mais
formais e em todos os contextos e situações da vida cotidiana."

(Gêneros textuais 1: definição e funcionalidade Marcuschi, p13)

Após essas questões os alunos se dividiriam em grupos e com ajuda da tecnologia, das redes sociais fariam uma pesquisa de campo e trariam essa releitura da música ou nova tradução para sala de aula.

"Seguramente, esses novos gêneros não são inovações absolutas, quais criações ab ovo, sem uma ancoragem em outros gêneros já existentes. $O$ fato já fora notado por Bakhtin [1997] que falava na 'transmutação' dos gêneros e na assimilação de um gênero por outro gerando novos. [...] Em certo sentido, possibilitam a redefinição de alguns aspectos centrais na observação da linguagem em uso, como por exemplo, a relação entre a oralidade e a escrita, desfazendo ainda mais as suas fronteiras. Esses gêneros que emergiram no último século no contexto das mais diversas mídias criam formas comunicativas próprias com um certo hibridismo que desafia as relações entre oralidade e escrita e inviabiliza de forma definitiva a velha visão dicotômica ainda presente em muitos manuais de ensino de língua." (Gêneros textuais 1: definição e funcionalidade Marcuschi, p2)

O trabalho seria supervisionado e seria criado um perfil numa rede social para que todos os alunos tivessem acesso às pesquisas. No caso dos pais e avós dos alunos as pesquisas se lançariam ao comportamento social, gírias e forma de se expressar das gerações passadas. Se essas gerações concordariam com a letra da música, se eles ouviriam, se eles se portariam diferente e que linguajar 
eles usariam para traduzir a música. Outra variável colocada seria a de gerações atuais, mas de outros estados que usam de linguajar diferente e podem ter comportamentos diferentes ao da música.

O questionário será entregue em inglês e explicado, em caso de dúvidas eles serão instruídos a pedir ao entrevistado que mande suas respostas por email em documento world. A entrevista seguirá com as seguintes perguntas: Você concorda com o que diz a letra? Diga o motivo. No que isso interfere no seu modo de pensar? Você acha que isso deve mudar? Como você traduziria essa música na sua visão/época/região? É comum esse tipo de comportamento no lugar onde você mora? Você acha que a mensagem passada na musica interfere no modo de pensar dequem ouve? O que você poderia ou faria para melhorar a sociedade e a visão sexista da música? Que expressões dessa música ou parecidas com elas você já usou no seu dia a dia? Você acha que esse tipo de comportamento existe no mundo inteiro?

A pesquisa seria colocada em pauta com as seguintes características: para o grupo com estrangeiros seria:

- Pessoas de diferentes nacionalidades e um nativo de Língua inglesa(um solteiro e um comprometido);

- Adolescentes de pelo menos 15 anos e adultos a partir de 30 anos(um solteiro e um comprometido);

- Um de cada sexo;

- Qualquer preferência sexual.

Ao grupo que pesquisaria a opinião local:

- Podem ser familiares acima de vinte e cinco anos (um solteiro e um comprometido);

- Adolescentes entre treze e dezessete anos (um solteiro e um comprometido);

- Idosos a partir de sessenta anos (um solteiro e um comprometido);

- Todos da mesma localidade.

- Ao grupo responsável pela entrevista com homosexuais ou adebtos do poliamor (se assim acharem).

- Casais de diferentes idades;

- Se não encontrarem o casal, a entrevista pode ser feita com apenas um deles;

- Um homosexual de qualquer sexo (um solteiro e um comprometido)

- Pesquisar pelo dicionário Aurélia;

- Não precisa ser da mesma localidade. 
Para o grupo responsável pela entrevista dos brasileiros em vários estados seguem as seguintes características:

- Adolescentes entre treze e 17 anos de ambos os sexos (um solteiro e um comprometido)

- Adultos e a partir dos 30 anos de ambos os sexos (um solteiro e um comprometido)

- A entrevista tem que ser feita com brasileiros de outros territórios, qualquer estado exceto o que o aluno vive.

Após a finalização da pesquisa os alunos irão transcrevê-la e trazer em sala de aula as variáveis conseguidas com a letra música. Essas variáveis irão conter mais pontos de vista das diversas pessoas entrevistadas, que serão discutidos em sala para ver o que mudou na opinião dos alunos após terem conversado com essas pessoas. Ainda dentro destas discussões podem ocorrer novas palavras em português em inglês, tais como gírias, expressões novas e a origem delas. De que maneira a expressão "kick it with Who I wanted" foi traduzida ou reescrita pelos entrevistados.

\section{CONCLUSÃO}

O referido trabalho foi de suma importância para ampliar a visão dos conhecimentos e dos métodos muito comuns usados nas aulas de inglês. Os resultados esperados apontam que aluno ao ter mais possibilidades de debate sobre uma música, irá gerar familiarização com a matéria, aproximação com o discurso e a cultura dos nativos de língua inglesa, A maioria das atividades com música nas salas de aula foca a letra, onde aparece um vocabulário simples, usado em conversas, com muita repetição, que justamente o que os professores procuram nos textos. A música é popular e tem vocabulário relacionado ao dia a dia das pessoas, ou seja, palavras comuns de uso cotidiano, sendo que o conhecimento desse vocabulário facilita ao aluno a compreensão de textos em seus estudos futuros. Isoladamente canções não ensinam ninguém a usar a língua, mesmo sendo fáceis de memorizar ou cantar, em outras palavras, músicas são válidas para desenvolver determinadas capacidades tais como: ampliação de vocabulário, conhecimento da pronúncia e sons, mas elas são eficientes quando trabalhadas de maneira adequada, criativa e exploradas criativamente ao criar um elo entre o prazer de ouvir, cantar, entender e ter o domínio da habilidade comunicativa. 


\section{REFERÊNCIAS BIBLIOGRÁFICAS}

MINISTÉRIO DA EDUCAÇÃO E CULTURA. Parâmetros curriculares nacionais: terceiro e quarto ciclos do ensino fundamental: língua estrangeira. Brasília: MEC/SEF, 1998. Disponível em:

$<$ http://portal.mec.gov.br/index.php?option=com_content\&view=article\&id=12657\% Aparametroscurriculares-nacionais-5o-a-8o-series\&catid=195\%3Aseb-educacao basica\&Itemid=859> Acesso em $15 / 10 / 2009$

MARCUSCHI, Luíz Antônio . Gêneros textuais 1 : definição e funcionalidade São Paulo: Editora Cortez1998

MINISTÉRIO DA EDUCAÇÃO E CULTURA ,. Parâmetros curriculares Nacionais Brasília: 2000

GONZÁLES REY, Fernando. Sujeito e Subjetividade: uma aproximação histórico cultural. São Paulo: Thomson, 2003.

MURPHEY, Tim. Resource Books for Teachers Music and Song. Oxford University Press, 2001

MINISTÉRIO DA EDUCAÇÃO E CULTURA. Parâmetros Curriculares Nacionais para o Ensino Médio Linguagens, Códigos e suas Tecnologias. Brasília: MEC/SEF, 2000 


\section{Capítulo 3}

doi $10.37423 / 210604358$

\section{ANÁLISE LINGUÍSTICA DA MORFOLÓGICA EM LIBRAS: OS TRÊS PROCESSOS DE FORMAÇÃO DOS SINAIS}




\section{INTRODUÇÃO}

Nesse momento assunto é os processos morfológicos, com ênfase em substantivos flexionais pertencentes à área da morfologia, de uma análise do Corpus de Libras da Grande Florianópolis.

A importância deste estudo sobre análise e descrição linguística de aspectos morfológicos de Libras, para contribuir em estudos avançados em torno da linguística e da ampliação de um entendimento aprofundado dos aspectos morfológicos dessa língua como uma modalidade visual-espacial.

De acordo com Pizzio (2011, p. 22), "Os estudos linguísticos sobre a Libras são recentes - as primeiras pesquisas datadas são da década de 1980, por exemplo, Felipe (1987), Ferreira-Brito (1995), dentre outras.".

São muitas as teorias, no entanto existem poucas pesquisas acerca da flexão nominal em Libras, ou seja, há algumas limitações, o estudo-teórico em busca da construção e ampliação da categoria gramatical, especialmente na área da morfologia que se baseia especificamente, no item lexical e na internalização da formação de palavras \sinais, em especial, a flexão nominal em Libras. Dessa maneira, o objetivo principal do artigo é descrever e analisar o processo morfológico em Libras, com ênfase em substantivos flexionais pertencente à área da morfologia.

\section{OS TRÊS TIPOS DE CATEGORIA DE PROCESSOS MORFOLÓGICOS: INFLEXÃO, FLEXÃO INDIRETA E FLEXÃO DIRETA}

A nova proposta tem como objetivo são apresentar e explicitar como os processos de formação dos sinais da flexão nominal em Libras se estabelecem e se dividem em três categorias: inflexão, flexão indireta e flexão direta.

Na microestrutura linguística ou de uma língua tem a constituição da morfologia trabalha com o estudo da formação de palavras. Quadros e Karnopp (2004 p. 80) afirmam que é o estudo da estrutura interna das palavras ou dos sinais, assim como das regras que determinam a formação das palavras.

Neste contexto, este estudo procura mostrar a relação entre os três tipos de processos morfológicos: inflexão, flexão indireta e flexão direta, em três diferentes categorias gramaticais, inserido na morfologia em relação à Língua Brasileira de Sinais. 
A inflexão é uma base restrita, não é um elemento flexional, na qual todos os sinais são bases formadas por um sinal simples, não havendo alteração do significado e o movimento de sinal não é alterado. Como por exemplo, sinal de COMER = sinal simples.

A flexão direta é um sistema aberto, no entanto, é um sinal raiz permanente com a mesma posição da configuração de mãos. Dessa forma, o sinal base tem significado associado ao tempo ou ação, podendo ser pessoa ou objeto, uma vez que a flexão pode sofrer alteração, principalmente no uso do sinal, por exemplo, no movimento, na repetição e com acréscimo a outro morfema.

Em uma raiz, em um sinal invariável, se houver a flexão nominal, o sinal raiz pode mover para mais uma movimentação repetida composta por meio do ponto de articulação, direção e a expressão não manual. Na combinação entre o sinal e o movimento repetido, a configuração de mãos permanece com a mesma forma de mãos, sofrendo alteração, com o movimento repetido, provocando uma mudança alternativa, como por exemplo, sinal de COMER +++ (repetido) = comendo.

A flexão indireta é um sistema aberto e diferente do que é a flexão direta e acontece com acréscimo de um morfema e o movimento de repetição. Aparentemente, os dois sinais são unidades que formam um significado. A flexão indireta necessita do acréscimo e apresentam dois significados lexicais. No processo morfológico, a flexão indireta se caracteriza com um sinal radical que se associa a outro sinal raiz, sendo dois sinais sequenciais da mesma classe gramatical como verbo + sinal advérbio ou verbo + verbo, portanto, os dois sinais lexicais são combinados.

Assim, o sinal "COMER" é uma base e com o acréscimo do sinal raiz "JÁ", ao juntarem-se os dois sinais, forma-se o significado "COMER + JÁ" ou "comeu", que é uma marca de passado, apresentando os dois sinais lexicais e sequenciais: sinal de COMER + JÁ = comeu (dois sinais lexicais e sequenciais).

\section{METODOLOGIA}

A metodologia utilizada nesta pesquisa tem como objetivo identificar, analisar, descrever e sistematizar os três tipos de processos morfológicos dos substantivos na formação de sinais: inflexão, flexão direta e flexão indireta em Libras, por meio da análise do corpus de Libras da Grande Florianópolis.

A metodologia adotada para a realização do trabalho desta pesquisa é a análise qualitativa. O método de construção desta pesquisa vai acontecer em três etapas, como descrito a seguir: 
1) Corpus Linguístico na Grande Florianópolis.

2) Transcrição e Anotação com o vídeo de $\operatorname{ELAN}^{1}$.

3) Proposta de processos morfológicos em substantivos.

O corpus desta pesquisa será disponibilizado de forma gratuita e pública, podendo ser encontrado no site chamado "Corpus Libras repositório - Grande Florianópolis"2 . O programa Eudico Language Annotator (ELAN) foi desenvolvido para análise linguística, podendo-se trabalhar com mais facilidade o acesso à tecnologia, além de oferecer dados de linguagem, anotações, observações e registros em interações comunicativas e vice-versa.

É uma ferramenta de anotação que permite que você possa criar editar, visualizar e procurar anotações através de dados de vídeo e áudio. Foi desenvolvido [...] com o objetivo de produzir uma base tecnológica para a anotação e a exploração de gravações multimídia. ELAN foi projetado especificamente para a análise de línguas, da língua de sinais e de gestos, mas pode ser usado por todos que trabalham com corpora de mídias, isto é, com dados de vídeo e/ou áudio, para finalidades de anotação, de análise e de documentação destes (Quadros e Pizzio, 2009, p. 22).

Permite ao usuário do programa de computador do ELAN, o qual é gratuito e a capacidade boa de memória, vários participantes de mídia especificamente para identificar os sinais por meio de transcrição de glosas, antes da criação de múltiplas trilhas e das anotações, visualização em vídeo (glosas, gestos, sinais, expressão não manuais e classificadores) e bem detalhada nos aspectos linguísticos para investigação entre dois distintos são análise qualitativa e quantitativa.

De acordo com Quadros, Pizzio e Rezende (2009, p. 22) “A transcrição de dados é permitida para a pesquisa de qualquer língua. Por meio da transcrição, podemos estudar todos os níveis de análise de uma língua (fonológico morfológico e sintático)".

A pesquisa disponibiliza a utilização do ELAN usado no programa de computador para contribuir com mais facilidade com a coleta de dados para a pesquisa e analisa com a identificação dos sinais.

\section{RESULTADOS E DISCUSSÕES DOS RESULTADOS}

\subsection{DESCRIÇÃO DOS DADOS: OS TRÊS TIPOS DE PROCESSOS MORFOLÓGICOS DE FORMAÇÃO DE SINAIS; INFLEXÃO, FLEXÃO INDIRETA E FLEXÃO DIRETA}

A intenção de descrever as três categorias para analisar essa possibilidade descritiva conduz ao enfoque da formação dos sinais. 
Johnston e Schembri (2007) citam como modificação de sinais, implica que a flexão, os sinais substantivos é a modificação para expressar diferentes os significados, um sinal pode transformar em outro significado.

D`avila (2006), afirma que a flexão pode alterar a forma dos substantivos, só que de modo voluntário depende como você escolhe se quer variá-la ou não, mas dependendo do contexto e das combinações. E podemos refletir um pouco sobre a relação entre; inflexão, flexão indireta e flexão direita, em três diferentes categorias gramaticais, inserido na morfologia com a relação em Libras.

Apresenta os aspectos três tipos de categoria, entre inflexão, flexão indireta e flexão direta, como diferentes conceitos. Vejam são os três tipos de processos de formação de sinais:

Figura 01 - Três tipos de processos de morfológicos

Processos morfológicos

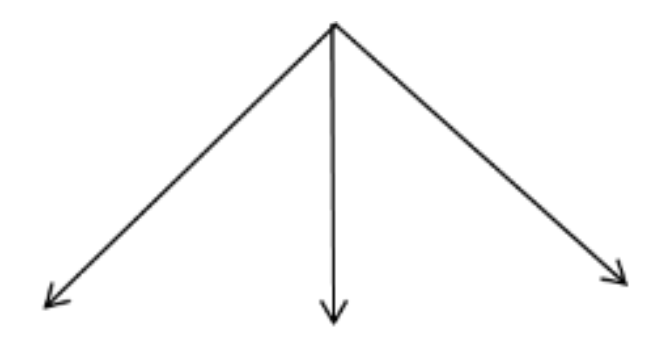

\section{Inflexão Flexão indireta Flexão direta}

Fonte: Fabricio, 2018, p. 115.

O objetivo é de mostrar a razão pela qual apontamos três aspectos dos substantivos que são: inflexão, flexão indireta e a flexão direta, conjuntos dentro da morfologia na área da flexão. Na análise morfológica, a inflexão demonstra a classificação para os nomes, incluídos na lista selecionados para cada os nomes inflexionais e ilustrados nos sinais. Observarmos os nomes na lista de inflexão, apresentada no abaixo: 
Quadro 1 - Inflexão

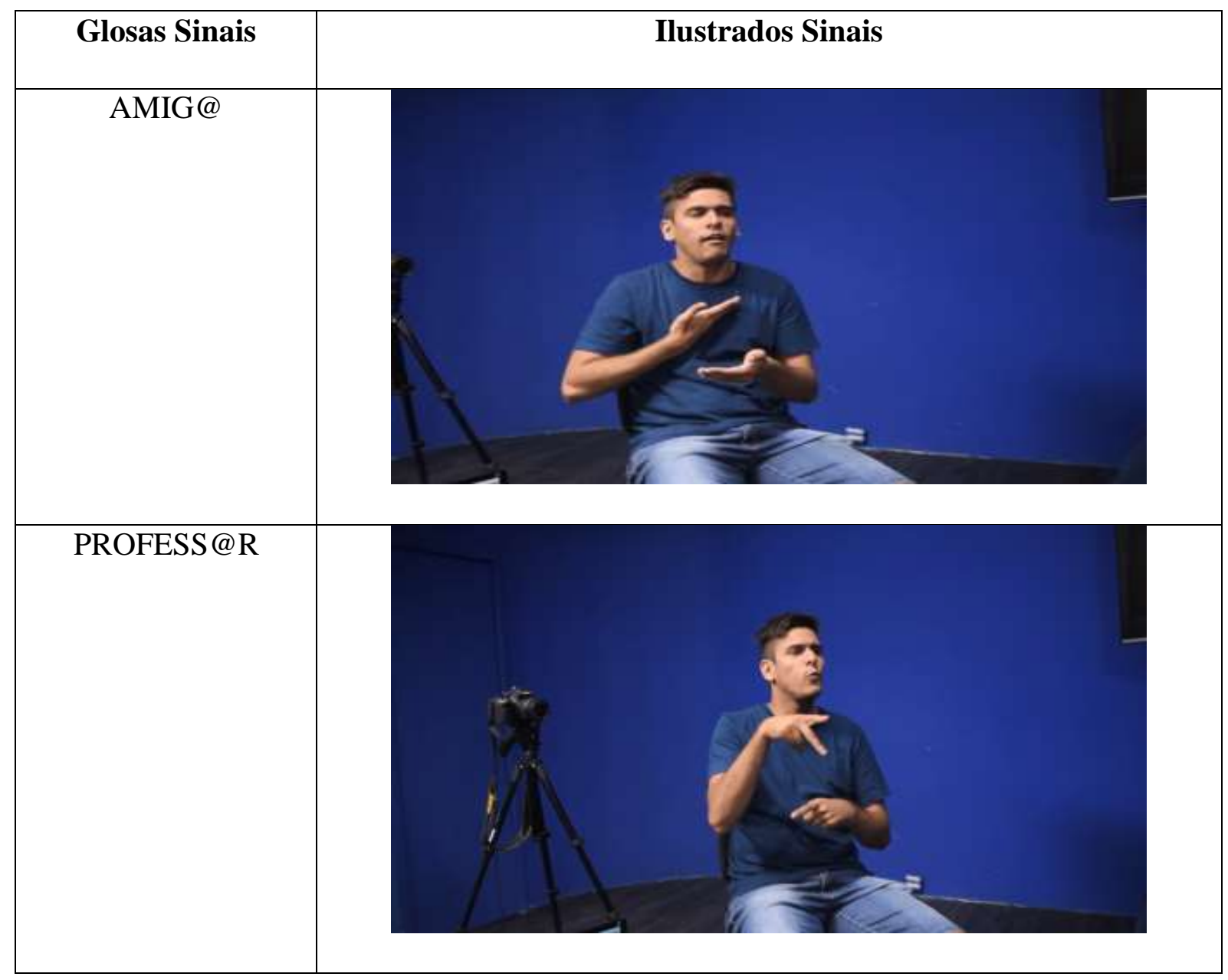

Fonte: Fabricio (2018, p. 159 a 161)

A flexão direta, especialmente nos substantivos, sofrerá a mesma flexão, o morfema gramatical, sem necessitar de outro sinal, sofre alteração de um sinal raiz permanente com a mesma a configuração de mãos, associado ao plural e pode ser pessoa ou objeto, principalmente no uso do sinal, a partir do movimento de repetição e sem acréscimo. 
Quadro 2: Flexão Direta

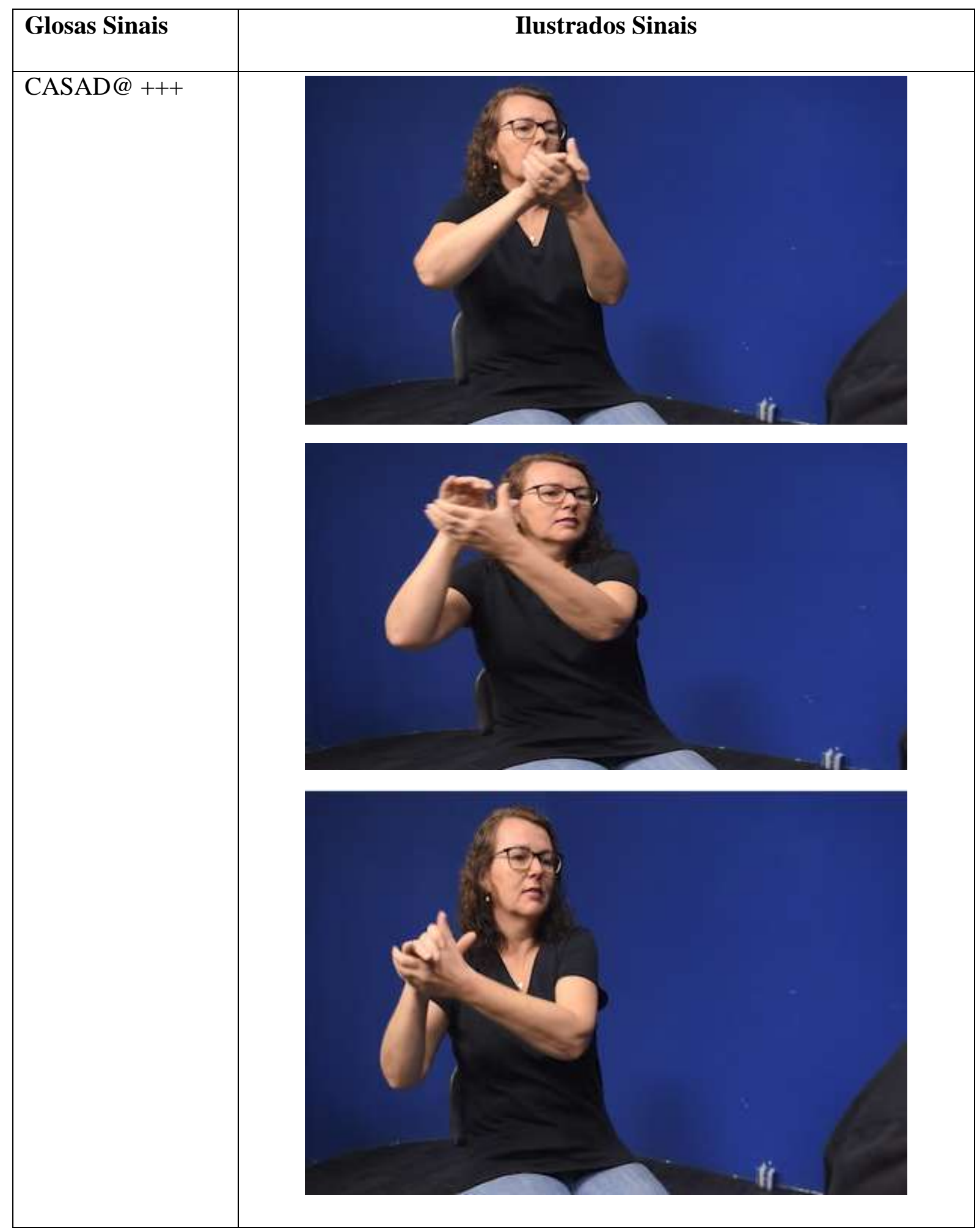

Fonte: Fabricio (2018, p. 167 a 178)

A flexão indireta é um processo morfológico de alteração e necessita do uso de acréscimo, pois o radical pode ser combinado, só que vale lembrar que a vogal temática não está entre encaixada em 
Libras, os são sinais substantivos relacionados à pluralidade, que é um conjunto dentro de uma língua, o qual sofre alteração.

Quadro 3: Flexão indireta

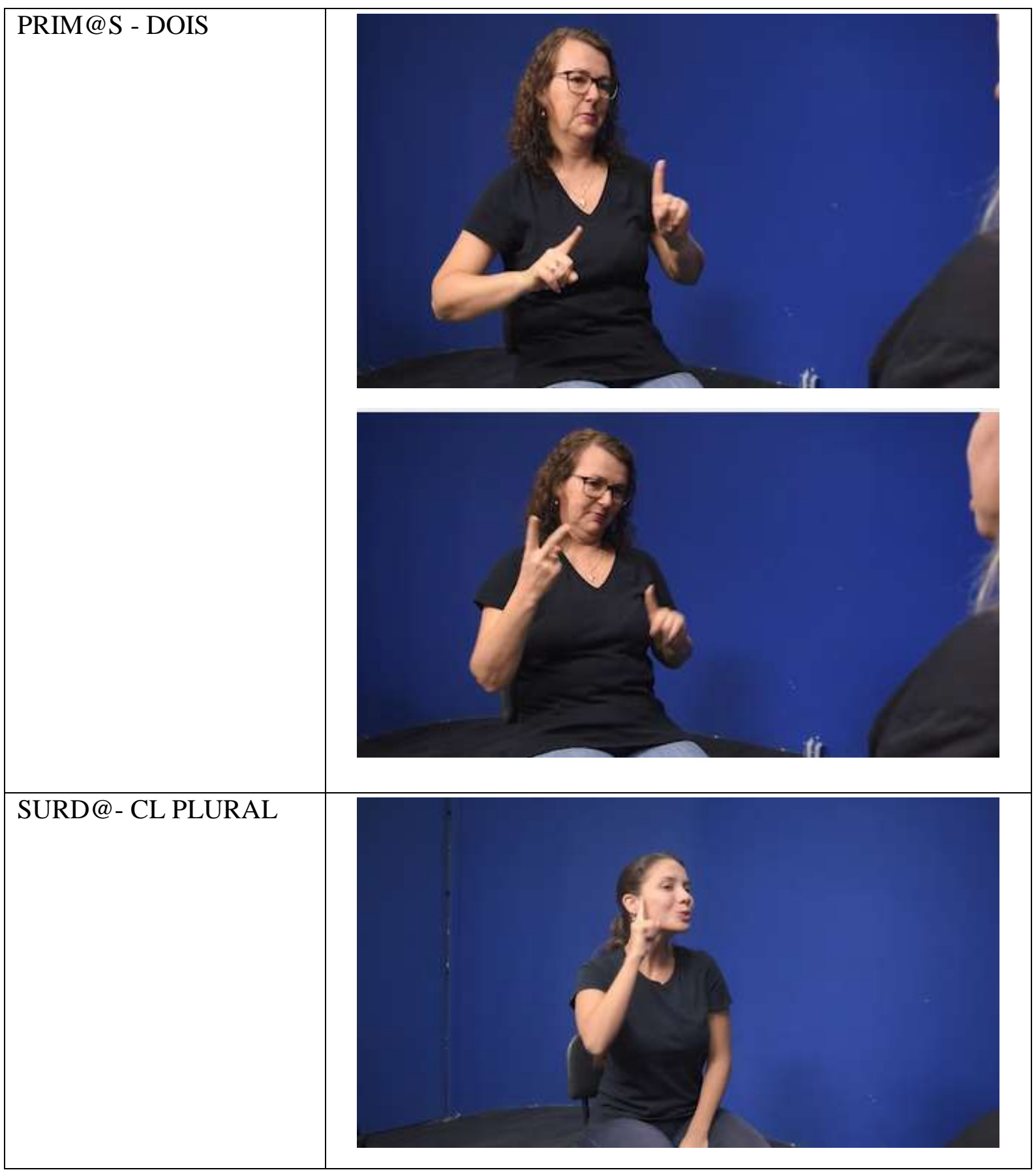




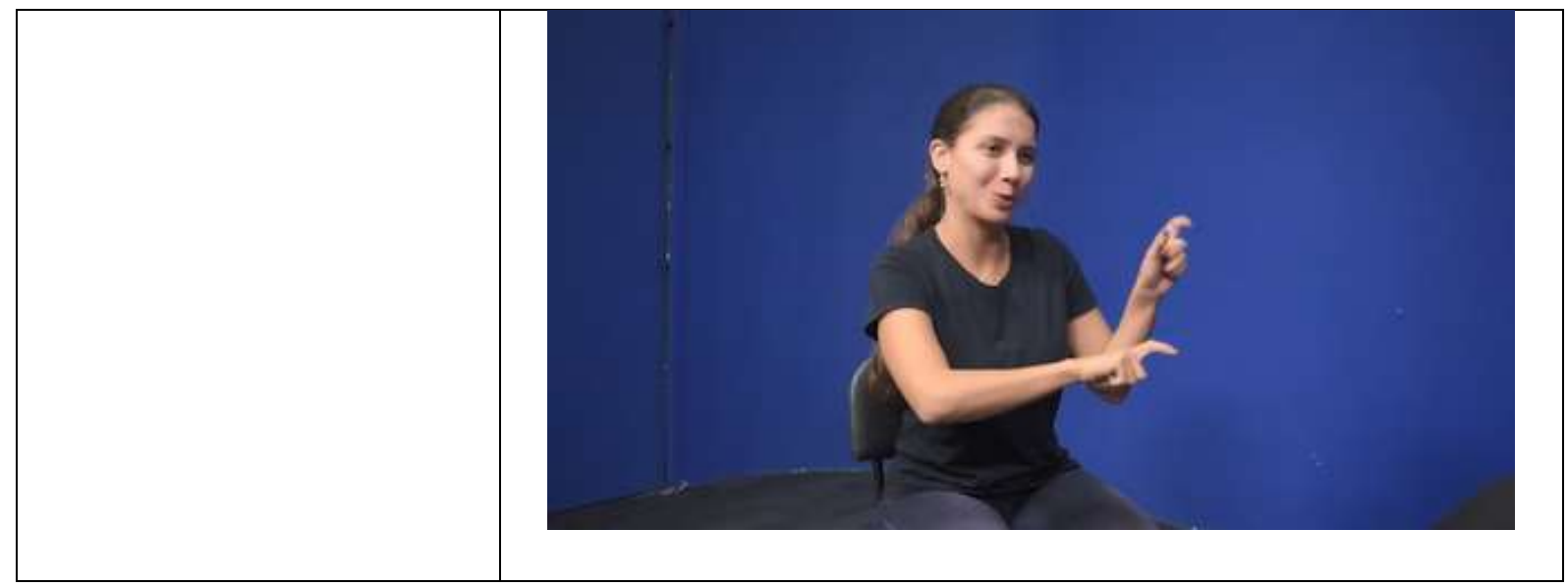

Fonte: Fabricio (2018, p. 195 a 196)

\section{CONSIDERAÇÃO FINAIS}

Os estudos de morfológicos é uma parte da gramática que tem sua contribuição com a Libras na forma mais avançada da pesquisa para construir uma nova proposta de estudo com ênfase na formação do substantivo, são como: inflexão, flexão direta e flexão indireta em Libras, por meio da análise do corpus de Libras da Grande Florianópolis.

Nesta pesquisa do artigo, os pesquisadores analisam o corpus de Libras com os vídeos, informantes diferentes por faixas etárias, gêneros, escolaridades e os níveis diferentes linguísticos. Para identificar os sinais para flexão nominal em Libras, onde estão os problemas apontados dentro do contexto e para que serve o método, primeiro coletamos os dados para observação, análise descritiva e interpretar, para apresentar os resultados explícito a categoria de flexão nominal com pluralidade.

Consideramos finais são os resultados dos dados podem ser verificados os quadros 1,2 e 3, escolhemos e analisamos, para identificar os processos dos sinais em vídeos, tem três distintos, são como: inflexão, flexão direta (plural) e flexão indireta (plural), apareceram os números de quantidade de registro dos sinais de cada grupo de processos morfológicos em Libras. Veja abaixo no quadro:

Quadro 4

\begin{tabular}{|c|c|l|}
\hline Categoria & Glosas sinais & \multicolumn{1}{c|}{ Descrição } \\
\hline \multirow{2}{*}{ Inflexão } & PROFESS@R & $\begin{array}{l}\text { A inflexão é uma base restrita, não é um elemento } \\
\text { flexional, todos os sinais são bases formadas por um } \\
\text { sinal simples. }\end{array}$ \\
\hline & CAMIG@ & $\begin{array}{l}\text { A flexão direta (plural) é uma flexão gramatical de } \\
\text { número dos sinais que se refere a mais de uma coisa, }\end{array}$ \\
\hline
\end{tabular}




\begin{tabular}{|l|l|l|}
\hline \multirow{3}{*}{ Flexão Direita } & $\begin{array}{l}\text { principalmente é associado ao movimento de } \\
\text { repetição e ao vários direcionais, não muda a forma } \\
\text { de configuração de mãos, os sinais já apareceram as } \\
\text { características dos sinais. }\end{array}$ \\
\hline \multirow{5}{*}{ Flexão Indireta } & $\begin{array}{c}\text { PRIM@S - DOIS } \\
\text { SURD@ - CL } \\
\text { PLURAL }\end{array}$ & $\begin{array}{l}\text { A flexão indireta (plural) também é marcada ao se } \\
\text { representar duas ou mais, utilizado dois sinais } \\
\text { lexicais e sequenciais, assim também é associado o } \\
\text { acréscimo de um sinal é movimento de repetição e } \\
\text { vários direcionais, a configuração de mãos pode } \\
\text { alterar outra forma de mão. }\end{array}$ \\
\hline
\end{tabular}




\section{REFERÊNCIAS BIBLIOGRÁFICAS}

D’AVILA, S. Gramática em prática: textos e exercícios. São Paulo: Editora do Brasil, 2006.

FABRICIO, R. M. Flexão nominal na Libras: análise do corpus da grande Florianópolis. Dissertação de mestrado em Linguística. UFSC. Florianópolis, 2018.

MELO, A. V. Children of Deaf Adults: CODAS em Sergipe. Interfaces Científicas - Educação, Aracaju, v. 3, no 3, p. 85-91, jun. 2015.

JOHNSTON, T. AND SCHEMBRI, A. Australian Sign Language (Auslan): an introduction to sign language linguistics. Cambridge University Press, Cambridge, UK. ISBN 9780521540568ER. (2007).

QUADROS, R. M. de; PIZZIO, A. L.; REZENDE, P. L. F. Língua Brasileira de Sinais I. Material didático do curso de Letras LIBRAS a distância. (Revisado), Florianópolis: UFSC, 2009.

SOUSA, A. N.; QUADROS, R. M. Uma análise do fenômeno "alternância de línguas" na fala de bilíngues intermodais (Libras e português). Revista Virtual Estudos da Linguagem, v. 10, no 19, p. 329-346, 2012.

STREIECHEN, E. M.; KRAUSE-LEMKE, C. A aquisição da Libras por crianças ouvintes filhas de mãe surda num contexto multilíngue. Seminário de Pesquisa do Programa de Pós-Graduação em Educação, 12, Maringá, 2013. Anais... Maringá: UEM, 2013, p. 1-19.

VARGAS, D. Z.; MEZZOMO, C. L.; KESSLER, T. M. O desenvolvimento da percepção dos contrastes mínimos na Língua Brasileira de Sinais em um grupo de CODAs. Revista CEFAC, v. 18, no 4, p. 835-842, jul.-ago. 2016.

Link do Vídeo em Libras: https://youtu.be/DPsoJJcQxOo 


\section{Capítulo 4}

doi $10.37423 / 210604364$

LIVRO DE ARTISTA COMO AÇÃO ARTE-DESIGN EDUCATIVA NO CONTEXTO DA INCLUSÃO SOCIAL 
Resumo: Este artigo integra o processo e resultado do objeto artístico obtido na pesquisa de doutorado desenvolvida na rede estadual do ensino fundamental anos finais, no período de março a julho de 2018, com o objetivo de identificar processos artísticos das artes visuais e métodos e ferramentas do design como meios para produção de objetos artísticos com temáticas voltadas à inclusão social. O processo metodológico apoiado na autoetnografia e pesquisa-ação gerou uma ação arte-design educativa com a criação do curso-vivência aplicado na pesquisa. É objetivo deste artigo a descrição do planejamento e execução do Livro de Artista/Livro Objeto, tendo como desafio a produção coletiva e colaborativa, envolvendo a organização da Expo Arte. A avaliação dos alunos sobre o processo e sua interação com os conteúdos, foi realizada por relatos escritos, estes depoimentos registram mudanças atitudinal com relação a inclusão social e de comportamento. A análise do processo metodológico desenvolvido concluiu que a articulação entre os processos criativos da arte e os modus operandi do design possibilitam a produção de um objeto artístico enfatizando a sociabilidade dos participantes por meio das vivências do fazer artístico, resultando num processo metodológico capaz de promover uma ação arte-design educativa como um caminho pedagógico/educativo/didático. Tem-se como referência SILVEIRA (2001), REY (2009), BROWN (2010), THIOLLENT (2011) e OLIVEIRA (2019).

Palavras-Chave: Arte-design. Livro de artista/livro objeto. Inclusão social. 


\section{INTRODUÇÃO}

É notório o reconhecimento do papel da arte e design para sociedade, seja na cultura, expressão de pensamento, crenças, atendendo as necessidades de produto e serviços como também nas manifestações ideológicas. Dessa interação arte - design - sociedade surgiu o interesse da pesquisa em identificar se o fazer artístico tendo como referências os processos artísticos das artes visuais e os modus operandi do design tornar-se-iam meios perceptivos, criativos e lúdicos capazes de gerar condições para o desenvolvimento da sociabilidade do grupo, com base nos princípios, valores sociais, na ética e estética a partir de uma abordagem compartilhada, promovendo desta forma ações artedesign educativas voltadas a discussão de temas relacionados à inclusão social.

A pesquisa de campo foi desenvolvida com alunos do nono ano do Ensino Fundamental da Escola Estadual Presciliano Silva, envolvendo as três turmas do turno matutino e a turma única do vespertino. A escola está localizada na Península Itapagipana, na Cidade Baixa, Salvador (BA). Essa região guarda parte da história industrial, religiosa e do sincretismo baiano.

A produção do objeto artístico corresponde a $3^{3}$ - Fase do curso-vivência, nesta fase alinhou-se a fundamentação teórica referente a livro de artista - livro objeto e inclusão social. Relembrando alguns conceitos tem-se:

Livro de Artista [...] arte contemporânea deve ser capaz de lidar com o livro de artista em todas as suas formas, o que inclui todo o grupo de objetos ou documentos assemelhados que compartilham espaços de exibição equivalentes, mesmo que sejam conceitualmente excludentes. (SILVEIRA, 2012, p.1)

Livro Objeto [...] trata-se de um campo aberto para investigações e experimentações, várias definições não definitivas convivem e compartilham operações e modos de produção: livro de artista, livro-objeto, obra-livro, caderno de artista, livro-obra entre outras. [...] é carregada de poesia e cultura, intercalando, conectando e provocando diálogos entre artes plásticas, artes visuais, literatura e design gráfico, conjugando várias áreas do conhecimento. (DERDYK, 2013, n/p)

Inclusão Social - segundo o site Mundo Educação (2018) [...] transformou-se em um objetivo a ser perseguido por várias pessoas, em uma forma de luta. Assim, existem atualmente inúmeros movimentos sociais que reivindicam da sociedade geral e do poder público a efetuação de uma real política de contrapeso às diferenças históricas e sociais constituídas no cerne da história da civilização moderna. Existem os movimentos feministas, raciais, de grupos homossexuais, de religiões africanas, bem como, pessoas com necessidades especiais. (Grifo nosso) 
Retomados estes conceitos e o pressuposto de que a produção do livro de artista se baseia em uma prática autônoma e autoral, permitindo a exploração máxima do potencial dos materiais envolvidos, disponibilizados e escolhidos. O que aconteceria se o processo de produção do objeto artístico fosse realizado por um coletivo? Desde a definição do conteúdo, formato, tamanho e material? Seria possível alcançar uma narrativa sequenciada, com unidade?

No decorrer do artigo pretende-se atender aos questionamentos a partir do Curso-Vivência que envolve planejamento e procedimentos para a execução coletiva do objeto artístico e da organização para a exposição do Livro de Artista/Livro Objeto, sendo o evento denominado de Expo Arte. A estrutura do Plano de Curso-Vivência acompanha a lógica empregada no Processo Iterativo do Design Thinking desenvolvida em três etapas (inspiração, ideação e implementação) somado aos seus métodos/ferramentas, ajustando-os de acordo com a intencionalidade da ação, o que permite uma complementariedade entre si, possibilitando a materialidade oriunda da sensibilização, ideias criativas e conceituais - tais procedimentos podem ser testados quantas vezes sejam necessárias sem repreensão, afinal esses experimentos promovem o desenvolvimento de competências e habilidades do educando, como meios também para exercitar princípios, valores, éticas e estética previstos também nas legislações do ensino.

\section{O PROCESSO METODOLÓGICO DO CURSO-VIVÊNCIA}

A Figura 1 contempla o diagrama do Curso-Vivência a partir de uma visão sistêmica entre Arte e Design $(A-D)$, a leitura é feita por colunas. Na coluna à esquerda está a proposta temática que corresponde à inspiração, foi aplicada a ferramenta do brainstorming com o objetivo de definir uma temática de forma participativa e colaborativa. A avaliação I tem o papel de analisar, retificar ou ratificar o prosseguimento. A coluna do meio aponta os conceitos, conteúdos e recursos que envolvem os materiais, correspondentes à ideação. A avaliação II tem o papel de alinhar com a coluna anterior e ratificar as ações da atual indicando a passagem para a próxima fase. A coluna da direita corresponde à Fase III, tem-se a Produção do Objeto Artístico, com a proposta de ser realizado no coletivo da escola de forma colaborativa. A avaliação final prevê o relato do processo desenvolvido. Essa visão global da proposta metodológica permite ser desenvolvida, independente da carga horária e natureza ${ }^{1}$ do curso. 
Figura 1 - Diagrama do Curso-Vivência, definição dos conteúdos, percurso e processo

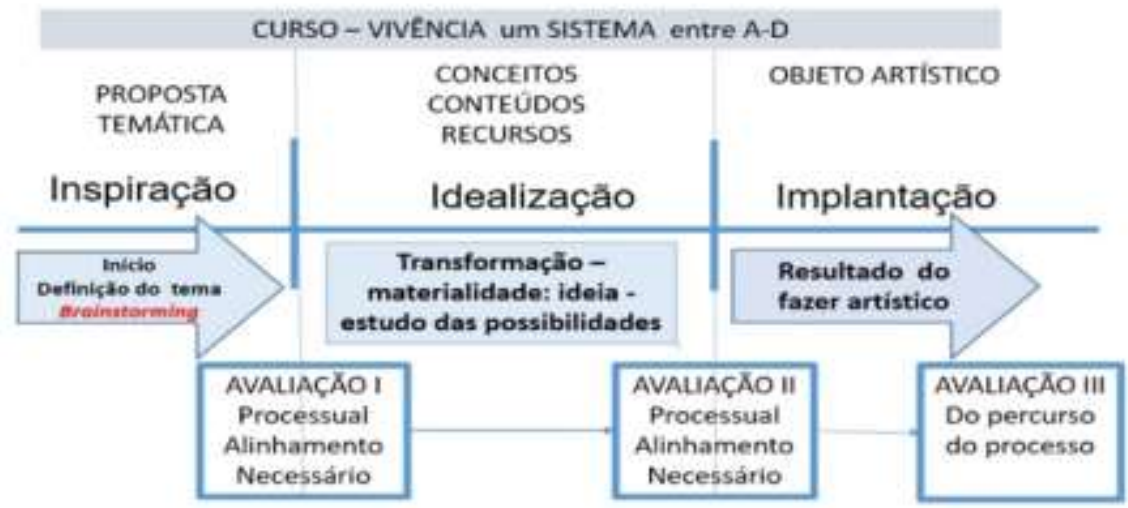

Fonte: Produção da autora (2019).

Analisando o processo iterativo do Design Thinking conclui-se que essa experiência gera confiança para planejar, selecionar conteúdos e detalhar as atividades inseridas no Programa do Curso-Vivência, entendendo que essa aplicabilidade pode auxiliar projetos de outras finalidades, como afirma Pinheiro 2010) "[...] o Design Thinking, ou pensamento de Design, é uma abstração do modelo mental utilizados há anos pelos designers para dar vida as ideias". (PINHEIRO, 2010, n/p)

Passe-se, então, ao detalhamento da Fase III que relata o planejamento da produção do objeto artístico definido como Livro de artista - Pedra Movente para Inclusão Social e a organização para a respectiva exposição. Ainda nessa etapa alguns conceitos foram retomados e outros inseridos no desenvolvimento e vivência do fazer artístico, bem como, a constatação de ações colaborativas nas produções artísticas por meio de uma solução coletiva e de cooperação.

Abraçou-se a metodologia pesquisa-ação defendida por Thiollent (2011) para reforçar o caráter social e educacional, pois a pesquisa-ação:

[...] além da participação, supõe uma forma de ação planejada de caráter social, educacional. Trata-se de facilitar a busca de soluções aos problemas reais para os quais os procedimentos convencionais têm pouco contribuído. (THIOLLENT, 2011, p. 13-14)

Neste sentido, ter-se ancorado na metodologia da pesquisa-ação permitiu que os participantes tivessem voz desde o planejamento, dialogando sobre as ações necessárias para a produção do objeto artístico. A compreensão por parte dos alunos, de que eles formam um coletivo, pois possuem interesse comum, no caso a produção do livro de artista/livro objeto denotou a importância de o processo ser colaborativo. Logo, a cooperação foi fundamental em nome do bem maior, uma vez que cada página dependia da produção da outra para que o livro, de fato, existisse. 
A produção do livro de artista/livro (objeto atendeu as seguintes características: tamanho $60 \mathrm{~cm}$ de largura por $90 \mathrm{~cm}$ de altura, material MDF de $3 \mathrm{~mm}$ de espessura, pois a ideia era que ficasse em pé e as pessoas pudessem circular em volta dele. As capas frente - fundo e as demais folhas foram alceadas por argolas de metal articuladas. Alguns alunos se surpreenderam com o tamanho, dizendo que não imaginavam que fosse tão grande, mesmo tendo visto os esboços e sabendo das medidas.

A apresentação da lista com as principais atividades foi detalhada e discutida, bem como foi apresentado o planejamento do espaço através das plantas baixa e em perspectiva a fim de nortear os passos para conclusão do curso-vivência, possibilitando ao estudante escolher individualmente em qual atividade gostaria de colaborar: pintura das embalagens; foto, filmagem e som; produção das páginas do livro ou organização da exposição. Isso requereu uma percepção de si, ou seja, das competências adquiridas e o prazer na realização da atividade, levando ao exercício da autogestão e cooperação para a produção do Livro de Artista coletivo.

A sala foi organizada de modo que os quatro grupos responsáveis pela produção das páginas trabalhassem no mesmo espaço e pudessem interagir no trabalho do colega, inclusive cooperando com as atividades. Neste movimento, entre a representação e a construção de uma narrativa, os alunos intuitivamente operaram na fronteira borrada da arte e design. Criaram as mensagens para cada tema, com propriedade, pois esta ação envolveu pesquisa tanto de conteúdo quanto de forma.

O Percurso e processo do grupo 9ำAM - Tecnologia para inclusão social (ATIS), esse grupo questionou a tecnologia na vida de Stephen Hawking (1942-2018), pesquisaram na internet, falaram dos filmes da vida dele, contextualizando a importância da tecnologia na vida de qualquer pessoa. $E$, as exigências de conhecimentos para operar sistemas informacionais. Para fazer o contraponto da temática, inspirados na escultura o Pensador (1880-1917) de Rodin (1840-1917) fizeram outras poses para criar o homem pensador do século XXI, representados na Figura 2. A pose escolhida foi a segunda pelo fato do modelo estar olhando para frente - uma aluna disse: passa a ideia de acreditar no futuro, que há esperança. Outra aluna trouxe a narrativa que a representação do novo pensador deveria ser blocada (no sentido de se criar um campo bloqueador) para que as informações fossem filtradas em prol da sanidade física e mental do humano, protegendo-o dos próprios avanços tecnológicos. 
Figura 2- Estudo mimético para criação do homem versus a tecnologia

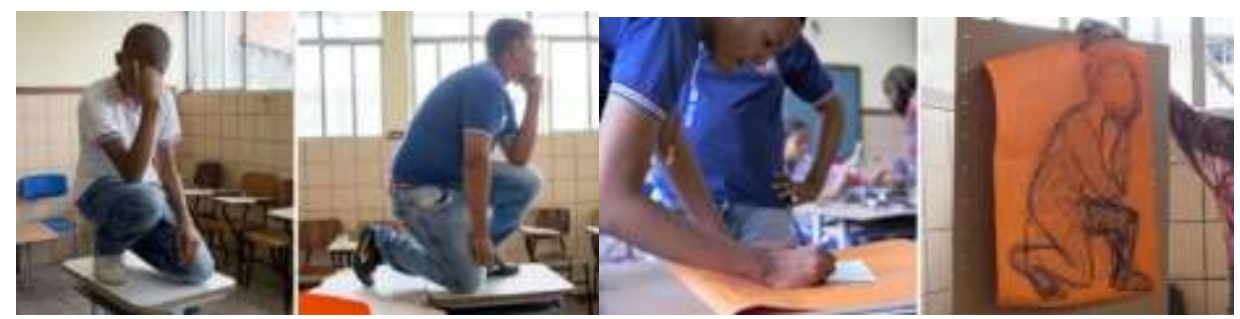

Fonte: Acervo da autora (2018).

No decorrer do processo essa narrativa foi se ampliando e se completando. Outro estudante expressou que deveria blocar o humano para que a tecnologia não tome conta do coração. Então, colocaram o coração humano fora do corpo e envolto em um coração afetuoso. Dialogando com o objeto artístico, fizeram o campo protetor para blocar o humano pintando-o de preto e cinza, conforme a está na Figura 3.

Figura 3 - Resultado das páginas do livro - G9AM: Apoio à tecnologia para inclusão social

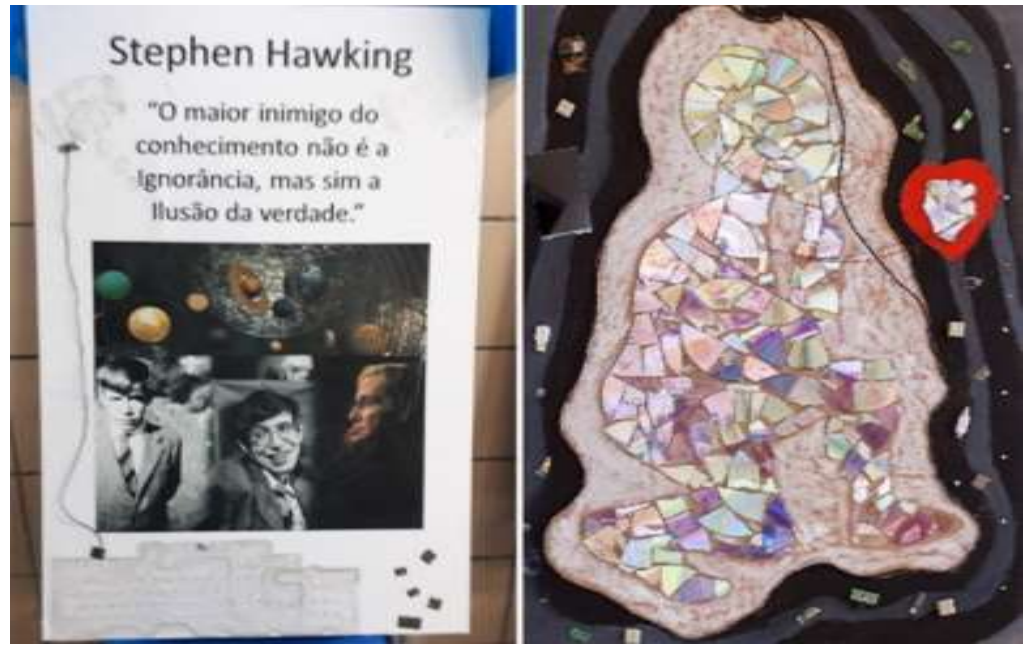

Fonte: Arquivo da autora (2018).

Para a produção das duas páginas do livro objeto com a temática ATIS foram utilizados os seguintes materiais: peças do notebook, CDs quebrados, cola quente, cola de silicone, fio, pincéis e tinta guache nas cores vermelha, preta, branca e cinza.

Queria por coisas no livro para que as pessoas quando olhasse entendessem de primeira, mas a professora falou: a arte, ela tem que falar por si só, e foi uma frase que me chamou atenção porque não só na arte, na vida da gente há coisas que queremos deixar bem explicado, mas às vezes é 
necessário a gente se calar e deixar que as pessoas interpretem da maneira delas, exemplo o nosso caráter, [...] sei que há muitos significados ainda pretendo descobrir todos eles. (Estudante - A21) ${ }^{3}$

O resultado do tema Apoio da Tecnologia para Inclusão Social (ATIS) aponta para o registro da importância da tecnologia na vida humana, a exemplo da vida de Stephen Hawking (1942 -2018), servindo como meio de comunicação e mobilidade, proporcionou mais conforto e segurança ao usuário. Todavia há uma crítica quando se aborda tecnologia, o uso de forma indevida ou excessiva traz impactos na vida humana, causando doenças, sendo imprescindível a conscientização com essa interatividade. O humano precisa aprender o momento de se blocar, fechar-se para não ser dominado involuntariamente pela tecnologia.

O Percurso e processo do grupo 9ํM - Acessibilidade com empatia, o grupo tomou como inspiração as dificuldades de as pessoas cegas andarem pelas calçadas irregulares, esburacadas, sujas, sem sinalização tátil, sem contar com a presença de lixo. Essa situação foi observada no percurso casa escola - casa. A referência para implementação da ideia, foi a imagem formada pela falta de piso em frente à sala de aula da turma. Fizeram desenhos ilustrando essa situação, pintando com tinta vermelha o piso e com tinta cinza a ausência do revestimento. Tinham a ideia de mostrar uma pessoa recebendo ajuda para fazer a travessia de uma rua com calçamento irregular. Fotografaram um aluno carregando a colega com vendas nos olhos - o aluno carregou a colega - dizendo que ela estava com muito medo.

A Figura 4 apresenta dois registros fotográficos do processo de produção - a esquerda tem-se o grupo responsável pela pintura dos buracos na calçada, uma aluna demonstra alta interatividade com a atividade de pintura que fez da palma de sua mão uma paleta. A direita outros alunos fizeram o desenho de como desejam que fossem as vias públicas, praças e jardins, principalmente os passeios de casas residenciais ou comerciais pois há moradores e comerciários que constroem de acordo com suas necessidades, acessos com degraus ou rampas, extremamente irregular.

Figura 4 - Produção coletiva e colaborativa das páginas que representam os buracos nas calçadas e a desejo de ter calçadas mais acessíveis 


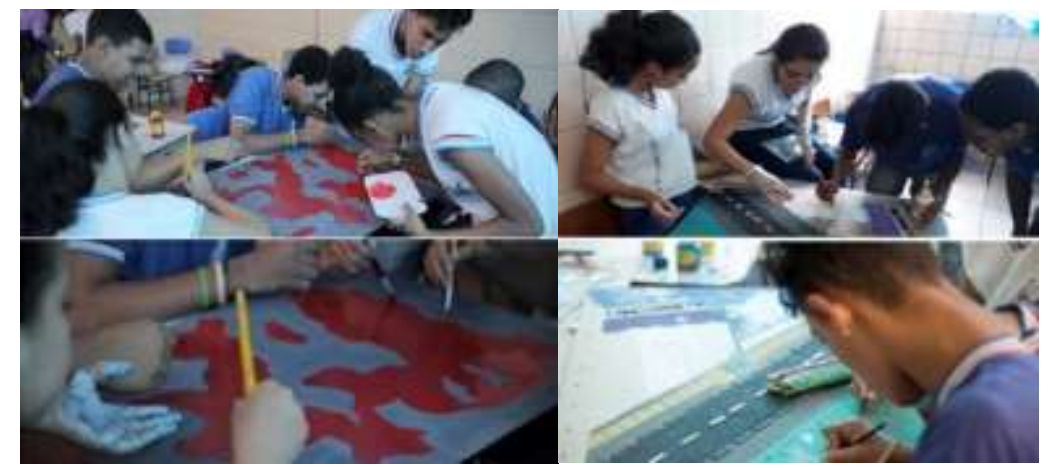

Fonte: Arquivo da autora (2018).

O resultado do "Objeto Artístico Acessibilidade com Empatia" exemplificou a reflexão sobre empatia e ao se projetar no lugar do outro, ter prontidão para servir e proporcionar melhores condições que garantam uma vida urbana com qualidade. O produto final está apresentado nos registros fotográficos da Figura 5.

Para a produção das duas páginas, foram utilizados os seguintes materiais: tinta guache nas cores vermelha, verde, preta, amarela, branca (e com as misturas foram obtidas outras cores e tons). Houve também o emprego de lixas grossas, E.V.A. e palitos de picolé.

Figura 5 - Resultado das páginas do livro - 9BM: Acessibilidade com empatia
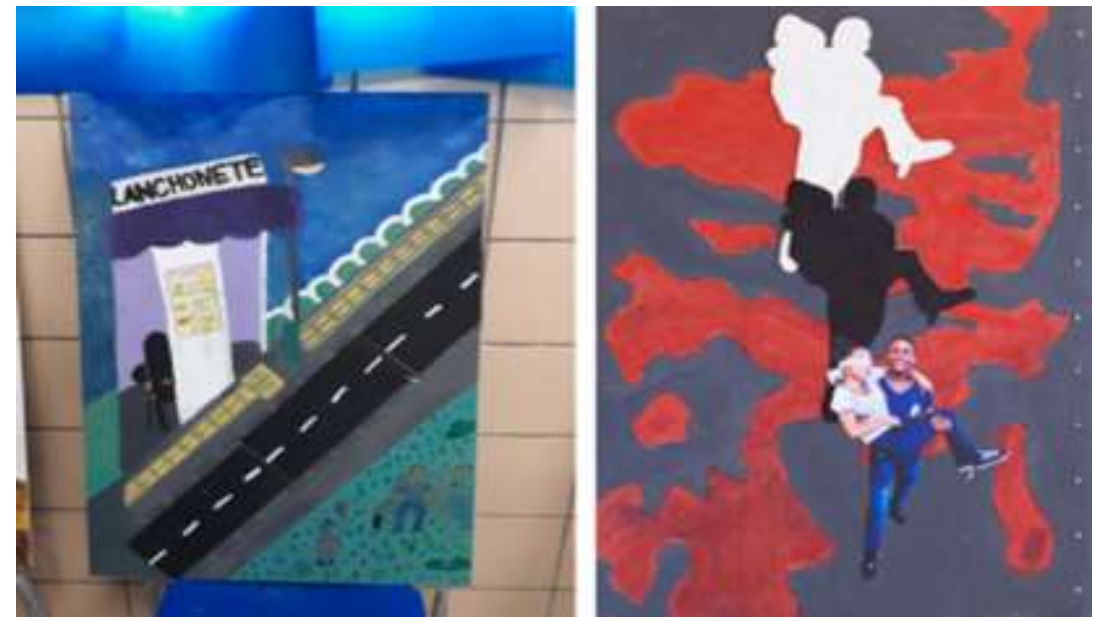

Fonte: Arquivo da autora (2018).

Quanto a expressão plástica, nota-se o emprego da perspectiva aérea referente a praça e a pista. E a perspectiva cônica com um ponto de fuga para a fachada da lanchonete, mas não para o letreiro. A composição com a escala de cores empregada dá a sensação de serenidade, com a predominância da cor verde, a representação dessa cena noturna passa a ideia de segurança, demonstrando o mundo em que se deseja viver. 
A página seguinte apresenta uma harmonia com cores que poderia ser mais vibrante, mas não o é devido ao contraste colocado entre o vermelho e o cinza - o uso da técnica da sombra dá uma profundidade à imagem dos alunos. O fato do aluno carregar uma pessoa com problemas de visão é demonstrado com a alegria de poder servir. Enquanto para a aluna que é ajudada apresenta um semblante de constrangimento e, ao mesmo, tempo interrogativo. Por que as ruas não são devidamente cuidadas?

Aprendemos possibilidades e prioridades de pessoas que possuem problemas em se locomover em lugares. O significado para mim foi mostrar que precisamos de melhoras nas ruas, calçadas e etc. (Estudante A- 6)

Foi muito importante o tema trabalhado sobre a deficiência, para termos a noção das dificuldades que os deficientes passam no dia-a-dia nas ruas. É importante lembrarmos que poderia ser a gente ali, e isso temos que levar para a vida. (Estudante - A3)

O Percurso e processo do grupo 9oCM - Empoderamento da mulher e da humanidade - a inspiração surgiu de um grupo de alunas que foram enfáticas ao trazer essa questão e falarem principalmente do assédio e da violência. A temática é atual, está nas mídias e noticiários, nos filmes e novelas, bem como, nos debates de instituições e ONGs. A falta de respeito com o que a mulher gosta de usar, a liberdade de ir e vir, bem como, a desigualdade salarial, foram pontos que acaloraram a discussão que também versou sobre a aceitação da própria mulher quanto a cor da pele, o cabelo crespo e o biótipo.

Algumas provocações foram levantadas com o propósito de fazer o grupo pensar. O que vocês consideram empoderamento feminino? O que seria necessário para que de fato o empoderamento pudesse acontecer? Como vocês imaginam o mundo se a mulher alcançasse o empoderamento? Estas provocações ajudaram na reflexão crítica da situação. Aos poucos elas foram se colocando e as palavras que mais sobressaíram, em relação às perguntas, respectivamente foram: respeito, igualdade e liberdade. A partir dessas palavras, o grupo por meio de discussão definiu a representação das duas situações tomando a mulher como base para a solução do processo. Inicialmente duas alunas posaram para as fotos e por votação, a modelo que está à direita foi escolhida por apresentar uma silhueta mais definida.

Figura 6 - Produção coletiva e colaborativa das páginas empoderamento da mulher e da humanidade 

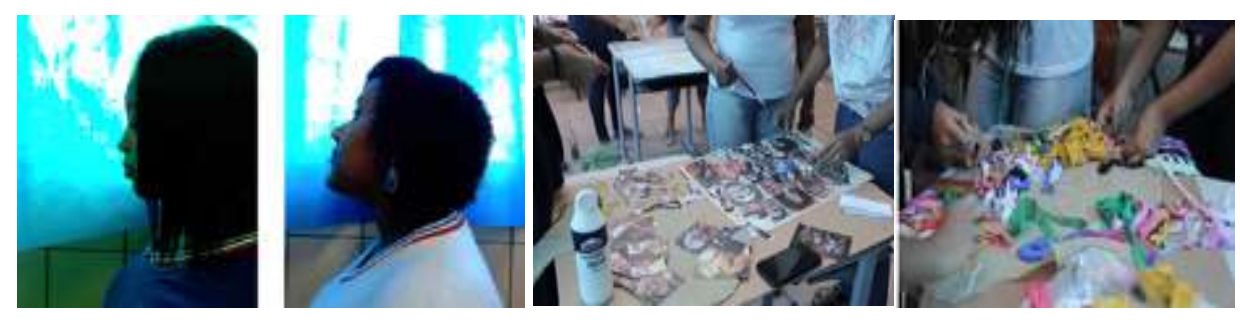

Fonte: Arquivo da autora (2018).

O empoderamento da mulher foi representado por uma cabelereira na qual algumas frases foram escritas e inseridas para reflexão demonstrando a existência de uma situação velada contra a mulher que passa pela opressão e violência. Para representar o desejo de ter um mundo realmente igual para todos colaram imagens de diversos tipos de pessoas independente de sexo, etnia, crença e religião na cabelereira da mulher, todos juntos, mostrando a diversidade humana em um único contexto, por entenderem que a forma como a mulher for tratada será reproduzida na sociedade. Daí a necessidade de ela ser respeitada e tratada com igualdade. A produção das duas páginas está representada na Figura 7. Foram utilizados os seguintes materiais: sobras de tecidos, juta crua, cortiça, bijuterias, cola, tesoura e revistas.

Figura 7 - Grupo 9o CM - Páginas do livro: Empoderamento da mulher e da humanidade

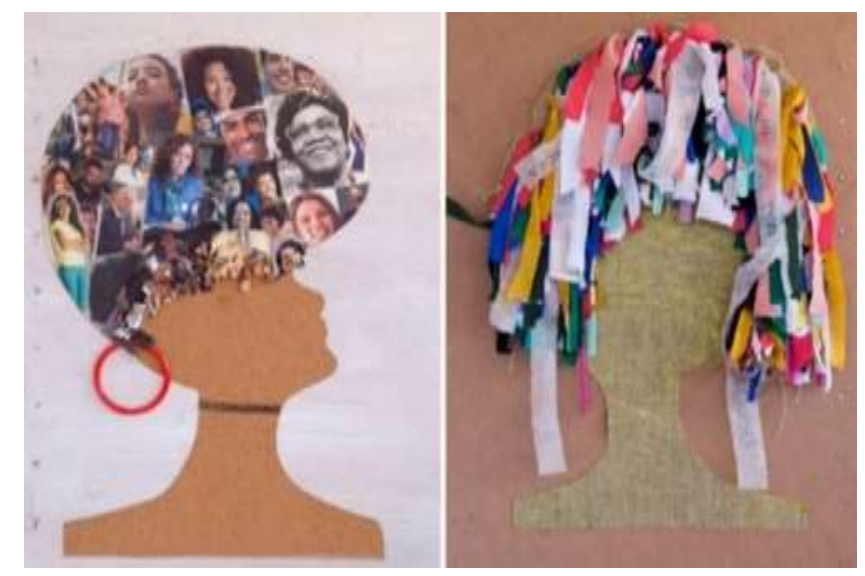

Fonte: Arquivo da autora (2018).

O que aprendi nessa exposição foi o respeito, sobre mais o empoderamento da mulher e os cadeirantes. (Estudante - A18)

Pude perceber a importância para a inclusão Social e o que me chamou mais atenção foi o tema Empoderamento da mulher e tudo com o envolvimento com amor e afeto podemos se sentir incluído e trazer experiência. (Estudante - B10). 
O Percurso e processo do grupo 9o AV - Responsa Ambiental - Este grupo se inspirou no meio ambiente que envolve a Península Itapagipana onde vivem e estudam. Por falta de consciência da população e da gestão pública ainda existem muitos esgotos que desaguam no mar. E mesmo com a última intervenção da Gestão Pública, algumas praias continuam impróprias para o banho. Sente-se a poluição nas águas do mar e nas areias das praias.

A maioria dos alunos possuem uma aproximação vivencial com este ambiente: o movimento diário da maré-cheia e da maré-vazante. A relação mar e areia funcionou como referência para o grupo construir uma narrativa e representá-la sob a ótica da responsabilidade com o meio ambiente. O grupo batizou a temática de Responsa Ambiental.

Na roda de conversa foi discutido como a natureza é bela e bondosa por proporcionar tudo que o humano precisa. Porém, há vezes em que ela também pode ser impiedosa respondendo a falta de cuidado e respeito do humano A Figura 8 apresenta dois registros fotográficos da pintura assumida pela aluna. Enquanto outros colegas foram buscar areia em uma das praias da Península para representar a poluição existente.

Figura 8 - Processo de pintura das páginas da natureza que presenteia o humano e a natureza que alerta pela falta de cuidado
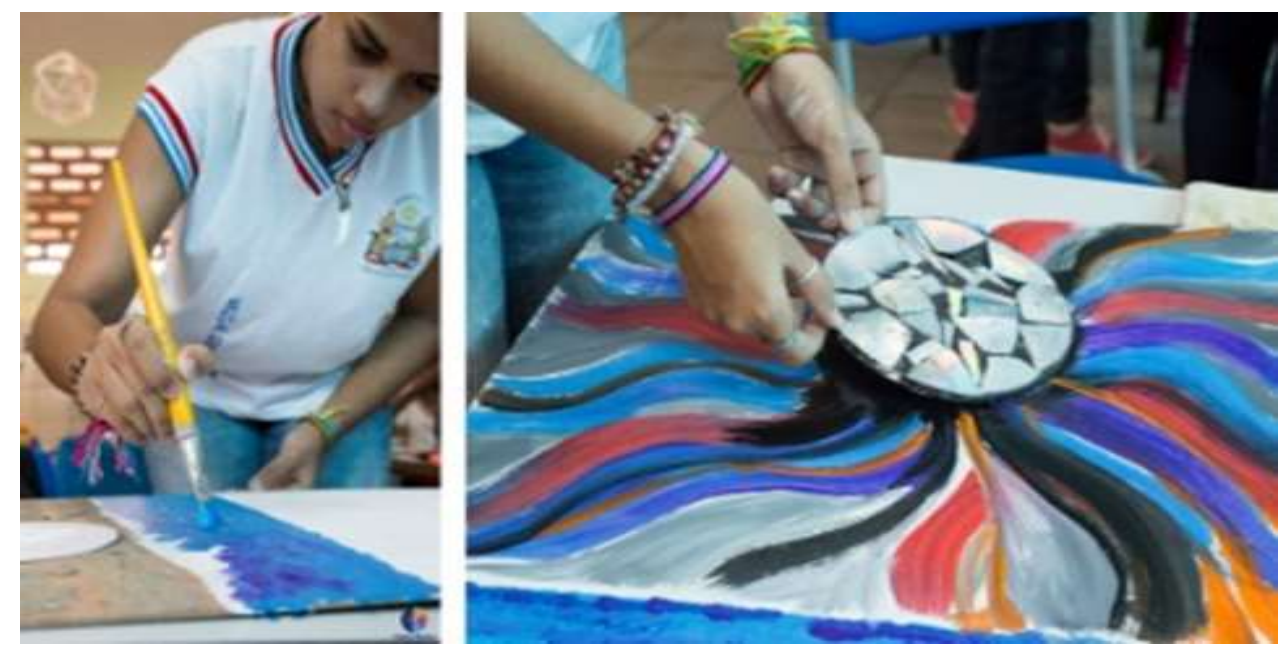

Fonte: Arquivo da autora (2018).

A narrativa foi representada pelo sol e o mar dando tudo de maravilhoso ao humano. $O$ trabalho apresenta nesta página o espelho inteiro no centro do sol, areia mais clara com flores e pérolas, mar sereno, sol refletido na água, enquanto que a outra página apresenta o espelho central quebrado, os raios do sol são vigorosos, mas não são retos, parece que estão em uma vibração intensa, como se 
fossem explodir. O resultado abraçou todas as questões envolvendo sustentabilidade do planeta a fim de garantir qualidade de vida. Os registros fotográficos da produção finalizada podem ser vistos na Figura 9.

Figura 9 - Grupo 9o AV - Páginas do livro: Responsa Ambiental
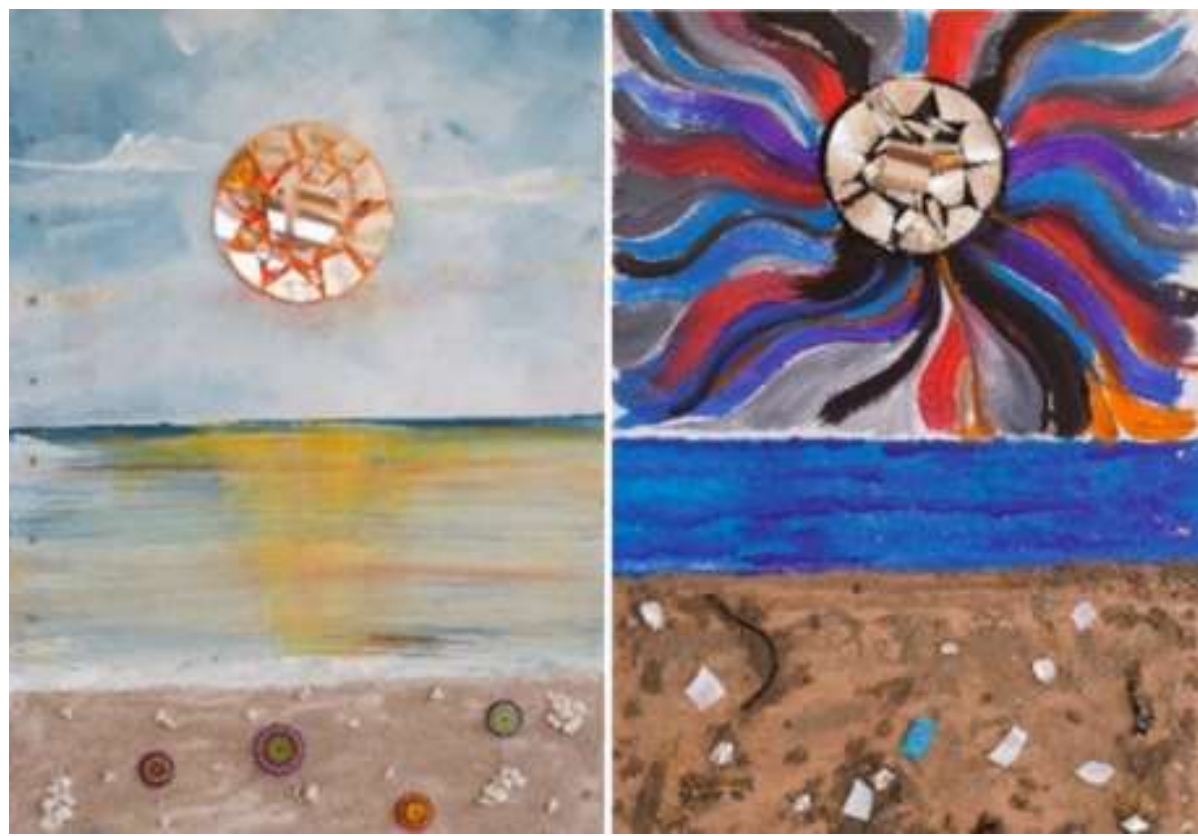

Fonte: Aquivo da autora (2018).

Foram utilizados os seguintes materiais: tintas nas cores primárias, secundárias mais as cores neutras branca e preta, areia da praia, bijuterias, cola, contas perolizadas, flores em tecido, tesoura, revistas e espelhos.

Os conhecimentos abordados na pesquisa estão presentes nas formas geométricas circulares dos CDs, dos espelhos e dos objetos inseridos bi e tridimensionais; quanto à configuração, a pregnância da forma está presente no sentido da harmonia do traçado, das cores, da ordem e do equilíbrio visual atribuído às representações resultando em ambientes distintos, como era o desejo da turma.

\section{Conclusão}

A contribuição da pesquisa foi justapor as duas situações, ou seja, abordou os princípios e valores presentes na legislação educacional por meio do Curso - Vivência, pois ambas têm o estudante como centro no processo de formação e objetivam proporcionar conhecimentos necessários para o exercício 
da cidadania pautado nos princípios, valores, ética e estética a partir do método desenvolvido no curso-vivência estruturado pelo processo iterativo do design thinking - inspiração; ideação e implementação - que interage com o processo criativo da arte demonstrando ser possível pelo fazer artístico fortalecer laços de amizade e descobrir novos amigos.

A roda de conversa sempre esteve presente nas tomadas de decisões de cada turma, antes ou depois de um fato - e assim foi no final da manhã da Expo Arte, a Figura 10 apresenta o coletivo formado pelos professores e os alunos avaliando o processo. Constatou-se que a ambiência criada durante todo o processo de produção das páginas do livro, promoveu condições para trabalhar a sensibilização e reflexão crítica sobre as questões vinculadas à inclusão social. A socialização dos resultados obtidos com a comunidade interna e externa, por meio de eventos acadêmico e sociais, favorece a prática de exercer uma ação arte-design educativa.

Figura 10 - A roda de conversa no final da Expo Art avaliando o processo

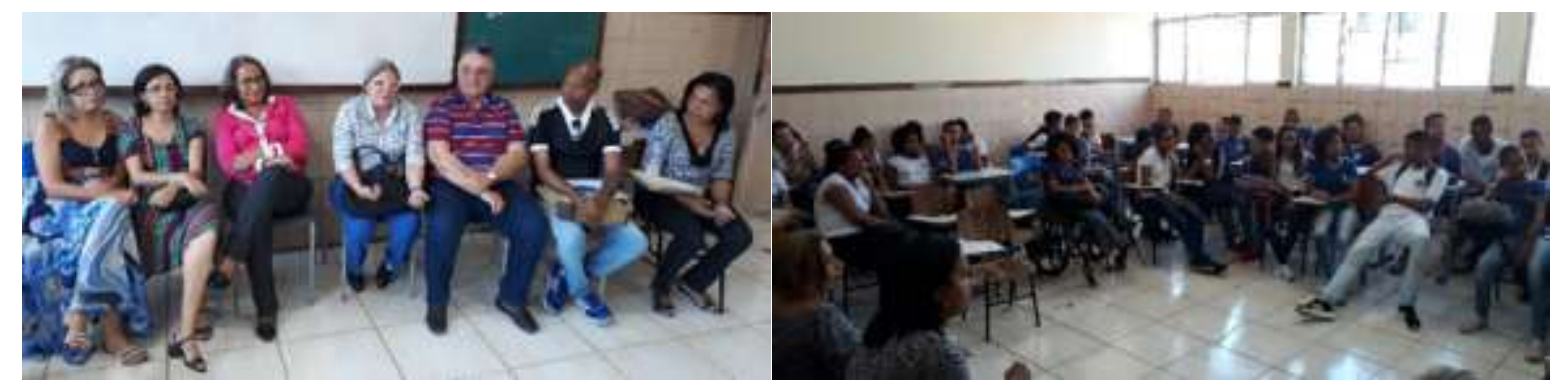

Fonte: Arquivo da autora (2018).

A aplicabilidade do processo iterativo do Design Thinking, Inclusão Social e as implementações do Fazer Artístico resultou em um percurso lógico e disruptivo, promovendo mudança de pensamento. Como o caso da(o) estudante:

Foi um trabalho que significou muito, importante foi a inclusão de pessoas, que eu nem falava para ser sincera (odiava) mas aprendi que nem tudo é como pensamos. A presença das duas professoras foi bem legal, meu maior aprendizado foi a inclusão social. Minha participação foi bem ativa ajudei em tudo que estava ao meu alcance amei muito o trabalho. Obrigada professoras! Vocês significaram muito deram esse tempo. Amo muito vocês! (Estudante-9B)

A conexão da arte e design com a área social contribuiu para ampliar a percepção dos alunos tanto de si mesmo, quanto do outro e dos serviços ao seu entorno. O depoimento do (a) estudante resume esse alcance. Tem-se a sinceridade do pensamento, demonstrando seus sentimentos, percebendo-se, reconhecendo sua contribuição para a pesquisa e compreendendo o objetivo da temática proposta (Inclusão Social). Todos os relatos dos (as) estudantes estão disponíveis no repositório das teses do 
Programa de Pós-Graduação em Artes Visuais - Escola de Belas Artes - Universidade Federal da Bahia. O filme Livro de Artista: pedra movente para a inclusão social registra o processo de produção disponível no youtube ${ }^{4}$. 


\section{REFERÊNCIAS}

BROWN, Tim. Design thinking: uma metodologia poderosa para descrever o fim de velhas ideias. Rio de Janeiro: Elsevier, 2010.

DERDYK, Edith. (Org.). Entre ser um e ser mil: o objeto livro e suas poéticas. São Paulo: Editora Senac, 2016.

FREIRE, Paulo. Pedagogia da Autonomia. São Paulo: Paz e Terra, 1999.

Mundo Educação - Inclusão Social. Disponível em: https://mundoeducacao.uol.com.br/ Acesso em: 15 mar. 2018.

OLIVEIRA, Nilda. Pedra movente: um livro de artista como ação educativa entre arte e design para inclusão social. 2019. 302f. Tese (Doutorado - Programa de Pós-Graduação em Artes Visuais) Universidade Federal da Bahia - Escola de Belas Artes, Salvador - BA.

TESSLER, Elida, BRITES, Blanca. RAY, Sandra. (Orgs.). O meio como ponto zero: metodologia da pesquisa em artes plásticas. Porto Alegre: Ed. UFRGS, 2002.

THIOLLENT, M. Metodologia da pesquisa-ação. São Paulo: Cortez, 2011. 


\section{NOTAS}

Nota 1

Natureza de curso indica se é de extensão (oficinas - aperfeiçoamento de curta duração), graduação ou pós-graduação.

Nota 2

Citado na apresentação do Livro Design Thinking de autoria de Tim Brown (2010).

Nota 3

Os relatos dos alunos mantem a redação original, estão em itálicos e codificados ao final do texto.

Nota 4

https://www.youtube.com/watch?v=WGr_Q33cs\&featu=youtu.be 


\section{Capítulo 5}

doi $10.37423 / 210604379$

\section{ANÁLISE DO PRIMEIRO MOVIMENTO DA SONATINA PARA FLAUTA E VIOLÃO DE RADAMÉS GNATALLI}


Resumo: O presente artigo tem por objetivo o estudo analítico interpretativo do primeiro movimento da Sonatina para flauta e violão de Radamés Gnattali. A base metodológica usada se concentrou na análise da partitura. Enfocou-se na análise os elementos estruturais e formais do discurso musical que forneceram subsídios para o conhecimento do estilo composicional de Gnattali.

Palavras-chave: Análise composicional, Radamés Gnattali, flauta, violão. 


\section{INTRODUÇÃO: DA ANÁLISE MUSICAL}

Fazemos a mesma pergunta que Jean Molino (1989): Analisar (música) é preciso?

É inquestionável que sim, especialmente para nós que somos filhos do cientificismo positivista, segundo a qual a ciência é considerada a única via de acesso ao conhecimento devendo o seu método ser estendido a todos os campos da indagação e da atividade humana. O sociólogo da música Max Weber (1995) chama a atenção para o processo de racionalização que passou a predominar no ocidente em todos os campos do conhecimento, inclusive na religião, notadamente a partir do século XVII. Na música, este "desencantamento" se consolida na firmação do sistema tonal. Este autor, em sua clássica obra, "Os fundamentos racionais e sociológicos da música” (1995) considera que a música ocidental passou por etapas evolutivas, partindo do irracional quando atendia a fins mágico-religiosos; ao racional quando então passa a ser um meio de expressão e gozo estético.

Entendemos este processo como um paradoxo, pois ao mesmo tempo em que a fruição se torna o objetivo da arte, o caráter de racionalidade de cálculo em que se centra a cultura ocidental prepondera também na música, traduzido pelo estabelecimento do sistema tonal, do temperamento igual e da harmonia de acordes.

O que é análise? Questiona também Molino, no texto já citado. Como ele mesmo define, "é o discurso sobre a música". Fazemos discursos sobre a música levados por diversos motivos. Vários parecem ter a nostalgia do rigor científico, "a vontade de atingir uma objetividade de análise que lhe garanta as conclusões", postura fruto da "forma mentis" assinalada no parágrafo anterior (COLI, 1990). No século XIX, a busca de um modelo de trabalho mais próximo possível do científico recebeu maior impulso, pois a preocupação predominante estava na legitimação dos saberes humanos, sociais e artísticos, através do discurso analítico. Analisar representava portanto, entender, compreender e dominar as coisas do mundo. No século XX, a busca de um discurso sobre a música baseado no modelo científico continuou a predominar, e observamos, que o analista, realiza sua tarefa tendo em vista diversos intenções.

Koellreutter (1989) considera que a análise de obra musical tem como objetivos: para os estudiosos da composição "aprofundar-se na técnica de composição do autor" e para o intérprete, que tem como missão facilitar a fruição do ouvinte, "deduzir da análise os princípios de interpretação, como o fraseado, articulação, dinâmica, andamento e outros aspectos, visando em primeiro lugar, a inteligibilidade do texto musical". 
Já nas considerações da pianista Cristina Gerling (1990) sobre a análise Schenkeriana, a eficácia da análise está em auxiliar o intérprete.

Analisar então pode significar a busca de uma consistência interpretativa no que se toca e no que se ensina, e que permite estabelecer níveis hierarquizados de intenção, contenção e ação, ou seja, no ordenamento de impulsos, direcionamento e dinâmica.

Para o ouvinte a análise musical tem também sua grande valia. A música vista como linguagem possui uma morfologia, uma sintaxe, uma fraseologia. Mesmo não sendo necessário o conhecimento desses elementos para a fruição, o domínio deles pode ampliar a esfera de compreensão estética. Como colocou Sérgio Magnani (1989): "O fruidor inteligente e culturalmente aberto sente esta necessidade". A intenção de fazer análise musical puramente objetiva e mecânica em nome de uma objetividade científica é outra tendência. Ver a música pelo prazer de uma contabilidade pode ser uma prática estéril. Como bem coloca PIENCIKOWSKI (1990) “analisar uma obra é (...) estabelecer um diálogo com ela, procurando no seu interior os elementos que nos interrogam e que nos parecem mais significativos", porém o que acontece numa análise objetiva é substituir "as notas por números" e não se respondeu a pergunta: O que é a obra?

Considerando as reflexões dos autores citados, essa proposta de análise do primeiro movimento da Sonatina de Gnattali visa, essencialmente, auxiliar o intérprete no entendimento estrutural da obra e revelar algumas possibilidades para a execução da mesma,

\section{DA SONATINA PARA FLAUTA E VIOLÃO}

Composta no Rio de Janeiro em 1959, a Sonatina para flauta e violão, além de possuir outra versão para flauta e piano, também foi transcrita pelo próprio Gnattali para flauta e cordas. Esta Sonatina é formada por três movimentos de caráter contrastante - Cantando com simplicidade, Adágio e Movido - obedecendo a um desenho formal clássico. Foi gravada pela primeira vez em Los Angeles, no ano de 1960 pelo violonista Laurindo Almeida e o flautista Martin Rutherman.

Dentre os muitos aspectos interessantes da peça o que mais salta aos olhos (ou aos ouvidos) é a capacidade única de Gnattali em unir tão simbioticamente elementos de estilos, contextualizações geográficas e históricas diversas tais como os elementos do jazz e da bossa nova no primeiro movimento, o chôro no terceiro movimento e o dramatismo e lirismo espontâneo presente no segundo movimento. 
Zanon (2006) no quarto programa da série "O Violão Brasileiro, nossos compositores - Radamés Gnattali 100 anos" na Rádio Cultura FM, faz as seguintes considerações a respeito da Sonatina para flauta e violão:

Gnattali escreveu a sua Sonatina para flauta e violão em 63 no auge da bossa nova, o que é evidente na intimidade de expressão dessa peça. (...) Cada movimento é baseado em um gênero de choro respectivamente o xote, a serenata e o chorinho. Essa adstringência harmônica dá um tom bem moderno a obra, mas o que prevalece é essa voz sussurrada, discreta da bossa nova.

Nota-se que a data de composição citada por Zanon é diferente com a que consta no "catálogo digital Radamés Gnattali”, que coloca a data como 1959, devido, provavelmente, a algum erro editorial. Além do mais, no primeiro movimento, não encontramos elementos que caracterizassem o xote descrito por Zanon.

Consta no catálogo digital existente sobre Radamés Gnattali e concebido por Roberto Gnattali (2005) ${ }^{1}$, que a Sonatina foi dedicada a Laís de Sousa Brasil e Norton Morozowicz. Não pudemos encontrar essa dedicatória nas partituras encontradas.

Desta obra pode-se encontrar as seguintes versões:

- Publicada pela Chanterelle Verlag: 32 páginas. Dimensões: 9 x 12 . Ano de 1997 com digitação na parte do violão por Laurindo Almeida.

- Uma partitura com 18 páginas a tinta, da página 1 à página 15 , copiadas pela irmã de Gnattali, Aída Gnattali. Páginas 16 e 17 copiadas por Nelly Gnattali.

- Uma partitura com 15 páginas, grande, a lápis, copiada por Radamés Gnattali, e que inclui, além da parte da flauta e do violão, a parte de piano. $42 \times 28 \mathrm{~cm}$. Essa partitura está em poder da esposa de Gnattali, Nelly Gnattali.

- Manuscrito com 26 páginas a tinta com nome da copista Esli Barbosa no canto direito da última página.

- Parte da flauta separada, com indicações em inglês sugerindo as viradas de página, sem nome da edição ou copista.

Não tivemos acesso às cópias feitas à mão por Radamés Gnattali e por Nelly Gnattali. Todas as demais partituras que tivemos em mãos traziam aquilo que demonstrou ser um erro editorial no compasso 109, constatado após verificação da presença de um padrão melódico em terças utilizado em diversos trechos anteriores. 


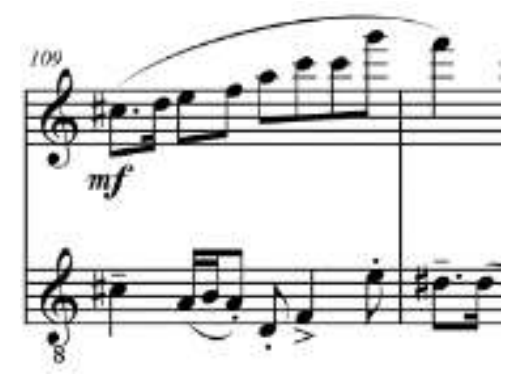

FIGURA 1 - Compasso 109 com erro editorial.

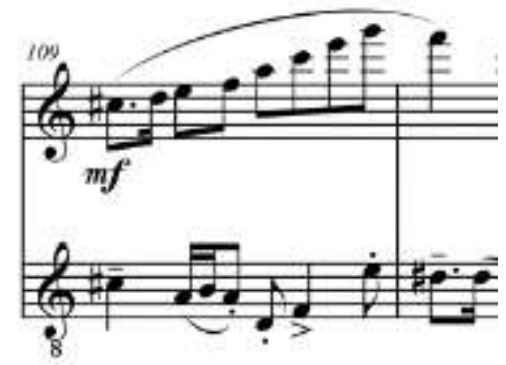

FIGURA 2 - Compasso 109 corrigido.

Na edição da Chanterelle Verlag foi encontrado outro erro na data da composição da Sonatina, em que consta como 1963 posto que o correto seja o ano de 1959 como já foi citado anteriormente.

Para esse trabalho utilizaremos a edição da Chanterelle Verlag tanto para a análise estrutural da peça quanto para a comparação dos intérpretes. Esta escolha se dá em função da legibilidade, completude e credibilidade da mesma em comparação com as demais versões obtidas, além de ter sido a mesma escolhida por pelo menos dois dos três intérpretes analisados ${ }^{2}$.

\section{ANÁLISE DO PRIMEIRO MOVIMENTO: CANTANDO COM SIMPLICIDADE}

Mendonça (2006) em sua dissertação de mestrado "A guitarra elétrica e o violão: o idiomatismo na música de concerto de Radamés Gnattali" afirma que era muito comum Gnattali utilizar formas clássicas no diminutivo, como por exemplo: sonatina, concertino, pequena suíte, não só por suas dimensões menores, mas possivelmente em respeito aos grandes mestres que admirava.

O primeiro movimento foi construído de acordo com a forma sonata. O esquema temático pode ser entendido tanto como $A B(A) B A$ quanto como $A B\left(C A^{\prime} C^{\prime} A^{\prime \prime}\right) B^{\prime} A$, em que a idéia $A$ retorna após o primeiro $B$ dentro de um processo de desenvolvimento. A título de facilitação da compreensão, será adotado um roteiro de análise baseado nessa idéia clássica de exposição, desenvolvimento e reexposição. 
Sobre a utilização da forma sonata por Gnattali e como ela influenciou sua obra, Cavalcante (2002) faz as seguintes considerações:

\begin{abstract}
"Quanto à forma sonata, é muito apreciada pelo compositor. (...) O material temático denota um apuro, um refinamento que, embora mantenha a característica principal que é o aproveitamento dos elementos provindos da música urbana, estão mais diluídos na manipulação "formal". Talvez, no caso da obra de Radamés Gnattali, a forma sonata tenha influenciado positivamente no refinamento da música considerada pro ele como "música de concerto".
\end{abstract}

O quadro abaixo descreve essas seções do primeiro movimento da Sonatina:

\begin{tabular}{|c|c|l|}
\hline Aspecto formal & Compassos & \multicolumn{1}{|c|}{ Descrição } \\
\hline \multirow{2}{*}{ Exposição } & $1-37$ & Tema A \\
\cline { 2 - 3 } & $38-72$ & Tema B \\
\hline \multirow{4}{*}{ Desenvolvimento } & $73-78$ & Variação do tema A em Lento \\
\cline { 2 - 3 } & $79-92$ & Variação ritmico melódica do tema A \\
\cline { 2 - 3 } & $93-100$ & Reaparece a idéia do lento transposta e modificada. \\
\cline { 2 - 3 } & $101-108$ & Nova variação ritmico-melódica sobre A \\
\hline Transição & $108-111$ & Elemento de ligação criado a partir do tema B \\
\hline Reexposição & $112-132$ & Tema B transposto \\
\cline { 2 - 3 } & $133-156$ & Tema A \\
\cline { 2 - 3 } & $151-156$ & Coda \\
\hline
\end{tabular}

\title{
Exposição
}

\section{A) Compassos 1-37}

Nesta primeira seção é proposto o primeiro material temático do movimento. De caráter cantabile e melodioso, predominantemente em legato, divide-se em dois períodos, separados por uma vívida e breve passagem em semicolcheias que aparentemente vai modular para Mi maior, mas nos compassos 15-16 Gnattali realiza os II-V de Sib menor e Ab menor totalmente afastados de Mi. A surpresa fica por conta dessa nova "tonalidade" inesperada e pela dinâmica em piano. Soma-se a eles uma longa frase que ao final decai e finaliza suavemente a seção A. Os acordes são mais em "bloco" com algumas poucas conduções executadas pelo baixo.

B) Compassos 38-72

A segunda seção traz bruscamente o outro material temático, cujo caráter mais rítmico oscila entre o jocoso e o grotesco. A articulação é diversificada, inclusive ocorrendo momentos de diferentes articulações simultâneas entre as vozes, por se tratar de uma seção repleta de toques contrapontísticos e imitativos. A voz do violão ganha mais independência, com função mais melódica, 
exceto nos compassos 49 onde o ritmo torna-se um fator importante, quase que percussivo apesar da progressão cromática que surge dele.

\section{Desenvolvimento}

Nesta seção, idéias da seção A são fragmentadas, transpostas, reordenadas e modificadas em seus aspectos intervalares. A seção estrutura-se da seguinte maneira: tem-se uma pequena passagem em Lento, sobre motivos modificados de A, e em seguida aparece uma variação rítmico-melódica sobre a harmonia do primeiro período de A. Reaparece a breve idéia em Lento, por sua vez também transposta e modificada, e logo entra uma nova variação rítmico-melódica, agora sobre a harmonia do segundo período de $\mathrm{A}$.

C) Compassos $73-78$

Passagem lenta, com pequenas figuras melódicas extraídas do tema $A$, além da mesma maneira de tocar os acordes: primeiro o baixo separado e em seguida as demais notas.

\section{$\left.A^{\prime}\right)$ Compassos 79-92}

Trecho musical com algo bem semelhante ao tema A (inclusive na harmonia quase igual). Uma das diferenças entre $A$ e $A^{\prime}$ é a melodia entremeada de tercinas e semicolcheias de caráter quase improvisatório.

$\left.C^{\prime}\right)$ Compassos 93-100

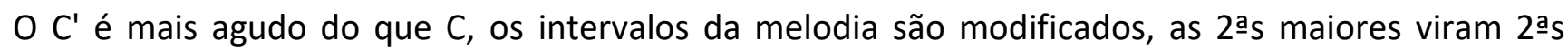
menores e etc., além dos acordes serem totalmente diferentes. É dois compassos maiores do que $C$.

$A^{\prime \prime)}$ Compassos 101-108

Além das tercinas e semicolcheias (diferentes daquelas de $A^{\prime}$ ), esse pedaço simplesmente é baseado na segunda parte de A (aquela do two-five). O violão e alguns compassos da flauta também chegam a ser idênticos ao que eram na exposição.

\section{Transição}

Compassos 108-111

Brevíssimo elemento melódico de ligação, de três compassos, criado a partir de motivos extraídos de B.

\section{Reexposição}


Essa seção é notória por seguir a ordem inversa da exposição, ou seja, reapresenta-se primeiro o parágrafo $B$, transposto e com modificações, e só então o parágrafo $A$, praticamente idêntico à 1av vez, exceto pelos 6 compassos finais. Obtém-se assim um verdadeiro efeito de retorno da primeira idéia melódica, uma sensação efetiva de reencontro com os contornos originais da mesma, sensação essa que é tão mais forte quanto já era inesperada pelo ouvinte a essa altura do movimento.

B') 112-132

A melodia do tema B desta vez aparece em outra altura, com pequenas modificações que antes não tinha (as colcheias do compasso 117), retirou aquele pedaço de imitação entre violão e flauta, o violão mudou a altura ficando bem diferente.

\section{A) $133-156$}

O fim do movimento fica por conta de mais um eco jazzístico no sentido de uma lembrança, uma semelhança, uma referência a um estilo previamente experiênciado anteriormente pelo ouvinte, na forma de uma pequena coda, ritmicamente um tanto "manhosa". Explora todos os registros da flauta e finaliza com uma descida sinuosa, típica da linguagem do jazz, concluindo na nota mi, tendo ao fundo um acorde de dó maior executado no cavalete pelo violão.

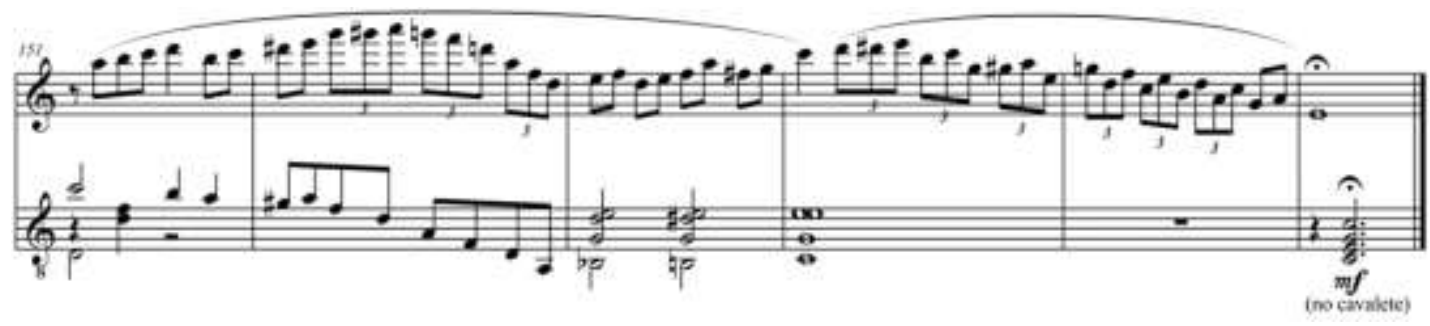

FIGURA 7 - "Eco jazzístico".

Quanto ao tratamento da harmonia por Gnattali, Cavalcante (2002) nota que:

(...) prevalece as intenções de um trabalho modal e os contrastes entre as seções, no confronto dos respectivos tratamentos temáticos; predominância de um centro tonal com uso de: inflexões nos modos maior e menor, mistura modal, algumas obstruções da tonalidade, movimento harmônico rápido, cromatismo mais diluído e um sentido improvisativo.

Em termos de harmonia, podem ser detectados no primeiro movimento inúmeros elementos de tonalismo "centrado" na nota Dó, embora a obra não soe enfaticamente como tal.

O movimento termina em Dó Maior: isso é importante. Vários pontos de apoio da melodia são notas da escala de dó, notas importantes como sol, mi, a sensível si (especialmente pontos de apoio rítmico/melódico, como notas ligeiramente mais longas que as demais ao redor, ou os pontos 
culminantes graves e agudos de uma determinada frase). Essas notas importantes vêm rodeadas de notas "estranhas", alteradas, mas sem perder o foco. E tem diversos acordes próprios do campo de Do $M$, tipo F, Am7, G7/13/9, etc. Pode-se afirmar que o primeiro tema está mais para dó; o segundo tema e as seções lentas de "desenvolvimento" são mais cromáticas ou em "tons" afastados.

Há de se assinalar que Gnatalli, com suas "intenções de um trabalho modal”, ou, diríamos, fazendo uso do modalismo livre, adota um procedimento que é marca na música erudita, conforme assinala PAZ (2002):

\begin{abstract}
"Diferentemente da música folclórica, em que os modos se mostram na maioria das vezes claros e nítidos, na simplicidade de seus tipos primários, através de melodias às vezes bem simples, na música dita erudita, de uma maneira geral, eles se apresentam muitas vezes obscurecidos por melodias construídas através de técnicas composicionais complexas e sofisticadas. As vezes, dentro de uma mesma canção, um determinado grau oscila. Outras vezes é a tônica que não se define bem e o centro de atração do modo parece ser ora uma nota da escala, ora outra.(...)os modos são tratados de forma muito livre, sendo freqüentemente alterados e modificados na sua estrutura(...) Assim as escalas modais ficam subordinadas à criatividade do compositor e ao tratamento composicional dado ao material (...).
\end{abstract}

PAZ, Ermelinda A. O modalismo na música brasileira. Brasília: Musimed, 2002.

O autor utiliza progressões harmônicas e sonoridades jazzísticas incorporando tensões próprias desse estilo no uso de acordes em terças típicos do sistema tonal (às vezes sem a terça ou a quinta, mas acrescidos de sétimas, nonas, décimas primeiras e mesmo décimas terceiras), com algumas inversões e muito freqüentemente recheados de alterações ao que poderia ser uma região tonal momentaneamente delineada.

Nos quatro primeiros compassos temos os seguintes acordes respectivamente: Dm11/9/7/omitt3 , Gm9/7, C7M, Em11/7, G13/11/9/7/omitt33 , Bb13/9/7, A13/9/7. O esquema Dm - G - C é subvertido pelo si bemol no $\mathrm{Gm}$. De Bb7 para A7 pode ser visto como um subV de uma dominante secundária que aliás não se resolve no acorde esperado - Dm ou M.

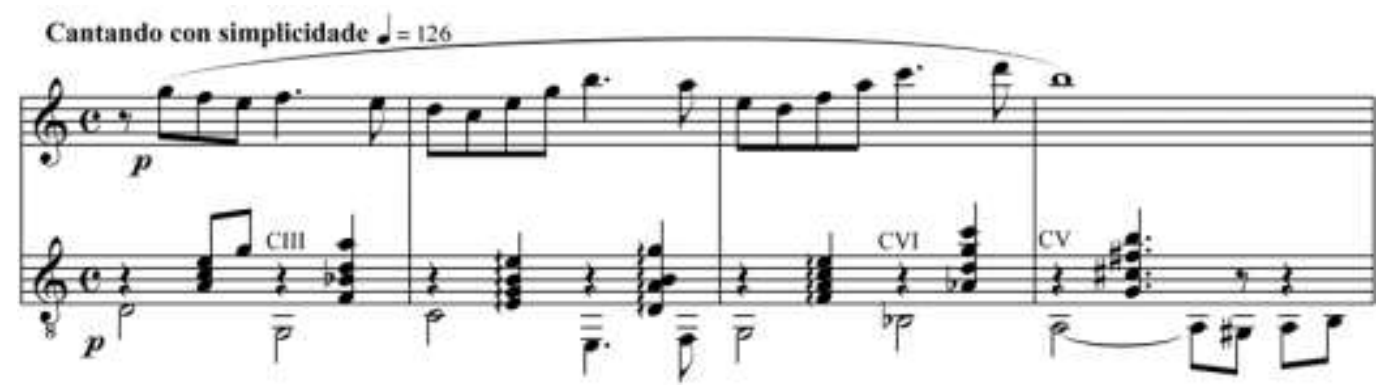


FIGURA 3 - Harmonia com acordes de sétimas, nonas, décimas primeiras,etc nos compassos 1-4.

Algumas vezes, essas possíveis regiões tonais recém sugeridas são logo em seguida bruscamente abandonadas, em direção a "tons" mais afastados. Isso, aliado tanto ao uso de acordes que guardam distância de quinta entre si, porém sem as relações intervalares internas inerentes ao binômio tônicadominante, quanto à não resolução de acordes de conformação dominante conforme esperado pelo ouvido lógico, leva à ambigüidade que oculta as características tonais da peça, especialmente ao somar-se com os contornos ora modais, ora cromáticos da melodia.

Queremos entender como "ouvido lógico" o fato de que o ouvido humano criado no Ocidente possui a tendência de procurar uma referência tonal o tempo inteiro. Procuramos a terça, a quinta justa, tanto na harmonia quanto na melodia. Gnattali sabia disso e de vez em quando cria a expectativa de uma certa tonalidade que logo descarta como, por exemplo, na primeira frase que termina no compasso 4 e veio de um Bb - A7, sugerindo a dominante de Rém. Só que Gnattali coloca um si natural e um fá\# no acorde de A7, ficando ambíguo entre Rém e M. Nos compassos 13-14, ele dá a entender que vai ficar em MiM, mas logo muda. No segundo tema, a partir do compasso 38 ele faz algo que lembra Mim, depois já parece Solm (compasso 44). Gnattali utiliza muitas "notinhas" estranhas que despistam ou deturpam esses "tons".

Distantes ecos de harmonia jazzística podem ser ouvidos em algumas progressões típicas da técnica "two-five", com condução de vozes cromática.

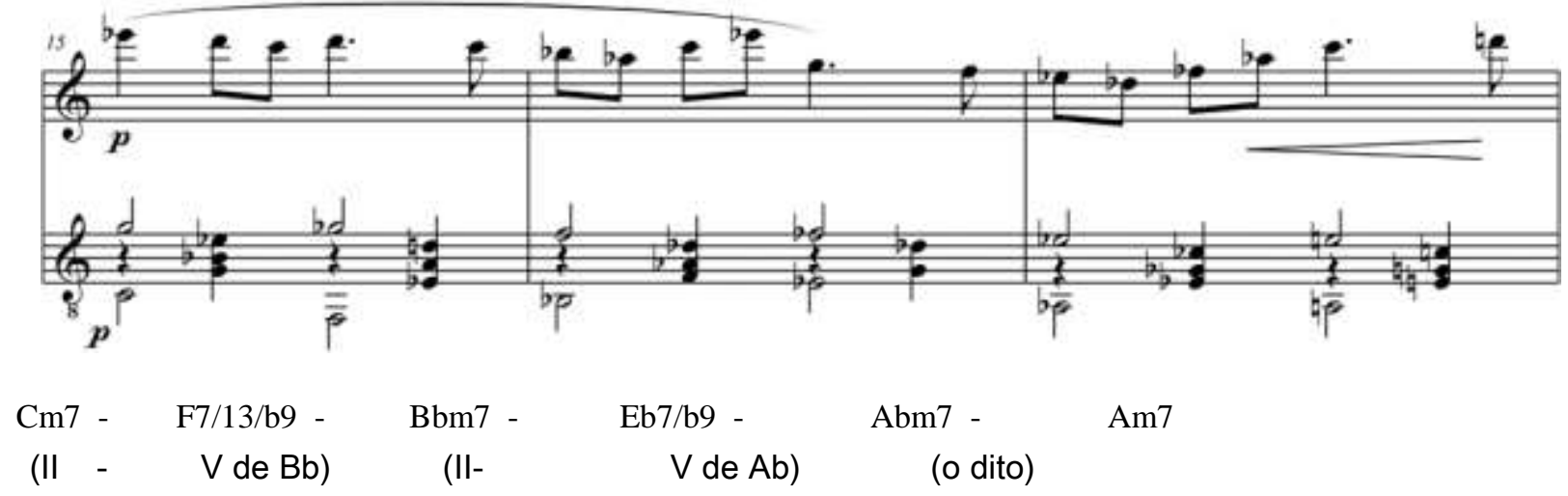

FIGURA 4 - Compassos 15 a 17 com condução de vozes cromática.

O two-five ou II - V consiste em preparar qualquer acorde pelo que seriam o II e o V graus na sua tonalidade própria (Exemplo: em DóM, prepara-se o acorde do IV grau com Gm e C7, respectivamente o II e o V graus do tom de FáM). Esses acordes II - V podem vir temperados com alterações e podem 
ser feitas longas cadeias de II - V, como um ciclo de modulações relâmpago. Observa-se isso especialmente no jazz.

A música de Radamés encontra-se nos horizontes do movimento neoclássico, com princípios formais tradicionais. Sua estrutura, de maneira geral, pós tonal, impregnada de nacionalismo musical não ortodoxo, se utiliza de recursos extraídos das matizes populares urbanas brasileira e norte americana." (CAVALCANTE, 2002)

Certos casos de cromatismo, em que as relações intervalares dos acordes permanecem iguais, parecem atestar a sua origem nas peculiaridades da escrita idiomática para violão que se utiliza nos

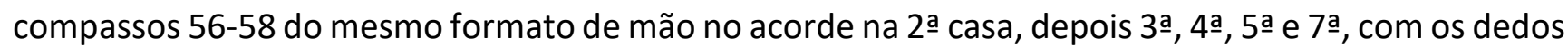
1,3 e 4 .

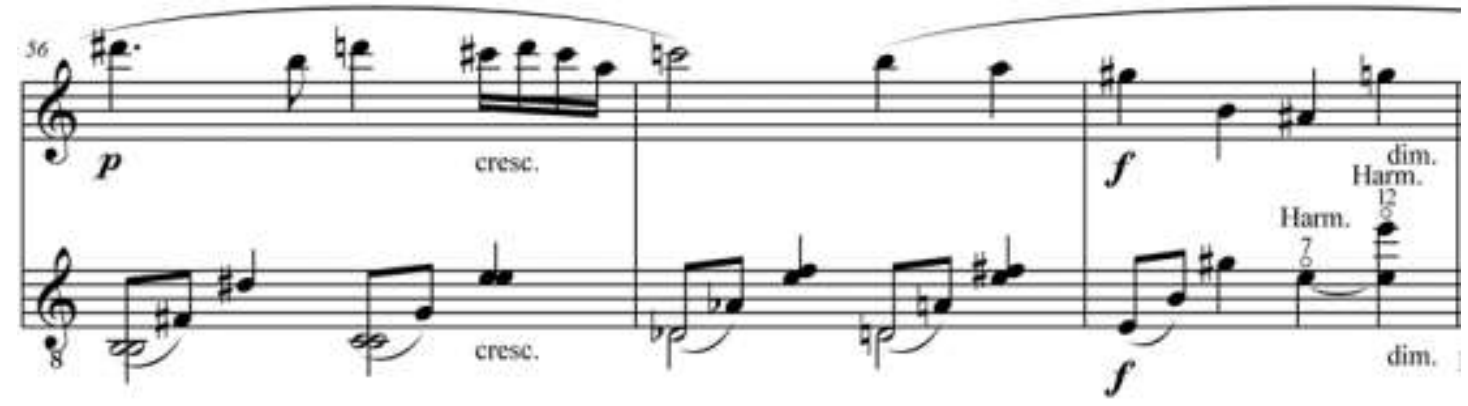

FIGURA 5 - Cromatismo atestando as peculiaridades idiomaticas do violão nos compassos 56-58

Uma interessante passagem para a flauta sugere uma escrita polifônica a duas vozes cromáticas:

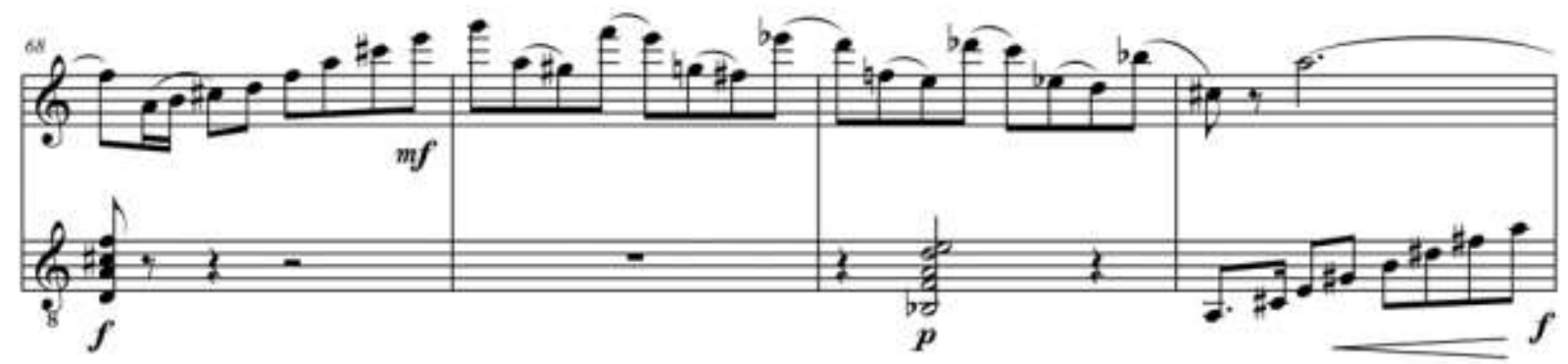

FIGURA 6 - Flauta a duas vozes cromáticas.

Na passagem acima o último acorde do violão pode ser entendido com a ênfase de um break ${ }^{4}$, deixando a flauta livre para uma pequena cadência.

A utilização de baixo pedal utilizado em seções com função de introdução ou transição (SANTOS,2002), é usado na seção de transição do tema A para o tema B (Compassos 33-37). 
Gnattali indicou o andamento com a expressão "Cantando com simplicidade", com a semínima a 126 bpm, ocorrendo apenas duas passagens em "Lento", no meio do movimento, em que a semínima é indicada a 84 bpm, sendo ambas imediatamente seguidas por trechos em "Tempo primo".

Sobre o estilo composicional de Gnattali, Estrela (1946) afirma que: "Sua harmonização é sempre bem cuidada, interessante. Sua rítmica, denotando um traço quotidiano com o elemento popular é engenhosa no arranjo de síncopas e contratempos".

Radamés tocava violão o suficiente para saber como chegar ao máximo de efeito com o mínimo de complicação, característica esta observável no primeiro movimento, onde o autor explicita uma certa simplicidade rítmica, eventualmente movimentada por tercinas (compasso 78), sem muitas síncopas e contratempos, apresentadas mais no tema B. (compassos 45-50).

\section{CONCLUSÃO}

Essa Sonatina foi escolhida, dentre outras composições, por ter sido escrita por um dos compositores mais importantes da música brasileira do século XX e por fazer parte do repertório camerístico escrito para flauta e violão. Ela possui características marcantes do estilo de Gnattali tais como a improvisação, melodias densas e resquícios de influências jazzísticas que puderam ser confirmadas na análise do primeiro movimento. Para o intérprete, é importante conhecer a técnica composicional da obra a ser executada, no intuito de compreender seu idioma, constituição e estrutura. A proposta desse trabalho foi justamente realizar um encontro da análise com a execução musical.

A Sonatina para flauta e violão de Radamés Gnattali é uma preciosa contribuição ao repertório camerístico para flauta e violão. E com esse estudo pretendeu-se, reafirmar a importância desse repertório para a música de câmara brasileira e o domínio da escrita idiomática de Gnattali para esses instrumentos. É nossa intenção de que esse trabalho possa servir de base para estudos posteriores relacionados à música de câmara brasileira e a reflexões relacionadas à performance. 


\section{REFERENCIAS BIBLIOGRAFICAS}

CAVALCANTE, Jairo José Botelho. Radamés Gnattali e o violão. (Dissertação de mestrado) Escola de Comunicações e Arte. Universidade de São Paulo. São Paulo, 2002.

COLI, Jorge. O que é arte. São Paulo. Brasiliense, 1990.

GERLING, Cristina. Considerações sobre a análise schenkeriana, in: Caderno de Estudo - Análise Musical no 2. São Paulo, Atravez, 1990.

GNATTALI, Radamés. Sonatina for flute and guitar. Heidelberg: Chanterelle Verlag, 1997. Flauta e violão.

GNATTALI, Roberto. Catálogo Digital Radamés Gnattali: Olhar Brasileiro, 2005. CD-ROM.

KOELLREUTTER, H. J. Análise Fenomenológica do Minueto em Sol Maior de J. S. Bach, In: Análise Musical no 1. São Paulo, Atravez, 1989.

MAGNANI, Sérgio. Expressão e comunicação na linguagem da música. Belo Horizonte, UFMG, 1989.

MENDONÇA, Gustavo da Silva Furtado de. A guitarra elétrica e o violão: o idiomatismo na música de concerto de Radamés Gnattali. (Dissertação de mestrado) Rio de Janeiro: Unirio, 2006.

MOLINO, Jean - Analyser, in: Analyse Musicale - 3 trimestre 1989.

PIENCIKOWSKI, Robert. Encontro com Robert Piencikowski in: Caderno de Estudo: Análise Musical n 응 2. São Paulo: Atravéz, 1990. Entrevista concedida a Yara Caznok.

WEBER, Max. Os fundamentos racionais e sociológicos da música. São Paulo: Edusp, 1995.

ZANON, Fábio. O violão no Brasil depois de Villa-Lobos. Artigo publicado no fórum de violão erudito em Maio de 2006. Disponível em: <http://p2.forumforfree.com/1-vt1436violaoerudito.html?start=0> Acesso em: 07 dez. 2006.

ZANON. Fábio. Violão com Fábio Zanon .O Violão Brasileiro, nossos compositores - Radamés Gnattali 100 anos.Cultura FM - 2006 Disponível em: http://vcfz.blogspot.com/2006/12/ndice-o-violobrasileiro.html 


\section{NOTAS}

Nota 1

Esse catálogo também se encontra disponível na internet na página:

http//:www.radamesgnattali.com.br.

Nota 2

Foi observado a utilização dessa edição em master class com o flautista Marcelo Barbosa $(\mathrm{BH}, 2006)$ e através do Prof. Dr. Mauricio Freire verificou-se que o flautista José Ananias também se utiliza dessa edição.

Nota 3

Sem terça.

Nota 4

Break - [Inglês] Durante a execução de uma peça, momento em que todos os integrantes do conjunto param de tocar, exceto um deles, que executa um solo. 


\section{Capítulo 6}

doi $10.37423 / 210604408$

\section{A TEMPESTADE: O TEATRO POLÍTICO DE AUGUSTO BOAL}


Resumo: Augusto Boal, nascido no Rio de Janeiro em 1931, destaca-se pela inovação no teatro brasileiro e mundial. Criador do Teatro do oprimido, Boal sofreu perseguição política que o conduziu à prisão e ao autoexílio na década de 1970. Nesse período, os movimentos sociais latino-americanos eram severamente reprimidos e cerceados de liberdade pelas ditaduras civil-militares. Dentro desse contexto, observando a influência do Teatro do Oprimido, esse artigo apresenta a relação dialética que a obra A tempestade, de Augusto Boal, estabelece com seu momento histórico, suas experiências teatrais e transformações sociais pretendidas com essa releitura de Shakespeare. Nessa releitura, dentro desse contexto anticolonialista, observaremos a influência do Teatro do Oprimido, apresentando a relação dialética que a obra $A$ tempestade, de Augusto Boal, estabelece com seu momento histórico, suas experiências teatrais e transformações sociais pretendidas. Acrescenta-se ainda a inquietante busca por diálogos através da arte, que possibilitem uma maior interação do público com a realidade do momento político social brasileiro, na época do regime militar. A realização dessa pesquisa leva em conta os pressupostos teóricos discutidos por Boal (2009, 2001, 2000, 1979, 1977), Césaire (2002), Freire (1970) e outros. Esse estudo revela que, a partir de Skakespeare, Boal evidencia uma capacidade de pensar a forma teatral como fenômeno histórico, aberto, cambiante, passível de emendas e adequações no mesmo ritmo das transformações sociais. Isso torna, portanto, a obra capaz de estimular não só a mudança do status quo, mas também a extrapolação do teatro.

Palavras-chave: Boal. A tempestade. Teatro do Oprimido. Shakespeare. 
Augusto Boal, nascido no Rio de Janeiro em 1931, destaca-se pela inovação no teatro brasileiro e mundial. Criador do Teatro do oprimido, sofreu perseguição política que o conduziu à prisão e ao autoexílio na década de 1970, atuou como romancista, professor, teórico, escritor, dramaturgo, encenador e diretor de teatro, durante toda a sua trajetória artística, no cenário brasileiro e estrangeiro. Bastante perseguido durante o regime militar no Brasil e diante de ameaças, decretou o seu autoexílio, ficando fora do país no período de 1971 a 1986. Já no Brasil, continuou a proposta do Centro de Teatro do Oprimido (CTO).

Boal sempre afirmou suas influências teóricas e metodológicas no seu trabalho artístico, que seriam Aristóteles, Brecht, Marx e muitos outros pensadores "inteligentes - não só os letrados como os analfabetos". (Almada, 2004).

Boal sempre procurou entender a realidade social, apostando na sua transformação por intermédio da arte. A arte está, então, "inserida" no processo histórico do qual ela é parte ativa, como afirma (Williams, 1979).

Nessa releitura, dentro desse contexto anticolonialista, observaremos a influência do Teatro do Oprimido, apresentando a relação dialética que a obra $A$ tempestade, de Augusto Boal, estabelece com seu momento histórico, suas experiências teatrais e transformações sociais pretendidas. Acrescenta-se ainda a inquietante busca por diálogos através da arte, que possibilitem uma maior interação do público com a realidade do momento político social brasileiro, na época do regime militar.

As perseguições políticas fizeram uma profunda mudança no que se refere a política cultural. A censura às manifestações artísticas que era vista como meio de propaganda política. Através da arte, grupos como o Arena, passam a discutir a condição social e passam a propagar a ideia de liberdade de pensamento em oposição à contracultura estrangeira. Muitos artistas fizeram parte de movimentos que foram severamente combatidos pela ditadura militar. (Boal, 2009).

Augusto Boal, então participante ativo do Grupo arena, parte para o enfrentamento direto com o sistema vigente repressor. Muitas montagens teatrais de protesto contra a ditadura militar mostravam as mazelas sociais pediam por mudanças e fim da repressão. Ideias de liberdade adentravam ao movimento artístico cultural em prol da resistência à repressão militar.

Esse artigo aborda o momento histórico em que $A$ tempestade de William Shakespeare é adaptada por Augusto Boal e como se imprime a sua concepção anticolonialista. Objetiva-se realizar um 
levantamento de observações, recorrendo a fontes do Próprio Boal e de estudiosos de sua obra artística, antes e depois do exílio na década de 70. Período esse em que os movimentos sociais latino americanos eram severamente reprimidos, já perdiam força frente ao imperialismo norte americano e eram cerceados de liberdade pelas ditaduras civil-militares.

Investigamos também a influência do teatro do oprimido, suas experiências e maneiras de fazer teatro em prol da transformação social. Como essas práticas, contestações, situações de opressão, através da cena, eram compartilhadas com a plateia e como as buscas de soluções geravam atuações políticas nessa participação crítica na cidadania participativa.

Na adaptação de Boal de $A$ tempestade de Shakespeare, percebe-se um certo cuidado de não extravio do texto original, mas imprime, a esta, novos significados. Alguns aspectos fundamentais foram acrescidos na adaptação, de forma a evidenciar a condição político-histórica vivida por Boal, no exílio, na década de 1970 .

O plano simbólico, tão insistentemente pesquisado por Boal, inseria ao texto de Shakespeare uma narrativa, como espaço de representação, das condições vividas pelos latino-americanos e a relação da influência imperialista ditatorial. Surgia assim, uma retomada de consciência da subalternidade dos povos latinos em detrimento das influências "colonialistas" do capitalismo selvagem.

O discurso da ação do colonizador sobre o colonizado, esse "homem do povo" é quase sempre, entre nós, um "nobre renegado", esse homem das "sociedades esvaziadas de si próprias, de cultura espezinhadas, de instituições minadas, terras confiscadas, de religiões assassinadas, de magnificência artística aniquiladas, de extraordinárias possibilidades suprimidas". (Césaire, 1978).

Esses povos oprimidos, arrancados de suas crenças e do seu modus-vivendi, a quem Boal direciona a sua proposta dramatúrgica, essa proposta dilatada, de intenções sócio-políticas, numa provocadora "mise en scène" teatral. O teatro como mecanismo de exacerbação da discussão do momento político e a condição social da vida de todo um povo. Boal explicita todo um momento tumultuoso, não só da situação política brasileira, mas também da própria condição e de sus família no exílio. Nesse período produz grande parte de suas técnicas não institucionais, Cria novas possibilidades do fazer teatral com foco para uma nova pedagogia e atrai novos participantes.

A tempestade de boal surge trazendo personagens mais simbólicos e acentuando ainda mais, um certo engajamento político. Caliban - o representante das massas oprimidas e manipuladas pelo 
imperialismo. Ariel, o subalterno a serviço da ordem vigente, uma espécie de "capitão do mato" a disposição do "senhor de engenho".

O Teatro do oprimido sempre teve o intuito de promover debates para obtenção de respostas e impelir os agentes da coletividade a uma postura ativa e dinâmica. (Boal, 2009). A tempestade Shakespeareana migra para uma obra recheada de original ambientação para o campo simbólico da cena inaugurando uma nova linguagem metateatral. Vislumbra-se um Próspero regente, um organizador do espaço cênico, um extrapolador. Do outro lado, Caliban, um injustiçado e inadaptado à sua condição de colonizado, instaurando à cena política assumidamente contestadora.

Boal, na sua proposição alegórica, não se distancia muito do formato shakespeariano, mas mescla sua dialética político social a processos histórico latino americano, tendo como base toda a carga teórica da Pedagogia do oprimido, abordada por Paulo Freire. Essa mistura que abrange o contexto histórico, a realidade social vigente com a tentativa de se chegar a um público oprimido carente de narrativas alegóricas que mexam com a sua realidade social.

Quando Boal propôs o Teatro do oprimido, ele já tinha mantido contato com a Pedagogia do oprimido de Paulo Freire em que explicou a importância da necessidade de uma pedagogia dialógica e emancipatória do oprimido em oposição a pedagogia da classe dominante para que promovesse a libertação e transformação do sujeito, dono de sua própria história. (Freire, 1970).

O educador, na concepção de Paulo Freire, deve proporcionar uma educação dialógica em que o povo oprimido passe a ser agente do seu próprio universo, adquirindo capacidades para a transição da "consciência ingênua" para a "consciência crítica". Surge então, um movimento de liberdade a partir da lógica do oprimido que luta pela sua humanidade e concretiza a sua pedagogia.

Essa pedagogia de Paulo Freire implica em atitudes e posicionamentos radicais, em que o povo, através do diálogo, é colocado como instrumento fundamental para permitir uma leitura crítica da realidade com sua própria linguagem. Esse povo possuidor de valores, vivências e de sua própria visão de mundo e que transforma tudo isso em luta verdadeira pela libertação dos oprimidos.

A postura de Boal assumida diante a estética do Teatro do oprimido possui uma incontestável relevância para o cenário pós-colonialista. O trabalho observado com o teatro do Arena em São Paulo, tornou-se uma eficaz experimentação de ideias para que se estabelecesse e se configurasse um teatro puramente brasileiro. Nesse cenário em que se pretendia um público politicamente informado e consciente de força e voz, sendo encorajado a vislumbrar o poder de participação nos 
desdobramentos da nação. (Boal, 2000). Existia a perspectiva de alcançar um "status quo" e com o advento do golpe de 1964 tinha-se que arranjar um meio de enganar a censura.

Boal com a sua adaptação de $A$ tempestade de William Shakespeare, intensifica, dentro de seus propósitos, a impressão da sua visão reformista. Diferente do seu teor universal de colonização na obra shakespeariana, Boal opta por uma linguagem carregada de alegorias e assume uma localização da trama desenvolvida e propõe uma oposição ao colonialismo cultural. (Boal, 2000, p. 176). Como engendrar uma missão que desestabiliza um ícone cultural e imprime uma adaptação tão diferenciada do seu original, nesse sentido.

Na primeira parte do texto de Boal, percebemos um certo embate dos marinheiros e o grupo de nobres em meio a tempestade. A separação entre as classes fica definida, mas Boal acrescenta uma certa ironia ao passar o controle para quem mais entende de navegação, no caso, os comandantes do navio. Sendo assim, a classe dos senhores tenta impor a sua nobreza, porém a subalternidade está no comando da sorte de todos e faz valer o que interessa naquele momento:

[...]

MARINHEIROS - Cuidado! Cuidado! - Vamos encalhar! - Soltem as velas! - Rema, rema! - Serenidade! - Ciclones! Furacões! - Tempestade! Tempestade!

CAPITÃO - Voltem vossas mercês aos vossos camarotes! ANTÔNIO - Senhor: Somos fidalgos!

CAPITÃO - Mais vale um plebeu que me ajude a cem nobres que me encham o saco!

ANTÔNIO - Animal! Sabes que é este?

FERNANDO - Sou o filho do Rei!

CAPITÃO - Está de parabéns!

ANTÔNIO - E este, sabes quem é?

SEBASTIÃO - Sabem quem sou? ... ainda que não o pareça? CAPITÃO - Sabemos de sobra.

ANTÔNIO - É o irmão do Rei!

CAPITÃO - Que sorte!

REI ALONSO - E eu? Sabes quem é a minha real pessoa? CAPITÃO - Eu vos conheço, senhor, mas se não forem todos embora, melhor vão vos conhecer os tubarões!

ANTÔNIO - É nada menos que o próprio Rei em pessoa!

REI - Ordeno pois que retorne a razão aos espíritos, que retorne o amor aos corações, e que retorne enfim a calma a estes mares! Sendo quem sou, ordeno que cesse a Tormenta! Que as apaziguem as ondas e serenem os ventos! 
CAPITÃO - Senhor, eu ordeno que retornem Vossas Mercês aos vossos camarotes! Nós sabemos quem sois, mas a tempestade não! E o furacão não conhece realeza!

REI - Se assim é, gravemente se terá enganado a tempestade!

[...] (Boal, 1979, p. 12).

Boal se familiariza proposta por Shakespeare e nos liga quase que intimamente às situações recriadas. Convida-nos a vivenciarmos situações (Dos desmandos da ditadura) próximas a realidade vividas por seus expectadores, Seria uma aparente derrota, porém sugere uma investida dos oprimidos, para que obtenham consciência da luta necessária e acirrar os ânimos diante de uma eminente derrota. Seria Boal um possuidor da "varinha" de Próspero? O seu ideal seria possível? Para ele certamente a reflexão provocaria mudanças e serviria de alerta para o comportamento amoral e hipócrita ao lamentar o seu infortúnio. Próspero reivindica o seu ducado e lamenta a injustiça do seu irmão, mas ao mesmo tempo escraviza, humilha os seres da ilha para vingar-se dos nobres e conseguir o seu intento:

$[\ldots]$

CALIBÁN (DE DENTRO) - Tem muita lenha aí dentro. Basta explorador miserável.

PRÓSPERO - Vem assim mesmo, sapo repugnante! Tem mais trabalho pra fazer! Tem mais trabalho para fazer! (ENTRA ARIEL VESTIDO DE NINFA DO MAR, ETÉREO, BAILANDO COM MÚSICA). Que sublime aparição. Desde que eu quero te dizer uma coisa no ouvido. (ARIEL SE APROXIMA). Bzbzbzbzbzbzbzbbzbzbzbz.

ARIEL - Assim será, meu Senhor. Ho, ho, ho! (SAI BAILANDO).

PRÓSPERO - E agora você, escravo venenoso, engendrado pelo próprio diabo no ventre de tua horrível mãe, vem que eu estou te chamando! (ENTRA CALIBÁN).

CALIBÁN - Que o ar pestilento e apodrecido de minha mãe varria com pluma de corvo no infecto pantanal caia sobre vocês dois. Que um vento de marimbondo sopre sobre vocês cobrindo suas peles de úlcera.

MIRANDA - Bzbzbzbzbzbzbz.

PRÓSPERO - Por isso que estás dizendo, os ouriços vão se alimentar da tua carne imunda. Tua pele vai ser metralhada por tantas picaduras como um favo de mel. E cada buraco vai te doer mais do que se fossem feitas pelas abelhas!

CALIBÁN - Esta ilha me pertence, e você me roubou! Quando você veio pela primeira vez, eu acreditei em você, e você me corrompeu" Me deu o supérfluo, e eu te dei minha terras. Me deu colares, espelhos e anéis, e eu te ofereci meus rios, minhas praias e meus campos. Que sobre ti caiam todas as maldições da terra! Que te matem os escorpiões, sapos e os morcegos. Você reina em minha terra e eu sou escravo em meu país!

[...] (Boal, 1979, p. 21). 
Todo o cenário Shakespeareano da transcendente ilha mística, adaptado por Boal, transforma-se para a realidade latina, bem mais próxima do entendimento do expectador. A defesa de Boal é a de que a função do teatro do oprimido faça com que os expectadores, depois de vivenciá-lo, retornem para o seu quotidiano modificados politicamente. "O teatro é uma arma e é o povo que deve manuseá-la". (Boal, 1977, p. 127). O maniqueísmo sugerido em $A$ tempestade shakespeariana confirma que os politicamente corretos são aqueles que obedecem aos seus senhores, respeitam a ordem vigente. Os contestadores são os indesejáveis, os sujos, usurpadores inescrupulosos. Caliban torna-se, então, na adaptação de Boal, a figura representante de todos os latinos nessa realidade de supressão de direitos. Ele é o perseguido, o exilado na própria pátria-amada, portanto pode se impor como membro participante ativo desse "novo mundo":

"Este espetáculo pode ser feito em palco à italiana ou em arena; em teatro ou
em circo; numa garagem ou na rua. Para mim, o importante é que seja feito
com muita verdade, muita sinceridade, muita cor, que pode até exagerar um
pouco mas que fique claro, bem claro, que somos belos porque somos nós, e
nenhuma cultura imposta é mais bela do que a nossa. É preciso que fique claro
que nós somos Calibán." (BOAL, 1977, p. 1). Caliban possui em si o espírito de combate, ele se inclina ao movimento do diálogo com a intenção de conseguir a convencer os outros a aderirem à "revolução" consciente de retomada do comando da ilha. Essa ilha simbólica representa a autêntica condição dos colonizados que estão à mercê dos infortúnios gerados pelos colonizadores e tenta juntar-se aos outros estabelecendo uma luta de classes. Propõe estratégias, abre debates e por fim, incita a invertida direta contra o opressor. Na cena em que Caliban cobra de Próspero, é forte o discurso de denúncia da influência do capitalismo selvagem em relação ao domínio das terras "colonizadas" submetidas aos desmandos dos invasores:

CALIBÁN - Você me ensinou a tua língua e eu te agradeço: assim posso te amaldiçoar certo de que você vai me compreender. (MÚSICA DE INSPIRAÇÃO NORTEAMERICANA, GRITOS, SONS, DESEPERO, GUITARRA ELÉTRICA, MUDANÇAS FEROZES DE LUZ, CALIBÁN AGARRA O MICROFONE E COMEÇA A FALAR DENTRO DO RITMO - AMBIENTE DE SHOW DE MÚSICA BEAT). Você me ensinou a tua música; obrigado - canta e dança comigo! Eu quero te amaldiçoar mas você diz que você é bom. Supondo que Próspero não fosse Próspero, que fosse outra! E supondo que esse outro, que não é Próspero, me odiasse porque sou o dono do meu país, e viesse com seus navios e bloqueasse minhas terras, e lançasse bombas de fósforo vivo para queimar as carnes dos meu irmãos e minhas irmãs, e bombas e canhões que destruíssem as casa de meu pai e minha mãe, -- se isto fosse verdade, e é verdade que pode ser - se isto fosse verdade, é certo que você cantaria junto comigo: "Que Todas as Pestes do Mundo Caiam sobre os Invasores! CALIBÁN - Você me ensinou a tua língua e eu te agradeço: assim posso te amaldiçoar certo de que você vai me compreender. (MÚSICA DE INSPIRAÇÃO NORTEAMERICANA, GRITOS, SONS, DESEPERO, GUITARRA ELÉTRICA, MUDANÇAS FEROZES DE LUZ, CALIBÁN AGARRA O MICROFONE E 
COMEÇA A FALAR DENTRO DO RITMO - AMBIENTE DE SHOW DE MÚSICA BEAT). Você me ensinou a tua música; obrigado - canta e dança comigo! Eu quero te amaldiçoar mas você diz que você é bom. Supondo que Próspero não fosse Próspero, que fosse outra! E supondo que esse outro, que não é Próspero, me odiasse porque sou o dono do meu país, e viesse com seus navios e bloqueasse minhas terras, e lançasse bombas de fósforo vivo para queimar as carnes dos meu irmãos e minhas irmãs, e bombas e canhões que destruíssem as casa de meu pai e minha mãe, -- se isto fosse verdade, e é verdade que pode ser - se isto fosse verdade, é certo que você cantaria junto comigo: "Que Todas as Pestes do Mundo Caiam sobre os Invasores!

[...] (Boal, 1979, p 25).

Enquanto Ariel é o escravo que atende executa as ordens de Próspero e segue auxiliando a manutenção do comando do maestro colonizador, por outro lado, Caliban monta estratégias para derrubar o poder do seu senhor, agilizando um complô com os outros. A luta coletiva torna-se necessária para a derrubada do regime "imperialista", somente a união de forças conscientes é capaz de fazer ruir o poder de Próspero. Percebemos a tentativa de Boal de colocar a sua arte política e transformadora através de reflexões geradas pela prática do dialogismo do teatro do oprimido, que revigora a postura do sujeito "colonizado" através da elevação da sua consciência política. Combatese a incorporação da cultura do "colonizador' em defesa da cultura latino-americana. O propósito de disseminar esse pensamento, acredita Boal na sua adaptação, pode abrir esperança na mudança do "status quo". A força ideológica impressa em Caliban ao deparar-se com seus companheiros, obedientes e resignados aos seus senhores, aceitando totalmente a dialética do "colonizador" ao ponto de defender e aceitar como única saída pra os subalternos, ele contra-ataca:

CALIBAN - Você é um vendido que se entrega de corpo e alma para defender o invasor.

TRÍNCULO - (GRITA DE FORMA CASTRENSE) A-tem-ção! Le-var le-nha ao fo-go! Hoje meu senhor prepara uma grande festa. (DÁ UMA CHICOTADA).

CALIBAN - Escuta, desgraçado: porque é que você serve ao teu senhor?

TRÍNCULO - E a que senhor teria que servir se não ao meu? CALIBAN - A ti mesmo.

TRÍNCULO - Meu senhor é muito poderoso, é melhor obedecê-lo.

CALIBAN - Você não percebe, traidor miserável, que ele só é forte porque usa o teu braço? Sua força é a tua força. Você tem medo do chicote que você mesmo empunha?

TRÍNCULO - Assim são os costumes. Eu estou acostumado a obedecer, obedeço.

CALIBAN - E porque não obedece a mim? Você não percebe que você é meu irmão? Por que não me obedece a mim e juntos estrangulamos o tirano?

TRÍNCULO - Não. Esse é o costume: eu necessito um senhor. A-ten-ção! 
CALIBAN - (GRITA) Eu sou o teu senhor! Ordeno que você mate o invasor Próspero!!!!

TRÍNCULO - Não posso. Eu deveria estar acostumado a obedecer ao meu irmão e não estou. Teria que estar acostumado a estas transformações.

CALIBAN - Puta merda, que você disse a verdade. As pessoas precisam se acostumar as transformações. Você tem toda a razão. Mas, caramba, é preciso começar.

TRÍNCULO - Vamos ver, comecemos.

CALIBAN - Responde minha pergunta: que diferença existe entre mim e o teu senhor?

TRÍNCULO - Existem muitas. Ele tem mais autoridade. CALIBAN - Assim? (IMITA A PRÓSPERO).

TRÍNCULO - Um pouco mais.

CALIBAN - Assim?

TRÍNCULO - Na verdade, parece que sim.

CALIBAN - Então, começa a transformação. Eu ordeno morte ao invasor!

[...] (Boal, 1979, p. 70).

Boal, ao adaptar a obra de Shakespeare nos remete ao lugar, apresentando uma rede de estratégias revolucionárias de uma mudança que, em seu início, pareceu possível, mas que, ao fim e ao cabo, mostrou-se incapaz de emergir do estado de marasmo em que se encontra, até hoje. A complexidade da condição política que o próprio vivia e que permeia de muitas perguntas do nosso pensamento crítico. Essa paródia simbólica apontada por Boal, reflete a derrota vivida pela esquerda na época, dando-nos uma visão em forma de restropecto histórico da tentativa fracassada do apregoamento de um credo político revolucionário. As simbologias, tão eficientes, para nos fornecer as intenções tão interessantes do processo do teatro do oprimido, chega a nos paralisar no tempo e nos acalenta para a força da arte de aproximação de um momento, tão complexo da história do Brasil.

A tempestade de Boal não deixa de evidenciar em si mesma uma capacidade de pensar a forma teatral como fenômeno histórico, aberta, cambiante, passível de emendas e adequações no mesmo ritmo das transformações sociais, que acaba mergulhando na complexidade mais que real da condição política do país e do próprio Boal, permeando o nosso pensamento crítico.

As simbologias tão eficientes por nos fornecer as intenções tão interessantes do processo do Teatro do oprimido, chega, nos paralisa no tempo e nos acalenta para a força da arte de nos aproximar de um momento histórico tão complexo para o Brasil, na época.

A adaptação de Augusto Boal termina sendo capaz de, a um só tempo, estimular a mudança do status quo e brotar dessa mesma mudança, já diferente do que era, a extrapolação do teatro. Ao todo, $A$ 
tempestade não deixa de evidenciar em si mesma uma capacidade de pensar a forma teatral como fenômeno histórico, aberta, passível de emendas e adequações no mesmo ritmo das transformações sociais. Mas no final a regra básica da manutenção da ordem vigente é sinalizada e transparece uma derrota eminente dessa dialética transformadora, ou seria um alerta para que o expectador se sentisse incomodado e passasse a querer assumir a postura de sujeito revolucionário? 


\section{REFERÊNCIAS}

BOAL, Augusto. Técnicas latino-americanas de teatro popular. Coimbra: Centelha, 1977. A tempestade e As Mulheres de Atenas. Lisboa: Plátano, 1979.

Teatro do oprimido e outras poéticas políticas. Rio de Janeiro: Civilização Brasileira, 1980. Hamlet e o filho do padeiro. Rio de Janeiro: Record, 2000. . Exilado. In Caros amigos. Março de 2001. A estética do oprimido / Augusto Boal. - Rio de Janeiro: Garamond, 2009.

ALMADA, Izaías. Teatro de arena. Uma resistência. São Paulo: Boitempo, 2004.

WILLIAMS, Raymond. Marxismo e literature. Rio de Janeiro: Zahar, 1979.

CÉSAIRE, Aimé. Discurso sobre o colonialismo. 1ạ edição. Livraria Sá da Costa. Editora Lisboa, 1978. FREIRE, Paulo. Pedagogia do oprimido. Rio de Janeiro: Paz e terra, 1970. 


\section{Capítulo 7}

doi) $10.37423 / 210704419$

\section{LÍNGUA ESTRANGEIRA, CURRÍCULO E MOTIVAÇÃO DOCENTE: UMA ANÁLISE DA PERCEPÇÃO DE ENSINO DE INGLÊS NOS ANOS FINAIS DO ENSINO FUNDAMENTAL}

Rackel Peralva Menezes Vasconcellos

Poliana Campos Côrtes Luna

\section{Lucas Capita Quarto}

\section{Cristiana Barcelos da Silva}

Carlos Henrique Medeiros de Souza

Maria Eliza Guimarães Tavares

Cristina Pereira Gomes de Azeredo
Universidade Estadual do Norte Fluminense Darcy Ribeiro

Universidade Estadual do Norte Fluminense Darcy Ribeiro

Universidade Estadual do Norte Fluminense Darcy Ribeiro

Universidade/Estadual do Norte Fluminense Darcy Ribeiro

Universidade Estadual do-Norte Fluminense Darcy Ribeiro

Instituto Crispi de Cirulgia Minimamente Invasiva

Grupo Educacional Censupeg 
Resumo: Muito se tem discutido sobre uma aprendizagem significativa, que envolva o aluno. Definitivamente, para que esse processo se dê é preciso reconhecer a peça -chave no direcionamento da Educação: o professor. Talvez uma questão a ser pensada, seria o fato de que em sua grande maioria, as salas de aulas ainda têm a mesma estrutura e utilizam os mesmos métodos usados na educação do século XIX: as atividades ainda são baseadas quadro e papel, e o professor continua ocupando a posição de protagonista, detentor e transmissor da informação. Essa prática, nas aulas de Língua Inglesa, fica ainda mais evidente. Isso ocorre principalmente em escolas públicas onde, a relação ensino-aprendizagem do inglês é observado com preconceito, na qual os professores, em sua maioria, consideram que os alunos são incapazes de aprender outro idioma, uma vez que, possuem dificuldade de aprender o próprio português. No ano de 2012 foi implantado pelo Governo do Estado do Rio de Janeiro o Currículo Mínimo, um documento que objetiva nortear o trabalho dos profissionais da educação, orientando-os na elaboração e desenvolvimento de suas aulas. O presente trabalho pretende analisar a implementação do Currículo Mínimo de Língua Inglesa na rede estadual de Educação do Rio de Janeiro.

Palavras-chave: Língua Estrangeira. Currículo. Motivação Docente. 


\section{INTRODUÇÃO}

Pensar numa educação de simples transmissão, que fique restrita a sala de aula, leva a um conhecimento superficial que, quando acontece, aparece de forma pouco prática, distante da realidade do educando - o professor transmite e o aluno escuta. O que nos leva a uma aprendizagem reprodutiva e bancária.

Definitivamente, para que esse processo se dê é preciso reconhecer a peça -chave no direcionamento da Educação: o professor. Diante da essencialidade da influência do professor no percurso educacional, muita atenção precisa ser reservada a esse protagonista da condução do conhecimento e da formação de crianças, jovens, adultos e até mesmo idosos.

Talvez uma questão a ser pensada seria o fato de que em sua grande maioria, as salas de aulas ainda têm a mesma estrutura e utilizam os mesmos métodos usados na educação do século XIX: as atividades ainda são baseadas quadro e papel, e o professor continua ocupando a posição de protagonista, detentor e transmissor da informação. Essa prática, nas aulas de Língua Inglesa, fica ainda mais evidente. Quantas vezes, um professor de Inglês ouve na primeira aula: "Lá vem o verbo to be!" E pouco se vai além do dito "verbo to be".

Para muitos professores de inglês, não existe a preocupação pela formação social do aluno. Nem sempre as discussões giram em torno das atitudes dos alunos no convívio social. Parece que a missão de educar se delega as disciplinas básicas no ensino regular e as famílias.

Isso ocorre principalmente em escolas públicas onde, a relação ensino-aprendizagem do inglês e observado com preconceito, onde os professores em sua maioria consideram que os alunos são incapazes de aprender outro idioma, uma vez que, possuem dificuldade de aprender o próprio português. O professor não deve ser um mero transmissor de conteúdo mais sim um profissional que envolve; expressa e constrói apreciações.

Durante anos, muito se discutiu sobre o conteúdo abordado por cada professor na sala de aula, a discrepância do currículo abordado em cada escola estadual. Com base nessas discussões, no ano de 2012 foi implantado pelo Governo do Estado do Rio de Janeiro o Currículo Mínimo, um documento que objetiva nortear o trabalho dos profissionais da educação, orientando os professores na elaboração e desenvolvimento de suas aulas.

Sua finalidade é que o aluno tenha o mínimo de competência e habilidade durante cada bimestre ao longo do ano letivo; assim se o aluno for transferido de colégio, o conteúdo mínimo será o mesmo. 
Além das competências e habilidades, o Currículo Mínimo também propõe atividades para serem feitas com os alunos em sala de aula ou como atividade extraclasse.

Ao passo que o currículo mínimo foi criado e exposto como obrigatória a aplicação - por parte dos professores, a resistência foi imediata. Se bem analisado, é um documento interdisciplinar que aplica o uso da língua na compreensão oral e escrita. A resistência por parte do educador advém do fato do mesmo, muitas vezes, não saber trabalhar a língua nesse formato. Dessa forma, ignora-se a existência do documento, seguindo o seu plano de trabalho.

O presente artigo pretende analisar a implementação do Currículo Mínimo de Língua Inglesa na rede estadual de Educação do Rio de Janeiro - bem como os impactos e possíveis modificações no trabalho realizado pelos professores de Língua Inglesa da rede.

\section{REVISÃO LITERÁRIA}

A grande influência econômica, política e cultural dos Estados Unidos, seguida de fortes investimentos, tornou o Inglês uma língua internacional, alcançando reconhecido prestígio mundial e passando a fazer parte do cotidiano das escolas nacionais e internacionais. Com o tempo, o ensino do inglês passou a fazer parte da grade curricular das escolas no Brasil, a despeito da realidade de cada região do país. Quando a Lei de Diretrizes e Bases da Educação, LDB 9.394/96, Art. 36, § III, determinou que o currículo do Ensino Médio incluísse uma língua estrangeira obrigatória e uma optativa, a maioria das escolas estabeleceu a língua inglesa como a obrigatória (processo de naturalização).

Conforme salienta Mendes (2007), a importância do aprendizado de uma língua estrangeira está na possibilidade de se ter condições de dialogar com grupos ou pessoas que falam outras línguas e que vivem em sociedades diferentes.

Nesse sentido, a elaboração de um currículo deve estar ancorada às propostas didático-sociais e culturais adequadas aos níveis de escolaridade e que atendam às condições reais para o desenvolvimento de habilidades como o senso crítico, a ética e a cidadania.

O currículo nunca é simplesmente uma montagem neutra de conhecimentos, que de alguma forma aparece nos livros e nas salas de aula de um país. Sempre parte de uma tradição seletiva, da seleção feita por alguém, da visão que algum grupo tem do que seja o conhecimento legítimo. Ele é produzido pelos conflitos, tensões e compromissos culturais, políticos e econômicos que organizam e desorganizam um povo (APPLE, 2001, p. 53). Veiga (2002, p.7) complementa: 
Currículo é uma construção social do conhecimento, pressupondo a sistematização dos meios para que esta construção se efetive; a transmissão dos conhecimentos historicamente produzidos e as formas de assimilá-los, portanto, produção, transmissão e assimilação são processos que compõem uma metodologia de construção coletiva do conhecimento escolar, ou seja, o currículo propriamente dito.

Em 2011, a Secretaria Estadual de Educação do Estado do Rio de Janeiro (SEEDUC) decidiu implantar na rede estadual a proposta curricular do Currículo Mínimo, de base comum, que direcionasse as atividades educacionais de maneira a aproximar e nortear o aprendizado na rede estadual. Em um primeiro momento, o Currículo Mínimo das disciplinas língua portuguesa e literatura, matemática, geografia, filosofia e sociologia foi elaborado para o ensino fundamental e médio das turmas regulares. No ano seguinte se iniciou a elaboração do Currículo Mínimo para as disciplinas de educação física, biologia, física, química, educação artística, ensino religioso e língua estrangeira para turmas dos mesmos segmentos citados anteriormente.

É, nesse campo prático e complexo em que se insere o Currículo Mínimo para as línguas estrangeiras modernas, elaborado por professores da SEEDUC/RJ, instituído pelo Decreto no. 42.793 de 06 de janeiro de 2011.

De acordo com o manual do currículo mínimo desenvolvido pela SEEDUC (BRASIL,2010) a proposta para LE (Língua Estrangeira) é promover, inicialmente, a interdisciplinaridade com a língua materna (para tal, sempre que possível, seguirão a abordagem de ensino por gêneros similar à adotada por Língua Portuguesa), mas a interdisciplinaridade com todas as demais áreas poderá ser suscitada a partir das temáticas introduzidas pelos gêneros. De acordo com o manual, alguns documentos referenciais externos foram utilizados na elaboração do material, bem como o conjunto de documentos de orientação do MEC como LDB, Diretrizes Curriculares Nacionais, Parâmetros Curriculares Nacionais e Orientações Curriculares Nacionais e a matriz da avaliação externa do Exame Nacional do Ensino Médio.

O Currículo Mínimo de Língua Estrangeira é composto por três eixos principais, sendo eles: "Compreensão escrita e oral", "A língua em uso" e "Produção escrita e oral". Foram também definidas as habilidades e competências que deveriam ser galgadas pelos educandos em cada um dos gêneros elencados.

Segundo as Orientações Curriculares Nacionais para o Ensino Médio (OCEM, 2006, p. 9), "o currículo é a expressão dinâmica de conceito que a escola e o sistema de ensino têm sobre o desenvolvimento dos seus alunos e que se propõe a realizar com e para eles", portanto, torna-se necessário refletir a 
relevância de uma proposta curricular para o sistema educacional que tenha como propósito ensinar, envolver, preparar para a cidadania e produzir conhecimento.

Diante da introdução de um currículo mínimo para as línguas estrangeiras nas escolas da rede pública estadual, fomentou-se a importância da relevância das orientações para o fazer docente e para o processo ensino/aprendizagem de língua estrangeira.

O Currículo Mínimo foi imposto aos professores pelo Governo do Estado como algo obrigatório sob pena de não recebimento de bonificações para aqueles que não o colocarem em prática em sala de aula. As dúvidas referentes à implementação deste documento em sala de aula são constantes e a resistência é ainda maior. Segundo Piccoli $(2006$, p.2):

Percebe-se que o professor de língua estrangeira mantém-se afastado do contexto educacional propriamente dito e preocupa-se apenas em transmitir os conteúdos lingüísticos. Esses professores têm evitado considerar o ensino de língua estrangeira como parte relevante da educação integral do ser humano, desconhecendo muitas vezes as razões e os porquês do ensino de pelo menos uma língua estrangeira como aspecto fundamental na educação de sujeitos.

Conforme apontado pela Organização das nações unidas para educação, Ciência e Cultura(UNESCO), professores de todos os níveis e tipos de educação devem ser capacitados, em termos do seu desenvolvimento profissional contínuo, incluindo o uso apropriado da tecnologia, aprendizagem em pares, avaliação e trajetórias de carreira claras com incentivos intelectuais, reconhecimento social e autonomia profissional. (UNESCO,2015)

Para que aconteça a concretização do aprendizado é preciso que o educador seja um mediador entre o conteúdo de Língua Estrangeira proposta pelo Currículo Mínimo e o educando, transpondo para as aulas conteúdos de forma simplificada, contextualizada e com uma linguagem apropriada para o entendimento do aluno.

\section{CONCLUSÃO}

Historicamente, a educação brasileira passou por um longo período onde os professores que atuavam na educação básica não possuíam uma formação acadêmica adequada. Foi apenas a partir do começo do século XX que apareceu a preocupação em formar professores para atuarem nos anos finais do ensino fundamental e ensino médio.

Partindo dessa premissa, é possível e necessário também a criação de ambientes de aprendizagem onde haja tanto aspectos da transmissão de informação quanto de construção. Isso posto a questão 
fundamental no processo educacional é saber como criar situações de aprendizagem para estimular a compreensão e a construção de conhecimento.

No Brasil, a Língua Inglesa é o idioma mais ensinado como língua estrangeira, e está presente em vários lugares e em diversos setores da sociedade, como em rótulos de produtos alimentícios, cosméticos, vestuário, propagandas, programas de televisão, outdoors, entre outras utilizações. Sendo assim, considerando o inglês como um meio de comunicação que abrange todas as áreas do saber, entendese que se faz necessário determinar um modelo pedagógico que respalde o ensino de língua estrangeira.

Ainda refletindo sobre o papel das línguas estrangeiras modernas, que não estão entre as disciplinas consideradas mais importantes nas escolas (nem por alunos, nem pela comunidade escolar), não podemos ignorar sua importância no contexto globalizado, que busca preparar o cidadão/aluno para relacionar-se com o outro (o estrangeiro), interagir, fazendo-se compreender e ser compreendido em uma outra língua.

Desde 2011, ano em que o Estado discutiu e elaborou um currículo mínimo para servir de base curricular para todas as escolas da rede estadual, os professores, que não foram treinados, preparados para esse tipo de trabalho interdisciplinar, voltado para o desenvolvimento da leitura e escrita livre do segundo idioma, rejeitou o material apresentado.

Nesse sentido, cabe à escola, na figura do professor, fazer a releitura da proposta apresentada como currículo, adequá-la ao contexto, construindo um Projeto Político-Pedagógico (PPP) que possa descrever suas funções e concretizá-las. Só assim o currículo cumpre seu papel de representar a comunidade escolar, cuja participação é de suma importância para a concretização de um currículo que tenha como objetivo atender às diversas realidades, nacionais ou estaduais.

Inúmeros questionamentos referentes ao Currículo Mínimo e sua implementação surgem nas conversas diárias entre professores da rede estadual de ensino. Há aqueles que pensam colocá-lo em prática, pois veem neste documento uma chance de transformar e melhorar a educação pública da rede estadual do Rio de Janeiro. Por outro lado, alguns professores não aceitam e/ou acreditam nessa nova política pública devido a conceitos e formas cristalizadas de desenvolvimento do seu trabalho em sala de aula, os quais não desejam modificar. Outros não pensam adaptar suas aulas às novas orientações, já que não acreditam nas "sugestões" dadas pelo Governo, que, na verdade, são recebidas como imposições. 
Outro ponto questionado pelos educadores é que os livros didáticos disponibilizados pelo Programa Nacional do Livro Didático (PNLD) - a partir dos quais a equipe de professores de cada instituição tem que fazer sua escolha antes da implantação do Currículo Mínimo - não contemplam, em sua maioria, os gêneros propostos pelo documento acima citado.

Ademais, também como orientação da secretaria estadual de educação, o conteúdo deve ser registrado no diário escolar e ser confirmado no site Conexão Educação - Docente Online que é um portal da secretaria. Entretanto lançar o conteúdo no diário ou no site, não quer dizer que estejam sendo ministrados aos alunos. Por enquanto, saber se eles estão de fato cumprindo o $\mathrm{CM}$, é algo que não pode ser comprovado. Isto posto, assim como todo modelo pedagógico, é preciso adaptação, reciclagem e reorganização, a todo momento. 


\section{REFERÊNCIAS BIBLIOGRÁFICAS}

APPLE, Michael W. Repensando Ideologia e Currículo. In: MOREIRA, Antônio Flávio B.; SILVA, Tomaz Tadeu da. (Orgs.). Currículo, cultura e sociedade. São Paulo: Cortez, 1995.

COSTA, Patrícia Paull. A implementação do PNLD de língua inglesa nas escolas públicas da Rede Municipal de Ensino de Porto Alegre. 2012. Monografia de conclusão de curso de graduação apresentada ao Instituto de Letras da UFRGS, Porto Alegre.

FREIRE, P. Pedagogia do Oprimido. Rio de Janeiro: Paz e Terra, 1996.

FREIRE, Paulo. Pedagogia da autonomia: saberes necessários à prática educativa. São Paulo: Paz e Terra, 2003.

GREEN, S. ET AL. (2011). Towards a positive university. The Journal of Positive Psychology, 6(6), pp. 432-439.

KAUARK, Fabiana. Metodologia da pesquisa: guia prático / Fabiana Kauark,Fernanda Castro Manhães e Carlos Henrique Medeiros. - Itabuna: Via Litterarum, 2010.

MORIN, Edgar. A cabeça bem-feita. Rio de Janeiro: Editora: Bertrand Brasil, 2000, p.20- 109.

PALLÚ, Nelza Mara. Que inglês utilizamos e ensinamos?: reinterpretações de professores sobre o processo de ensino e aprendizagem do inglês contemporâneo. Curitiba, 2013.

PIMENTEL, Luciana. Projetos de trabalho em educação: uma proposta de vivências interdisciplinares. In: POSSAS, Sandra. (Orgn). Inglês na sala de aula: Ação e reflexão. -1. ed. São Paulo: Moderna 2010. (Coleção Richmond reflections).

QUIRINI, Maria José da Silva de Oliveira; PEREIRA, Carlos Alexandre da Silva; LEAL, Cristianni Antunes; OLIVEIRA, Vânia Lucia. (2011) Políticas Curriculares: uma breve crítica ao Currículo Mínimo implantado no Estado do Rio de Janeiro.

SACRISTÁN, J. G., O Currículo, uma reflexão sobre a prática. Porto Alegre: Editora Artmed, 2000.

SEEDUC/RJ, Proposta Curricular: um novo formato, Língua Estrangeira, 2010, p.06. Disponível em http://www.conexaoprofessor.rj.gov.br/downloads/LINGUA_ESTRANGEIRA.pdf. Acesso em: 12 de nov. 2019.

; SHOR, Iria. Medo e ousadia. Rio de Janeiro: Paz e Terra, 1993

SNYDER, C. R., \& LOPEZ, S. J. Psicologia Positiva: uma abordagem científica e prática das qualidades humanas. Porto Alegre: Artmed,2009

http://historiadabncc.mec.gov.br/documentos/CURRICULOS/Rio_de_Jneiro_Curriculo_Minimo_201 2_Lingua_Estrangeira_Livro.pdf Acesso em 12 de nov.2019

UNESCO. Educação: um tesouro a descobrir. São Paulo:ASA/Cortez,1997

UNESCO. World Education Forum 2015 Report. Disponível em: 
http://unesdoc.unesco.org/images/0024/002437/243724e.pdf> Acesso em: 10 de nov. 2019 VYGOTSKY, Lev. S. A formação social da mente. São Paulo: Martins Fontes, 1998. 


\section{Capítulo 8}

doi $10.37423 / 210704437$

UMA ANÁLISE DAS CRÔNICAS DE AUTORIA DE MARTHA MEDEIROS E LYA LUFT SOBRE A MULHER CONTEMPORÂNEA 
Resumo: A crônica é um gênero literário que comumente oscila entre o jornalismo e a literatura. Está presente em revistas e jornais, narrando, relatando, descrevendo e até argumentando com efemeridade acontecimentos e ao mesmo tempo, expressando os pensamentos daqueles que "enxergam" com sensibilidade o cotidiano aos mínimos detalhes. A ideia é fazer uma análise literária sobre os textos de duas escritoras brasileiras conceituadas pela crítica no Brasil, em relação a crônicas. Trata-se de Martha Medeiros, nascida em Porto Alegre, Rio Grande do Sul e Lya Luft, nascida em Santa Cruz do Sul, também, no Rio Grande do Sul, esta última teve grande parte de seus textos publicados na revista semanal Veja. A problemática é: qual o "olhar" destas autoras sobre a mulher contemporânea? Como elas abordam sobre o feminino na contemporaneidade? O objetivo geral é analisar a figura feminina na contemporaneidade expressas nas crônicas destas duas autoras. Os objetivos específicos são: fazer um breve estudo teórico sobre a crônica na atualidade escrita por mulheres brasileiras no contexto da literatura contemporânea e observar a linguagem utilizada nas crônicas que expressam opiniões sobre a mulher na atualidade. A metodologia foi bibliográfica e documental, pois se utilizaram livros da crítica literária sobre crônica, contemporaneidade, assim como, documental porque se utilizaram os textos das autoras supracitadas. Entende-se que este trabalho é importante para os estudos de autoria feminina na literatura contemporânea e servirá como início de mais estudos aprofundados sobre a área.

Palavras-chave: Crônica de autoria feminina, mulher contemporânea, literatura contemporânea. 


\section{INTRODUÇÃO}

Historicamente, o termo crônica, esteve ligado à questão do tempo, seja relatando eventos, fazendo narrações, descrições, argumentações presentes nas palavras de jornalistas e escritores.

Destaca-se que durante séculos, somente os homens tinham espaço nos jornais e revistas literárias para expor pensamentos, narrações, descrições, injunções acerca da vida cotidiana. Não se via espaços privilegiados para a escrita feminina nos periódicos. O espaço da mulher, como destaca Silva (2010) estava longe dos grandes temas, ou então, era uma "imitação da literatura masculina", pois isso estava internalizado no imaginário coletivo e produzido nas práticas socioculturais.

Seguindo esta linha de raciocínio, este artigo científico visa discutir sobre o gênero híbrido literáriojornalístico (crônica), sob o vieis da escrita feminina de duas autoras brasileiras: Martha Medeiros e Lya Luft. Ambas são oriundas do Estado do Rio Grande do Sul - RS e são de gerações diferentes. Elas escrevem em jornas e revistas brasileiras e já publicaram vários livros de romances e crônicas. Partirse-á dos textos escritos por estas autoras quando abordam em suas crônicas aspectos diretamente relacionados ao ser feminino no contexto da contemporaneidade, isto é, entre fins do século XX e início do século XXI.

A problemática apresentada aqui se debruça sobre o seguinte questionamento: qual o olhar das escritoras supracitadas sobre a mulher contemporânea, considerando-se o fato de que as mulheres desta geração, de um modo geral, deixaram de transitar no cotidiano, como meras 'donas de casa', que só cozinhavam, passavam e tomavam conta dos filhos, para serem as mulheres que trabalham fora de casa e dão conta destes mesmos afazeres domésticos citados. A proposta deste estudo considera importante destacar o fato de que a escrita feminina muitas vezes esteve 'taxada' na própria literatura brasileira, como 'literatura açucarada', de pouca presença no contexto de se expressar aspectos filosóficos ou de cunho universal.

Nas palavras de Silva (2010, p. 35):

Uma vez que as mulheres só tinham acesso ao mundo doméstico, particular, privado [...] sobre que assuntos poderiam discorrer [...] se estavam longe dos grandes acontecimentos, distantes dos espaços propiciadores de experiências coletivas, privadas.

Martha Medeiros e Lya Luft, duas mulheres pensantes no Brasil, que questionam comportamentos, atitudes, políticas, religiões, economias, comunicações, tecnologias, mídia, saúde, empresariado, 
enfim, uma infinidade de temas cruciais da sociedade. Como elas abordam sobre o feminino nesta contemporaneidade?

Partindo deste pressuposto, o objetivo central desta pesquisa é analisar a figura feminina nas crônicas das autoras supracitadas. Os objetivos específicos são: fazer um breve estudo sobre o conceito de crônica com base do pensamento de Moisés (2012) e Pereira (2004) e, por último, observar a linguagem utilizada por Martha Medeiros e Lya Luft quando expressam opiniões sobre a mulher na atualidade.

Acredita-se que a partir destas reflexões, seja possível configurar e problematizar a questão do modo de ver o cotidiano sob a ótica da escrita feminina em textos do gênero crônica.

Metodologicamente, considerou-se que este trabalho é de caráter bibliográfico e documental, pois se trata de um recorte sobre o conceito de crônica, assim como documental, porque se utilizaram as próprias produções jornalístico-literárias das autoras em estudo. Entende-se que esta pesquisa é um estudo embrionário, pois se pretende aprofundar ainda mais tal temática em estudos futuros na academia.

\section{BREVES ABORDAGENS SOBRE O GÊNERO CRÔNICA}

A crônica nasceu sob o signo da palavra grega Cronikós relativo a 'tempo' Chrónos, pelo latim Chronica, designando no início da era cristã, como uma lista ou relação de acontecimentos ordenados segundo a marcha do tempo, a uma sequencia cronológica (MOISÉS apud PEREIRA, 2004).

Além da questão do tempo, nas crônicas, há a presença de interpretações dos fatos narrados, analisando vários temas em tom efêmero e, ao mesmo tempo, profundo. Percebe-se, que também, há em determinados textos da crônica, uma carga maior de conotação, assim como, de aspectos denotativos.

Cândido (apud CARLAN, 2012, p.35) no Brasil, diz: "a crônica nasceu como folhetim, um artigo de rodapé sobre as questões do dia". Pereira (2004) mostra que a noção de crônica também passou pelo aspecto do relato histórico, depois como acessório do ensaio, enfim, o gênero crônica estabelece-se sempre no 'entremeio' de um outro gênero, quer seja literário, quer jornalístico.

Modernamente é a Montagne, com Essais (1856), que se deve a iniciação do gênero, novamente como o sentido etimológico da palavra que indica: tentativa, inacabamento, experiência, dissertação curta e metódica sem acabamento sobre assuntos variados em tom íntimo, coloquial, familiar [...] (COUTINHO apud PEREIRA, 2004, p. 19). 
No século XIX, a crônica torna-se alvo de reflexões sobre verdadeiramente qual seria o seu conceito, e diante da sua semelhança com o ensaio, alguns estudiosos seguiram o raciocínio de Montaigne, outros, decidiram classificá-la como um gênero transitório que ora se apresentava mais próxima do ensaio, por conter a linguagem dos bacharéis de Direito, ora como um acessório do ensaio.

Pereira (2004, p.29) retoma estas abordagens e dispara: “A crônica não tem independência estética. Portanto, quando a classificam, eles produzem conceitos híbridos, cuja valoração semântica se dá a partir da forma discursiva que prevalece no texto de determinados cronistas".

Neste sentido, a crônica guarda em si mesma um conceito híbrido, pois ela é uma conjunção de elementos linguísticos que apresenta expressões verbais características do assunto discutido e dos novos significados construídos a partir de narrações, descrições, argumentações, entre outras.

Seja no contexto do jornalismo ou da literatura, a crônica estabelece-se em novos processos de enunciação, transformando-se em um espaço textual que absorve, criticamente, várias linguagens (PEREIRA, 2004).

É interessante destacar, também, algumas considerações sobre a crônica de acordo com Jésura Lopes Chaves, em que fez um texto intitulado "Compreensão leitora e estrutura argumentativa no gênero crônica:

A crônica atua como portadora do espírito do tempo, tanto por suas características formais como por seu conteúdo, pela relação que nela se instaura entre ficção e história, pelos aspectos aparentemente casuais do cotidiano, como também pela complexa trama de tensões e relações sociais que entremeiam sua composição. Importante ainda é cumplicidade lúdica que se estabelece entre o autor e o leitor, sempre ancorada na contemporaneidade (CHAVES, 2009, p.36).

A crônica contém aspectos chamativos, emocionais e, ao mesmo tempo racionais sobre fatos do cotidiano e aquele quem a produz extrai deste mesmo cotidiano, elementos que sensibilizam o leitor, desde o título, a introdução, o desenvolvimento e as considerações finais da mesma.

Carlan (2012, p. 35) mostra em seus estudos a razão pela qual os jornais brasileiros gostam de publicar crônicas:

Um dos modos de fazer com que o leitor sinta-se mais presente no texto e no universo retratado por ele é a publicação de crônicas. Nelas, o autor não só apresenta um fato ocorrido, como também esclarece o leitor sobre o assunto. A crônica está entre os gêneros jornalísticos opinativos. É possível aproximá-la da esfera do literário. 
A crônica, enfim é um gênero que deve ser analisado pelos pesquisadores de várias áreas, sobretudo, da comunicação e das letras, pois ela foi gerada dentro dos dois universos profissionais.

\section{MARTHA MEDEIROS E SUA OBRA}

Martha Medeiros é gaúcha, nascida em Porto Alegre no dia 20 de agosto de 1961. É formada no curso de Comunicação Social, e atuou durante os primeiros anos de sua carreira na área de Publicidade e Propaganda, como redatora e diretora de criação em diversas agências da capital do Rio Grande do Sul.

Ao lado da carreira profissional como publicitária, Martha Medeiros se identificou bastante com o ofício de escritora, tanto que, chegou a publicar em 1985, seu primeiro livro de grande sucesso de vendas "Streap tease" pela editora L \&PM, depois, não parou mais e seguiu com "Meia noite e um quarto", em 1987; "Persona non grata”, em 1991. Até que em 1993, Martha Medeiros decidiu se dedicar mais profundamente à produção literária, indo morar na cidade de Santiago, no Chile a fim de se debruçar ainda mais com a literatura, escrevendo textos literários, entre poesia, crônicas e romances.

De acordo com Carlan (2012, p. 46):

Quando voltou para o Brasil, ainda em 1993, Martha Medeiros começou a colaborar com crônicas para o jornal 'Zero Hora', de Porto Alegre, em que até hoje mantém uma coluna no caderno Donna, que circula aos domingos, e outra - às quartas-feiras - no segundo Caderno. A cronista escreve atualmente também uma coluna semanal veiculada aos domingos para o caderno Revista 'O Globo', do Rio de Janeiro.

Desta forma, Martha Medeiros dá início à escrita e produção de seus livros literários de poesias no país, de acordo com o site da sua editora L\&PM: "De cara lavada", 1995; "Poesia reunida", 1999; "Cartas extraviadas e outros poemas", de 2001. A autora em 1995 publicou também, seu primeiro livro de crônicas pela editora Artes e Ofícios, "Geração bivolt", resultado de artigos publicados no jornal "Zero Hora", além de textos inéditos. Em 1996, também publicou "Santiago do Chile - Crônicas e dicas de viagem", relatando os oito meses em que vive na capital do Chile, Santiago.

Destaque-se, também, que o livro "Topless", publicado em 1997, ganhou o prêmio Açorianos de Literatura. A publicação reuniu 54 crônicas em uma amostra do trabalho que a consagrou como uma das mais importantes cronistas em atividade no Brasil.

Outro prêmio de grande importância foi com outro livro de crônicas chamado "Montanha- russa", lançado em 2003, que ganhou o segundo lugar no Prêmio Jabuti e também vencedor do Prêmio 
Açoiranos. Neste livro, as crônicas foram, em maior parte publicados pelo jornal "Zero Hora" e pelo site "Almas gêmeas", entre setembro de 2001 e agosto de 2003.

Das 26 (vinte e seis) publicações de Martha Medeiros, 13 (treze) são livros de crônicas.

Neste sentido, observa-se a importância que a autora dá à sua produção de crônicas.

Carlan (2012) comenta que o livro de crônicas "Trem-bala" é o best-seller do gênero crônica e, que, inclusive, foi adaptado, com sucesso, para os palcos, sob direção da gaúcha, atriz e diretora Irene Brietzke. "O livro reúne mais de uma centena de textos de Martha Medeiros. Neles, a autora reflete sobre o que querem as mulheres, sobre relacionamentos virtuais, o fim da paixão nos tempos modernos, seus escritores, livros e neuras preferidas" (IBDEM, 2012, p.47).

\section{LYA LUFT E SUA OBRA}

A escritora Lya Feft Luft, nasceu na cidade de Santa Cruz do Sul, município de colonização alemã localizado no Rio Grande do Sul. Lya nasceu em 15 de setembro de 1938.

Em 1959, foi morar na capital rio-grandense do sul, Porto Alegre, e lá se graduou tanto em Pedagogia como em Letras Anglo-Germânicas pela Pontifícia Universidade Católica do Rio Grande do Sul (PUCRS). Trabalhou como tradutora de literatura alemã e inglesa.

Iniciou sua carreira literária em 1964, com a coletânea "Canções de limiar". Em 1972 publicou seu segundo livro de poemas, "Flautas Doces". Em seguida, já quatro anos após, escreveu contos e lançou em 1978, sua primeira coletânea de contos, "Matéria do Cotidiano". Daí em diante não parou mais e escreveu vários livros, resultam em 28 (vinte e oito) publicações.

A autora Lya Luft já revelou que sua produção literária é um processo de criação de histórias e personagens.

Se escrevo sobre a vida com seus encontros e desencontros, também falo de homens e mulheres. Minhas interrogações provavelmente não têm resposta adequada, como a maior parte das coisas desta vida nossa - por isso mesmo material inesgotável para a arte. [...] não escrevo com doçura, adjetivo atribuído a textos de mulheres, e não busco compor meu texto com vigor de homem. Escrevo com o vigor de uma mulher (LUFT apud FARIA, 2003, p. 129).

Em todas as suas produções literárias, seja na poesia, na crônica e nos romances, Lya Luft se destaca por utilizar uma linguagem madura sobre o cotidiano, baseada nas experiências de vida da própria escritora. 


\section{MULHER CONTEMPORÂNEA}

Neste estudo, tomou-se como corpus, a coletânea de crônicas da autora Martha Medeiros "TremBala". Ressalte-se que as crônicas foram também publicadas nos jornais O Globo e Zero Hora. Ao todo, o livro é composto de 112 (cento e doze) crônicas, só que destas 112 (cento e doze), extraíram-se 20 (vinte) crônicas em que relatavam especificamente opiniões sobre a figura feminina nos dias atuais. Dentro destas 20 (vinte) crônicas, foram selecionadas duas crônicas como forma de ilustrar analiticamente a linguagem utilizada para abordar sobre a mulher contemporânea na visão de Martha Medeiros.

Desta forma, além desta pesquisa ser bibliográfica e documental, caracteriza-se, também, em ser qualitativa, pois tomou um corpus menor para realização das análises de forma mais profunda e interpretativa.

O quadro abaixo ilustra os 20 (vinte) títulos mais relacionados diretamente a discussões sobre a mulher de um modo geral. Títulos das crônicas do Livro "Trem-Bala", de Martha Medeiros que abordaram diretamente sobre a mulher na contemporaneidade.

\section{QUADRO C}

\begin{tabular}{|l|}
\hline 1. As boazinhas que me perdoem \\
\hline 2. O que quer uma mulher \\
\hline 3. Parto sem dor \\
\hline 4. Mulher de um homem só \\
\hline 5. Mulheres de preto \\
\hline 6. Homens X Mulheres: empate técnico \\
\hline 7. Cordão Umbilical \\
\hline 8. Atrasados e orgulhosos \\
\hline 9. Sozinha no restaurante \\
\hline 10. O sexo da mães \\
\hline 11. Mil vezes Clarice \\
\hline 12. Mulheres como vieram ao mundo \\
\hline 13. O homem e a mulher da sua vida \\
\hline 14. Mamãe Noel \\
\hline 15. Dia Internacional da porção mulher \\
\hline 16. O Mulherão \\
\hline 17. A noite das mães \\
\hline 18. O jogo da velha \\
\hline 19. Ilha dos lobos \\
\hline 20. Relacionamentos maduros \\
\hline
\end{tabular}

FONTE: (MEDEIROS, 2012) 
Com relação ao corpus de Lya Luft, utilizaram-se os textos extraídos diretamente da Revista semanal brasileira VEJA em que a figura feminina estava diretamente mencionada dentro do texto. Escolheuse diretamente o semanário VEJA para a realização da pesquisa pelo fato de se perceber que autora reservou em seus textos homenagens ao poder do feminino. Abaixo, seguem os títulos e as datas de publicação das mesmas, no semanário VEJA:

\section{QUADRO D}

\begin{tabular}{|l|}
\hline 1 Setenta anos, por que não? (VEJA, 17 set. 2008) \\
\hline 2 A mulher e o poder (VEJA, 28 jan. 2009) \\
\hline 3 A mulher limpinha (VEJA, 24 nov. 2010) \\
\hline 4 Por que os homens nos matam (VEJA, 21 jun. 2010) \\
\hline 5 A mãe natureza e a mãe pátria (VEJA, 18 jan. 2012) \\
\hline
\end{tabular}

FONTE: (VEJA 2008-2012)

Ao todo, foram 02 (duas) crônicas analisadas da coletânea de 112 (cento e doze) crônicas "Trem-Bala", escrita por Martha Medeiros: "As boazinhas que me perdoem"; "O que quer uma mulher".

A crônica "As boazinhas que me perdoem", destaca-se pela linguagem autêntica, direta e clara da autora. Não é por acaso que é a primeira do livro: "Trem-Bala". A autora inicia seu texto com duas problemáticas a serem argumentadas detalhadamente. Uma sobre qual o elogio que toda mulher adora receber e outra, sobre o que faz uma mulher detestar escutar.

Em um único parágrafo, Martha Medeiros utiliza a linguagem coloquial personificando-se no discurso da mulher contemporânea como aquela que gosta de ser elogiada em todos os sentidos, desde os físicos ou morais, o que não se tolera é escutar o adjetivo diminutivo "boazinha" originado de outros adjetivos diminutivos como "queridinha, pequenininha, educadinha, ceguinhas".

Se a mulher dos séculos passados "engolia tudo", "fingia" e "vivia rodeada de panelinhas e nenezinhos", a mulher contemporânea que Martha Medeiros aborda é uma outra completamente diferente e alheia a tais adjetivos. A autora associa o vocábulo "boazinha" a "coitadinha", "comportadinha", sempre "disponível, serena, previsível, nuca foi vista negando um favor".

Para a autora, a mulher de hoje é uma mulher de atitudes velozes, que odeia ser chamada de "boazinha". A mulher atual é uma mulher "bacana, complicada, batalhadora, persistente, ciumenta, apressada". 
A própria autora, em sua crônica, insere-se no discurso, utilizando a 1a (primeira) pessoa do plural (nós) e afirma: "é isso que somos hoje. Merecemos adjetivos velozes, produtivos, enigmáticos. As "inhas" não moram mais aqui. Foram para o espaço, sozinhas" (MEDEIROS, 2012, p. 12).

Neste sentido, percebe-se que o olhar da autora sobre o feminino no contexto do contemporâneo, é de que a mulher é um ser imperfeito e complicado e, por outro lado, batalhador e persistente.

Na crônica "O que quer uma mulher", Martha Medeiros discute o paradoxo do pensamento feminino. Ao mesmo tempo em que a mulher contemporânea é este ser veloz, "até as mais modernas e cosmopolitas têm o sonho secreto de encontrar um príncipe encantado".

Em outras palavras, argumenta-se que toda mulher deseja ser "resgatada da torre do castelo [...] ouvir eu te amo só no ultimo capítulo". E nesta busca na qual a autora discute, nem sempre o homem consegue corresponder à expectativa de uma mulher, pois "nenhuma mulher se sente amada o suficiente".

Com esta última oração, a autora desfecha sua crônica demonstrando o caráter completo da mulher contemporânea, imerso em uma encruzilhada: de um lado, é uma mulher veloz, de outro, uma mulher que busca o amor a todo custo.

Na leitura de apenas duas crônicas, observa-se que a abordagem sobre a mulher contemporânea na visão de Martha Medeiros é de uma mulher com atitudes corajosas, que está sempre buscando a felicidade e a liberdade, mas também quer ser amada por um "príncipe encantando".

As duas crônicas analisadas de Lya Luft foram extraídas da revista semanal brasileira VEJA, e são datadas dos anos de 2008 e 2009. De uma maneira geral, percebe-se que o texto de Lya Luft trata também sobre o feminino em situações diversas.

Na crônica "Setenta anos, por que não?", (2008), a autora aborda a questão do tempo, dos anos corridos, da velhice. Percebe-se que a autora insere-se na crônica utilizando a primeira pessoa (eu), e também, expressões como "a gente", o pronome oblíquo (me) para argumentar, comentar sobre a temática discorrida.

Logo no início da crônica ela se insere no texto:

Se a gente (grifo nosso) considera uma ladeira que desce a partir da primeira ruga, ou do começo da barriguinha, então viver é de certa forma uma desgraceira que acaba na morte [...] O tempo me (grifo nosso) intriga, com tantas coisas, desde que eu (grifo nosso) tinha 5 anos (VEJA, 2008, p. 26) 
A autora aborda sobre a mulher contemporânea de seus 70, 80, 90 anos comentando que se vive em outro momento, diferente daqueles vividos por mulheres de outras épocas.

Pois se minhas avós eram damas idosas aos 50 , sempre de livro na mão lendo na poltrona junto à janela, com vestidos discretíssimos, pretos de florzinha branca [...] hoje aos 70 anos estamos fazendo projetos, viajando (pode ser simplesmente à cidade vizinha para visitar uma amiga), indo ao teatro e ao cinema, indo ao restaurante (pode ser o de quilo, ali na esquina), eventualmente namorando ou casando de novo. Ou dando risada à toa com os netos, e fazendo uma excursão com os filhos. Tudo isso sem esquecer a universidade, ou aprender a ler [...] (VEJA, 2008, p. 26).

Observa-se que a autora inseriu-se mais uma vez no discurso da própria crônica para se personificar nesta mulher contemporânea madura, que vive numa época onde se permite namorar, comer fora, viajar com amigas, casar de novo. Esta inserção encontra-se no pronome possessivo "minhas avós" e "hoje aos 70 anos estamos fazendo projetos...".

Em outra crônica intitulada "A mulher e o poder" (2009), Lya Luft reflete sobre a relação do poder no universo do feminino, já que escrever sobre poder e o masculino para ela, já se trata de um óbvio "ululante".

Nesta crônica, a autora mostra que a mulher contemporânea está ocupando cargos de poder diversos:

Não faz tanto tempo que começamos assumir funções de ministra, prefeita, governadora, cientista, motorista de táxi e ônibus, reitora, e tantos outros. Não fôramos preparadas para enfrentar esse amigo/inimigo, o poder. Sendo pioneiras, e sem modelos a seguir, a quem deveríamos recorrer, em quem nos inspirar à frente do país? [...] Restava-nos a imagem dos homens (VEJA, 2009, p. 22).

O foco de discussão desta crônica é que o poder existe e saber administrá-lo é algo que homens e mulheres precisam saber para serem destruídos por ele. A autora busca respostas sobre como exercer o poder, indagando se existe um "jeito feminino de exercer o poder" já que o poder sempre esteve sob controle do sexo masculino.

A reflexão final da crônica é que o ser humano, seja do sexo masculino ou feminino, é frágil, tem defeitos e precisa ter cuidado ao manusear com o poder. A autora mais uma vez insere-se no discurso, utilizando a 1a (primeira) pessoa do singular, não somente por ser uma mulher, mas, um ser humano.

Talvez seja apenas um jeito humano, pois é o que todos somos: cheios de fragilidade e força, de qualidades e defeitos, todos em última análise com medo de não ser atendidos. [...] ser apenas uma pessoa a quem o poder foi dado pela sorte, pelo destino, pelo mérito (o melhor de todos), por algum concurso, enfim, pelos caminhos da profissão, e tentar fazer isso da melhor forma possível (VEJA, 2009. p. 26). 
Lya Luft coloca, neste sentido, que o poder deve ser exercido da melhor forma possível, sem sectarismos de sexos, feminino ou masculino. Observa-se, então, que a autora opta por uma visão da mulher e do homem como seres humanos frágeis e que precisam agir com "simplicidade, lucidez e autocrítica" diante do exercício do poder.

\section{CONSIDERAÇÕES}

Nesta breve análise das crônicas de Martha Medeiros e Lya Luft, percebe-se dois olhares femininos. Martha Medeiros utiliza-se de uma linguagem direta e coloquial, típica da mulher contemporânea, como forma de se personificar numa mulher corajosa, que diz o que pensa, busca a felicidade e a liberdade, mas, paradoxalmente, quer ser amada e raptada por um "príncipe encantado" que lhe diga palavras de elogio, apesar dela mesma ser tão complicada.

Lya Luft, em outra dimensão do feminino, mais madura e serena, mostra-se como a mulher que mesmo aos 70, 80 ou 90 anos, não se deixa abandonar pela velhice, e vive intensamente sua existência fazendo o que mais lhe dá prazer, seja viajando, indo a restaurantes, curtindo seus netos, sem tanta seriedade, sem cobranças nem críticas. Mulheres e homens têm defeitos e qualidades, são frágeis, mas o que importa é a naturalidade e fazer tudo da melhor maneira possível, sendo éticos e humanos.

A partir desta breve análise, observou-se como o gênero crônica permeia entre a literatura e o jornalismo, pois ao mesmo tempo, em que se realizou a contemplação da vida de mulheres, também se realizou uma reflexão sobre o pensamento feminino como uma forma de opinião, que faz parte também do fazer jornalístico. 


\section{REFERÊNCIAS}

CANDIDO, Antônio. A vida ao rés-do-chão. In: CANDIDO, Antonio (org). A crônica: o gênero, sua fixação e suas transformações no Brasil. Campinas, SP: Ed. da UNICAMP, 1992.

CARLAN, Letícia Amaral. O Sujeito comum nas crônicas de Martha Medeiros. Dissertação de mestrado. Porto Alegre: PUCRS, 2012.

CHAVES, Jésura Lopes. Compreensão leitora e estrutura argumentativa no gênero crônica. In:Letrônica, v. 2, n. 1, p. 91-104, julho 2009.

COUTINHO, Afrânio. A literatura no Brasil. São Paulo: GLOBAL, 1999.

GUARACIABA, Andrea. "Crônica”. In: MELO, José Marques de. Gêneros jornalísticos na Folha de São Paulo. São Paulo: EDUSP, 1987.

MOISÉS, Massaud. A criação literária - Prosa. São Paulo: Cultrix, 1978.

Pequeno dicionário da literatura brasileira. São Paulo: Cultrix, 1986. MEDEIROS, Martha. Trem-bala. Porto Alegre: L\& PM, 2012.

MENEZES, Raimundo de. Dicionário literário brasileiro. 2ae ed. Rio de Janeiro: LTC, 1978.

PEREIRA, Wellington. Crônica: a arte do útil e do fútil - ensaio sobre crônica no jornalismo impresso. Salvador, BA: Calandra, 2004. Coleção Biblioteca J;2.

SILVA, Antônio de Pádua Dias da. Mulheres representadas na literatura de autoria feminina: vozes de permanência e poética da agressão. Campina Grande: EDUEPB, 2010. 